ISSN 1691-5348

Indexed in EBSCO, Copernicus

\title{
JOURNAL
}

OF BUSINESS

MANAGEMENT

\section{VOLUME 19}

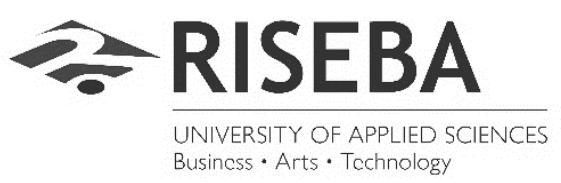




\section{The Editorial Board}

\section{Head of the Editorial Board}

Dr. Tatjana Vasiljeva, RISEBA University of Applied Sciences, Latvia

\section{Editors}

Dr. Bella Butler, Curtin University, Australia

Dr. Andrejs Cirjevskis, RISEBA University of Applied Sciences, Latvia

Dr. Ole Gjolberg, University of Life Sciences, Norway

Dr. Ulla Hytti, University of Turku, Finland

Dr. Daiga Kamerade-Hanta, University of Salford, Great Britain

Dr. Inna Kozlinska, University of Groningen, Netherlands

Dr. Tonis Mets, University of Tartu, Estonia

Dr. Drahomira Pavelkova, Tomas Bata University of Zlin, Czech Republic

Dr. Sean Patrick Sassmannshausen, Regensburg University of Applied Sciences, Germany

Dr. Arnis Sauka, Stockholm School of Economics in Riga, Latvia

Dr. Irina Sennikova, RISEBA University of Applied Sciences, Latvia

Dr. Marina Solesvik, Western Norway University of Applied Sciences, Norway

Dr. Tatjana Volkova, BA School of Business and Finance, Latvia

Production Editor Dr. Vulfs Kozlinskis

Technical Editor Mg. Anna Strazda

Language Consultant Dr. Benjamin Breggin 


\section{Foreword}

In 2020, a wide range of papers was received. All the papers were double-blind peer reviewed. Following the necessary corrections and additions resulting from the review process, six accepted papers were included in the issue.

For instance, the authors of the paper "Work, profit and dignity: Towards an integrative HRM paradigm" analysed two existing paradigms in human resource management. The authors' conception that "an integrative model of management, including social theory of labour, is needed" could be the starting point of integrity research. Interesting conclusions were made about the tendencies of development of a new paradigm in connection with the pandemic.

A topic of growing importance was addressed in the paper "In search of high-performance workplace factors among SMEs". Creation of high-performance workplaces in SMEs could be a means of economic recovery after the pandemic.

To protect academic integrity and prevent ethical issues, all submissions were automatically screened by the software Ouriginal (combined expertise of Urkund and PlagScan's plagiarism detection solution).

The Journal of Business Management has been indexed in COPERNICUS since 2017 and in EBSCO since 2008.

Tatjana Vasiljeva

Prof, Dr. oec.

Chief Editor 
All rights reserved. No part of this publication may be reproduced, stored in a retrieval system, or transmitted in any form or by any means, electronic, mechanical, photocopying, recording or otherwise, without the prior written permission of the publisher.

\section{Contents}

Work, profit and dignity: Towards an integrative HRM paradigm

BARBARA MAZUR,_MARTA MAZUR-MALEK .5

In search of high-performance workplace factors among SMEs

JANIS GERCANS .20

Role of informal institutions in the relationship between social capital and international entrepreneurial entry

MUHAMMAD UMER SHAHID 39

The challenges of cybersecurity insurance development: The case of Latvia TATJANA VOLKOVA, LINDA JEKABSONE, ZITA LAVRINOVICA, ELINA SABA, MARIS SABA

Financial sector reform (2016-2019): The impact on Latvian banks JEKATERINA SNEIDERE, IVARS GODMANIS .80

An analysis of factors affecting the performance of supplier SMEs JANIS GERCANS, SANDIS BABRIS 100

Authors 124

Editorial Affiliation Details 128 
Received: 26 July 2020

Accepted for publishing: 6 January 2021

DOI: $10.32025 / J B M 19001$

\title{
Work, profit and dignity: Towards an integrative HRM paradigm
}

\author{
BARBARA MAZUR \\ MARTA MAZUR-MALEK
}

\section{ABSTRACT}

Purpose. The main purpose of this article is to present two opposing paradigms of management economic and humanistic - and to indicate the sources and consequences of their dissimilarities.

Methodology. This article is conceptual in nature. It is based on a literature review. During the research, a comparative analysis was carried out to sort out the differences in the definitions of labour in economics and sociology.

Findings. Economics and sociology have different understanding of labour. This difference is significant and gives birth to two opposing paradigms of HRM management. The dominant paradigm is the economic one, which does not take into account the humanistic nature of man. Therefore, an integrative model of management, including social theory of labour, is needed.

Research limitation and directions for future research. The article presents work in its historical aspect. It does not show how the pandemic contributes to the concept of work and changes it. Investigating whether remote work is the next step in the evolution of the concept of work might indicate the direction of future research.

Practical implications. The integrative approach ensures employees the achievement of material (financial) well-being and social well-being (social relations based on respect for dignity). This could prevent negative organizational behaviour such as mobbing or work-related phenomena such as occupational burnouts.

Originality/value. The paper is a conceptual article investigating how the notions of labour in economics and sociology influence the economic and humanistic paradigm of management. It also makes an original contribution regarding the impact of the COVID-19 pandemic on HRM methods.

Keywords: labour, economic/non-economic action, economic/humanistic HRM 


\section{INTRODUCTION}

Work is central to everyone's life. It is a source of income, enables the implementation of life plans and goals, facilitates one's own development, provides a sense of security, and is sometimes the meaning of life. In a market economy, labour becomes a complex and diverse action. Due to globalization and digitalization, the forms of labour are changing. In these circumstances it is important to rethink the understanding of labour, particularly in economics and sociology, and find out the consequences of these different understandings for business.

The main problem addressed in this paper is whether labour as an economic action is enough for companies to succeed in the modern market or whether an idea of a job as a non-economic action is needed as well. The subject of this article lies on the borderline between economics and sociology. That is why there is a need to know how labour is defined in these disciplines, i.e. neoclassical economic theory and sociology. The other point is to understand what an economic action and a non-economic action are and how both could be applied to the paradigm of management. The words 'work' and 'labour', though they are not entirely synonyms and have their own meanings, will be used interchangeably for the sake of the article.

\section{Work in a historical perspective}

From ancient times to the Middle Ages, labour and productive activity were seen as below the dignity of a free man. Work was done by slaves and craftsmen under duress. The ideal way of life was to do little or no physical work. However, despite the universality of this ideology, the first church fathers (John Chrysostom, Basil of Caesarea, Ambrose, Irenaeus) did not share the opinion that work was opus servile. On the contrary, they believed work to be opus humanum. They had a vision of work that would honour a man, correspond to his dignity, express this dignity and even increase it (Pirson et al., 2016).

In the late Middle Ages, there was a significant controversy between the clergy and the Mendicant orders (Franciscans, Dominicans) regarding the attitude towards physical labour. New views on the role of work and its place in human life emerged at the time (Sison, 1992). Any productive activity that engaged the entire human being - not only the body, but also the soul and reason - began to be regarded as work, according to the term 'opus humanum'. In this way, work gained access to the sphere of dignity to such an extent that it was recognized as a 'human act', an activity of a rational and free person which reflected his intrinsic value.

In this new approach, a working person begins to identify with his work, transferring his inner dignity onto it as onto something personal and as onto the property of the one who performed the act. During this period, work obtained an instrumental value (bonum utile), which was not an autotelic value in itself. Thomas Aquinas highlighted three instrumental 
values of work: avoiding idleness, equipping people with higher skills and obtaining means of subsistence. Given the reasons above, work was considered an element of natural law, not just a divine recommendation.

These three instrumental values reflect the developmental, dynamic aspect of human dignity. Human dignity reaches its fullness by working and thanks to work. Therefore, work is a human vocation: man expresses himself through work; humanity is fulfilled through work and because of work.

In the concept of Thomas Aquinas, there are differences between natural moral principles, some of which result from community needs, others from individual needs. The work done to obtain resources necessary for subsistence responds to collective needs. Work creates a common good. When a departure from physical labour is observed - for example in the case of children, disabled people, the elderly, Mendicant orders - intellectual work appears. This is a step forward in creating a reputation for work as being closely related to human dignity (Sison, 1992).

The process of raising the status of work and including intellectual work in the concept of human labour (as related to dignity) was halted during the Reformation. Luther undermined the legitimacy of Mendicant monasteries. In his opinion, the monks should work like all other people, not only to earn a living, but also for their own salvation. According to him, the duty of manual labour applied to everyone without exception. To this interpretation of work, Calvinists added that success at work is evidence of God's grace and predestination. Such an understanding of work undermined the previous conviction of spirituality's superiority over physical work. It also undermined the superiority of autotelic values, which are goals in themselves, over instrumental values directly related to work. In the approach adopted by the Reformation, instrumental values prevailed (Sison et al., 2016). A return to the issue of human labour could once again be observed at the end of the 19th century, when the Catholic Church defended workers' rights (Encyclical of Leo XIII, 1891). A departure from the traditionally accepted perspective of work morality towards work theology took place (a possible approach to God through work). The obligation to work and the right to work are inherent in human nature. People express themselves and increase their dignity through work.

In the European tradition, dignity is perceived in the post-Kantian perspective as an inalienable quality of a human being regardless of race, sex, age, social status, ethnicity or nationality. Kant claimed that there are things that have no price but have value in themselves. Dignity is such a feature. Kant believed that only human beings had dignity. Thus, dignity in a broad understanding can only be human. 


\section{The notion of labour in economics and sociology}

Nowadays labour is a complex notion. In this part of the paper, an attempt will be made to verify whether the notions of labour are alike in sociology and economics and determine the problems and possibilities of the definitions of labour in both of these sciences.

From the sociological point of view, talking about labour is talking about the relationships between employers and workers. These relationships may be organized both in the form of "paid employment" and in the forms of "unpaid, voluntary, and forced labor" (Elger, 2006). It is significant that all these forms of labour can be understood within the framework of different paradigms, such as Marxist, capitalist or institutionalist.

The economic view on labour recognizes human beings as factors of production (Rogozhnikova, 2018). Consequently, a short excursus on the theory of human capital to clarify the economic view on labour is needed. G. Becker, a co-founder of the theory of human capital, gave a broad interpretation of capital as not only labour and land, but also schooling, computer training courses, medical care expenditures, and lectures on the virtues of punctuality and honesty. These constitute human capital because people cannot be separated from their knowledge, skills, health, or values in the way they can be separated from their financial and physical assets (Becker, 2008). T. Schultz expressed this thought in a very significant phrase: the "economic value of man" (Schultz, 1972). He emphasized a "strictly economic" essence of the theory of human capital. That is, human capital is broader than just labour, because it includes some aspects behind the labour process: preparation for labour, further training, private medical insurance and the like.

This view on capital was all new to both classical and neoclassical economics. The theory of human capital, originally innovative, was simplified by neoclassical economics. This simplification consisted of the assumption that earning on human capital had become more important than investing in it.

When comparing sociological and economical definitions of labour, the following conclusions can be drawn:

- The sociological definition of labour reveals itself through the analysis of the relationships between the parties involved in the labour process. This approach allows one to trace different changes in the organization of the labour process and in understanding it, caused by changes in society and in paradigms of understanding labour itself.

- The modern economic view on labour defines it by referring to the theory of human capital. The human capital theory includes phenomena which get their specific economic value when they become elements of the labour process and by way of evaluating this process. This theory changed the human's view of himself, placing an individuum in the centre of the labour process as a commodity. Society is all products, not persons. People / products have a price tag; having a price, they lose the dignity which is priceless. 


\section{Labour as an economic and non-economic action}

Work means taking specific actions. An action is defined as a purposeful, conscious and responsible operation: physical or mental. Since labour has an economic understanding as a prevailing one, we define it as an expedient activity of economic value production using our knowledge and skills.

Work can be interpreted as an economic or non-economic action. To explain the difference between these meanings, the question of the difference between economic and social aspects of reality, or how economic and social aspects relate to each other, must be answered (Rogozhnikova, 2018). There may be at least three points of view on the relationship between the economic view and the social approach.

The first one assumes that economics is social; thus, there is no need for the particular science of sociology. In principle, no other action than economic exists. One should simply strengthen and develop the scope and method of economics. And if sociology nevertheless exists, its only purpose is to use economic methods and approaches in further sociological research. Trying to keep itself alive, sociology can also criticize economics, but it will remain just a "negative program" (Judin, 2010).

The second point of view treats economics and sociology as two independent spheres. The difference between them lies in different logics which are expressed in different notions, terms and concepts. Here, a social action is completely different from an economic one.

The third approach considers economics to be a case of sociology. Economic and social aspects constantly overlap. Even if there is an economic language, it includes notions and concepts not just from economic science, but also from philosophy, politology, law, psychology, sociology, and elements of natural language as well.

Taking these three points of view into account, a conclusion can be drawn that there are also three options to understand labour (Rogozhnikova, 2018).

The first assumes that labour is just an economic action, because there is nothing apart from economics.

The second supposes that labour can be considered both as an economic and as a social action. It is economic when the supply and the demand of labour are considered, and it is social when we mean the relationship between a worker and an employee or the social structure of the labour process.

The third treats economic labour as a case of social action, because even when the supply and the demand are considered, there are always social processes and structures that labour is involved in. One can abstract from this background while analyzing the economic meaning of labour in particular, but to understand the matter of labour, the social roots of economics must be taken into account. Everything that was said above allows one to specify the issue of labour as an economic and a non-economic action. 
H. Arendt (1998) treated labour as a non-economic action. In her understanding it is important for humans just to live as a biological species, while labour as a non-economic action is necessary in case of survival as non-biological creatures. Which seems to be more important? Our biological nature is basic to the non-biological one. That is, labour as a non-economic action correlates with labour as an economic action. Economic labour gives us the means to do non-economic labour, and the latter helps us not just to recover, but to feel like people, and not only like mechanisms.

Thus, we may list the following specifics of a non-economic action (Rogozhnikova, 2018):

- it is a type of work with any aim except for an economic one

- it has diverse motives, again except for economic ones

- it is connected to human dignity

- it is a personal activity

- it should be in balance with economic labour

The human model which could reflect such behaviour ought to be an interdisciplinary one. However, staying inside the economic field of research and understanding, for example, the constraints and possibilities of labour behaviour, the convergence of each sphere, economic and social, should be visible. The philosophy of economics can develop such a model for applying in cases of complex and interdisciplinary problems, such as labour.

The consequence of understanding work as an economic and non-economic activity results in two different management paradigms. Work as an economic activity entails the economic management paradigm. On the other hand, work as a non-economic activity entails a humanistic paradigm in management. In addition to a different understanding of work, both approaches and their paradigms perceive a worker differently.

\section{Man in the economic paradigm}

Contemporary management theory created by economists derives from neoclassical human theories (Ghoshal, 2005). According to its assumptions, people strive to increase the material utility of broadly understood benefits. However, it is common for them to prefer their own individual benefits, rather than social, collective ones.

Economic management assumes that each individual enters into relationships with other people primarily to meet his own needs (Pirson and von Kimakowitz, 2014). In this way, man seeks satisfaction from his efforts, often acting opportunistically for his own gain. A person perceived in this way, called homo economicus, is someone acting in accordance with the principles of economic rationality. J. S. Mill, a representative of classical economics, was the first to outline the psychological model (theoretical construction) of a homo economicus. He stated that political economy accepts in advance an arbitrary 
definition of man as a being invariably working to obtain the most necessary needs, facilities and luxuries, with the least workload and self-denial and in light of the current level of knowledge (Mill, 2000). In his opinion, economics should focus its research primarily on human activities resulting from economic motives and lead to material wellbeing and wealth. And although he assumed that in the activities of individuals, in addition to economic motives, there are also moral motives, the former play a dominant role.

The economic paradigm, the source of which is Enlightenment utilitarianism, perceives the human as an individual engaging only in short-term relationships with other people. Each commitment is based on the personal interests of the individual, and other people are treated as means necessary to achieve the goal. Therefore, such a person acts in a conformist way, and his actions are caused mainly by the lower needs in Maslow's hierarchy. Since his activities are not evaluated in terms of universal social utility, he is considered to be amoral.

The management paradigm based on the homo economicus concept guarantees rational economic efficiency of human activity. The proponents of this orientation assume that the main goal of the company is to maximize profit, and the primary and only responsibility that managers bear is to bring profit to shareholders who own the enterprise (Mazur, 2017).

The effects of widespread use of the economic paradigm in the global economy can be seen at three levels: systemic, organizational and individual (Pirson and von Kimakowitz, 2014). At the system level, irreversible destruction of the natural environment occurs because the modern global economy consumes a disproportionate amount of resources compared to the possibilities. At the organizational level, there is a decrease in social capital because interpersonal relationships seen in the perspective of profit maximization are instrumental in nature. In relation to a person, we can observe that the increase in the level of national income resulting from economic management is not tantamount to an increase in the level of employee well-being.

\section{Man in the humanistic paradigm}

In contrast to the economic paradigm, the humanistic approach assumes that human nature is not given once and for all and can be improved by systematic education (Pirson and von Kimakowitz, 2014). However, what distinguishes the economic approach from the humanist approach is the ethical element, which remains the leading category in the humanist paradigm. Its significance results from the fact that each person is assigned an inalienable right to respect for their own dignity, regardless of ethnicity, nationality, social status or gender. The humanistic perspective identifies man as a rational being that realizes its right to freedom in social interaction based on values. According to Aristotle's definition of man, he is a politikon zoon - a being by nature capable of participating in the social and political life of the state. 
The humanistic trend in management focuses on all phenomena concerning man and his place in the organization. In search of the roots of humanistic management, the 'avant la lettre' concept of management is sometimes referred to. It sets the good of the human being as its primary goal (Rąb, 2015). The ideas of utopian socialists C. Fourier and R. Owen represent examples of the 'avant la lettre' concept. Their beliefs are not considered only as narrowly understood projects of the organization, but are treated as a humanistic vision of the society of the future. Humanistic management, having utopian thinkers of the nineteenth century as its precursors, gained its present form during the twentieth century. Researchers take the perspective of the evolutionary development of humanistic management principles. Three stages in the process of forming the foundations of humanistic management can be distinguished. They were shaped respectively at the beginning of the twentieth century, in the mid-twentieth century and at the turn of the twenty-first century (Melé, 2009; 2013).

Key assumptions which the humanistic concept of the organization is based on include:

- the perception of the organization as a group of people who, as members of the community, recognize their own well-being and society's well-being as the main objective of the organization, and

- recognize management as a human practice, the aim of which is to bring about the best functioning of a given organization (Melé, 2003; 2013).

Humanistic management is accompanied by a cogitation of a deeply philosophical nature. According to this reflection, it can manifest itself in ontological, epistemological, axiological and praxeological dimensions (Arandia and Portales, 2015). In the ontological dimension, it manifests itself through self-awareness, rationality, socialization and language. In the epistemological one, it manifests itself through humanism and spirituality, but it can also be observed and analyzed in areas such as sociology of work, anthropology and phenomenology. In the axiological dimension, it manifests itself through respect for human dignity, equal treatment of all people, empathy, solidarity, freedom, trust and responsibility. In praxeology, humanistic management is demonstrated through the development of talents, dialogue with the internal and external stakeholders of the organization, and management compatible with the broadly conceived concept of sustainable development.

\section{Humanities management vs economic management}

The relation between management based on the economic and humanistic paradigms can be described as twofold. Two positions concerning both can be outlined: separation and integration. 


\section{Separation approach}

The "founding fathers" of management studies are thought to be M. Weber and F. Taylor. It is recognized that $\mathrm{M}$. Weber initiated the humanistic trend, which then began to develop particularly within universities, and $\mathrm{F}$. Tylor gave rise to the economic trend, represented primarily by economics universities and commercial schools (Kostera and Kociatkiewicz, 2013). Despite the fact that in recent decades these two trends have overlapped, repeatedly met intellectually and supported each other, some researchers claim that since their inception, they have retained their own distinctiveness because of the different subjects undertaken in their framework areas and different methodological preferences (Kostera and Kociatkiewicz, 2013). Table 1 depicts the differences between the approaches in relation to basic management issues, such as the accepted paradigms, the aim and object of research and the research methods applied in the two approaches.

Table 1

\section{Humanistic and economic trends in management studies}

\begin{tabular}{lll}
\hline \multicolumn{1}{c}{ Specification } & \multicolumn{1}{c}{ Humanistic trend } & \multicolumn{1}{c}{ Economic trend } \\
\hline Main precursors & $\begin{array}{l}\text { Adam Smith (moral } \\
\text { philosophy) } \\
\text { Max Weber } \\
\text { Elton Mayo }\end{array}$ & $\begin{array}{l}\text { Adam Smith (economics) } \\
\text { Frederick Taylor } \\
\text { Henri Fayol }\end{array}$ \\
\hline Paradigms & Qualitative case study & $\begin{array}{l}\text { Functionalist Radical- } \\
\text { structural }\end{array}$ \\
\hline Methodology & $\begin{array}{l}\text { Organizations (and } \\
\text { management) from the human } \\
\text { perspective }\end{array}$ & $\begin{array}{l}\text { Organizations (and } \\
\text { management) from an } \\
\text { efficiency perspective }\end{array}$ \\
\hline Purpect of study & $\begin{array}{l}\text { Increasing the well-being of } \\
\text { people in organizations. }\end{array}$ & $\begin{array}{l}\text { Increasing organization and } \\
\text { management efficiency. }\end{array}$ \\
& $\begin{array}{l}\text { Understanding organization } \\
\text { and management mechanisms } \\
\text { from a human perspective. }\end{array}$ & $\begin{array}{l}\text { Understanding organization } \\
\text { and management mechanisms } \\
\text { from the perspective of market } \\
\text { principles. }\end{array}$ \\
\hline
\end{tabular}

Source: based on Kostera, M. and Kociatkiewicz, J. (2013).

The research undertaken under both trends is often based on substantially different paradigmatic bases. In social studies, G. Burrell and G. Morgan (2003) distinguished four types of paradigms divided between their objective and subjective recognition (depending on the fundamental beliefs about the nature of science and the nature of society). Both humanities and economics rely on them.

The humanistic trend prefers two non-objectivistic paradigms (humanistic, evaluative), while the economic trend is based on objectivistic paradigms (functionalist, structuralist). 
This not only stems from research traditions which these teachings appeal to, but is also linked to the subject of research adopted. The humanistic trend is essentially interested in all manifestations and patterns from the point of view of a human and his place in the organization. Therefore, it seems natural to choose the paradigms that put man in the centre, emphasizing his ontological status as an actor endowed with causative power and responsibility (Kostera and Kociatkiewicz, 2013). On the other hand, the economic trend is understandably interested in the study of phenomena and abstract regularities, detached from the perspective of individual human experience and subjectivity. Therefore, the researchers' inclination to base their research on paradigms assuming both the existence and the significance of such objective creations should be understood (Kostera and Kociatkiewicz, 2013). The paradigmatic preferences are followed by the preference for using specific types of research methods. Those researchers who adopt assumptions derived from non-objective paradigms (humanists) use qualitative methods to study the development of phenomena over time (Kostera, 2008). Typical methods of this type are ethnography, grounded theory, critical analysis of culture, and ethnomethodology. In turn, the objectivist researchers, representing the economic trend, prefer the formulation of a general theory, describing the state of things. Quantitative methods, statistical methods, but also mathematical modelling is what allows them to do this. Both trends share a common area: case studies of different types, allowing one to define both the growth process and the state of the phenomenon. A case study may contain both qualitative and quantitative elements (Szydlo, 2015). In both trends, research using case studies is undertaken particularly keenly for the purpose of consulting. The difference is that the humanistic trend prefers the action research consulting type, designed to educate and improve the fortune of participants in the organization. The economic trend is related to pro-efficiency consulting. These different types of consulting result from the different research purposes under the two trends; the humanistic one is oriented toward helping a person improve his fate, and the economic trend is focused on improving the efficiency indicators of the organization. The cognitive objective is partially common for both trends - understanding and describing the organization and management - except that the accepted point of view is different for humanists and economists; it is either humanistic or related to efficiency. It is here that the fundamental difference between humanistic and economic management becomes clear. The first one seeks to answer the question of why manage, and the second one addresses how to do it.

\section{Integrative approach}

Humanistic management involves strategies and practices aimed at creating human wellbeing. It unconditionally respects human dignity by subjecting the activities of the organization to social assessment. By engaging in an open dialogue concerning values, managers should realize that the ultimate goal of business is to serve people, also in an economic sense. Humanistic management, by integrating both dimensions of business 
operations - economic and moral - helps companies perform a society-friendly role. Exclusive economic management does not allow this role to be fulfilled completely.

Humanistic management takes place in organizations that have managed to develop financially attractive business models and business practices that respect human dignity. Humanistically managed companies create products and provide services that are directed to meet true human needs and do so in a way that respects the expectations of all stakeholder groups. Numerous studies prove that social entrepreneurship largely implements the premises of humanistic management. A truly humanistic business is one that stops at achieving a satisfactory profit without absolutizing its maximization, and as a priority it assumes to make a human being a measure of all things (Von Kimakowitz et al., 2011). The main goal of companies implementing humanistic management is to eliminate human suffering and create conditions leading to a better life. Humanistic management, putting profit after people, also recognizes their role in achieving its goals. The integrated model of humanistic management indicates the need to relativize financial profit in relation to the humanistic goals of the organization. Profit, as H. Spitzeck argues, is a necessary but insufficient condition for humanistic management (Spitzeck, 2011). He considers the moral values and humanistic perception of management as necessary for the sustainable future of our planet and necessary in respecting human dignity in a business environment.

In 20th-century management theory, the mainstream was based on the perception of man in the category of homo economicus. In light of the adopted model of the human being in economic theory, business was perceived through the prism of economic profit and human relations were viewed as ordinary transactions. This approach meant that managers only included economic facts, ignoring the human and ethical dimensions of business operations (Mele, 2013). The humanistic synthesis, which is a different view on the ethicseconomics relationship in an economic activity, perceives ethics as the internal dimension of human action and, consequently, of all economic actions. W. Grassl and A. Habisch (2011) emphasize the interdependence of ethics and economic activities and their inseparable ontological relationship.

Therefore, the preference for the paradigms putting man at the centre, emphasizing his ontological status, and recognizing him as a being endowed with agency and responsibility seems to be natural.

According to practitioners, humanistic management was created as a complement to economic management, which is understood as hard, project-type management. It was also a supplement to the universally applicable (until recently) management culture based on summaries, analyses, tables, and a very orderly decision-making process. In this approach, economic management is a set of processes, rules, and principles of a person who manages a team performing specific tasks and accounts and overseeing the tasks ordered (Mazur, 2017).

The beginnings of humanistic management are associated with the emergence of new management methods: diversity management, talent management, age management, etc. 
This particular type of management became more important when managers started to rely less on lists and tables and began noticing the role of teams in organizations. In this regard, it was important to select the right people for a team. It was insufficient to respect the deadlines and procedures specific to project management; personality, partnership at work, and ability to work in a team began to gain significance.

In humanistic management, the selection of appropriate people with a set of similar values and interests and a common way of perceiving reality was considered key. In such management, the greatest difficulty is to engage employees because the line between humanistic management and an interregnum is thin.

In the case of young managers, it is primarily beneficial to embed economic management culture and, over time, to give it elements of humanistic management.

\section{DISCUSSION}

The pandemic is changing the methods of managing people. In a crisis situation, the health and safety of employees turn out to be the most important things. Among many types of crisis situations, pandemics have the capability of creating widespread change. Using the same habitual management styles and practices is often inadequate in such mass-scale disruption. One of the reasons for this change is that during the COVID-19 pandemic, man became the guarantor of the effective operation of enterprises. Therefore, the need to care for the well-being of employees resulted in an approach integrating the economic and humanistic paradigm in people management on a larger scale. The role of HR departments has also changed. Many of them considered it their task to listen to employees, be in touch with them and address their needs and concerns as best as possible. In this perspective the humanistic paradigm is getting closer to the commonly used economic paradigm of human resource management.

The support and care for the well-being of employees in the pandemic era manifested itself in the fact that, whenever possible, employees were encouraged to work from home. Companies also ensure that people have the right equipment and tools to work online. According to the theory of organizational support, employees who perceive their workplace as supportive are more sympathetic to their organizations and willing to invest more effort in the tasks performed. Such a strategy of approaching employees is therefore not only humanistic, it is also profitable in the long run.

\section{CONCLUSIONS}

1. Work understood as economic action and non-economic action is the basis of two different management paradigms, respectively economic and humanistic. 
Combined in an integrated method of management, they create a new human model in management referring to man as homo economicus and politikon zoon.

2. Labour as an economic and non-economic action shows how different activities in our life correlate to each other, and that there is a need to find a balance between them in everyday life. In the case of further dominance of work understood as economic activity, the economization of social life will be more and more common, which may end up with the total mechanization of our lives. There is no other possibility to understand complex phenomena in any field of research concerning the human being, except for studying human actions. Understanding the labour process, especially with regard to humanistic management, could be very fruitful for the economic view on the human being.

3. Adopting a humanistic perspective in the management process may be a significant contribution to a holistic study of the organization and its activities, which were previously mostly the domain of economists. Both descriptions of an organization - economic and humanistic - are complementary and create the characteristics of the same phenomena in light of each of these approaches. Considering the positions presented, the statement that management needs humanists and humanists need management seems to be more than relevant. 


\section{REFERENCES}

1. Arandia, O., Portales, L. (2015), "Fundamentos de la gestión humanista: una perspectiva filosófica [Underpinnings of humanistic management: a philosophical approach]", $A D$ minister, No. 26, enero-junio, pp. 124-139.

2. Arendt, H. (1998), The Human Condition, 2nd ed. Chicago: The University of Chicago Press.

3. Becker, G. (2008), "Human Capital", in Henderson, D. R. (Ed.), The Concise Encyclopedia of Economics, Liberty Fund, USA, pp. 248-250, available at: http://www.econlib.org/library/Enc/HumanCapital.html

4. Burrell, G., Morgan, G. (1979), Sociological Paradigms and Organisational Analysis: Elements of the Sociology of Corporate Life, Heinemann, London.

5. Elger, T. (2006), “Labor”, in Turner, B. S. (Ed.), The Cambridge Dictionary of Sociology, UK, pp. 315-318.

6. Ghoshal, S. (2005), "Bad Management Theories Are Destroying Good Management Practices", Academy of Management Learning and Education, Vol. 4, No. 1, pp. 75-91.

7. Grassl, W., Habisch, A. (2011), "Ethics and Economics: Towards a New Humanistic Synthesis for Business", Journal of Business Ethics, Vol. 99, No. 1, pp. 37-49.

8. Judin, G. B. (2010), “'Economic' and 'Social': Autonomy of the Spheres and Disciplinary Boundaries ['Jekonomicheskoe' and 'social'noe': avtonomija spheres and disciplinary border]”, Voprosy Ekonomiki, Vol. 8, pp. 54-71.

9. Kostera, M. (Ed.) (2008), Organizational Olympians: Heroes and Heroines of Organizational Myths (Introduction), Palgrave, Basingstoke.

10. Kostera, M., Kociatkiewicz, J. (2013), "Humanistic management. Zarys programu", Problemy Zarzadzania, Vol. 11, No. 44, pp. 9-19.

11. Mazur, B. (2017), "Diversity in the perspective of economic and humanistic management", Przedsiębiorczość i Zarządzanie, Vol. 18, No. 11, Part 2, pp. 9-19.

12. Melé, D. (2003), "The Challenge of Humanistic Management", Journal of Business Ethics, Vol. 44, No. 1, pp. 77-88.

13. Melé, D. (2009), "Editorial introduction: Towards a more humanistic management", Journal of Business Ethics, Vol. 88, No. 3, pp. 413-416.

14. Melé, D. (2013), “Antecedents and current situation of humanistic management”, African Journal of Business Ethics, Vol. 7, No. 2, Conference Edition, pp. 52-61. 
15. Mill, J. S. (2000), The Collected Works of John Stuart Mill, University of Toronto Press, available at: https://oll.libertyfund.org/titles/mill-the-collected-works-of-john-stuart-millvolume-xxi-essays-on-equality-law-and-education

16. Pirson, M., Goodpaster, K. and Dierksmeier, C. (2016), "Human Dignity and Business", Business Ethics Quarterly, Vol. 26, No. 4, pp. 465-468.

17. Rąb, K. (2015), "Innovations in human resource management - in the humanistic site", Zeszyty Naukowe Politechniki Śląskiej, Vol. 85, No. 1943, pp. 447-456.

18. Rogozhnikova, V. (2018), "Labor as a non-economic action", Proceedings of the 5th International Multidisciplinary Scientific Conferences on Social Sciences and Arts SGEM 2018, Vol. 18, Book 1.4, pp. 479-486.

19. Schultz, T. W. (1972), "Human Capital: Policy Issues and Research Opportunities", in Economic Research: Retrospect and Prospect, Vol. 6. Human Resources, National Bureau of Economic Research, Inc, pp. 1-84.

20. Sison, A. J. G. (1992), “The virtualities of the concept of work in St. Thomas Aquinas. A commentary on 'De opere manuali' and 'Contra impugnantes Dei religionem et cultum'”, paper presented at IX Congrès International de la Société International pour l'Étude de la Philosophie Médiévale, Ottawa (Canada).

21. Sison, A. J. G., Ferrero, I. and Guitian, G. (2016), "Human Dignity and the Dignity of Work: Insights from Catholic Social Teaching”, Business Ethics Quarterly, Vol. 26, No. 4, pp. 503-528.

22. Spitzeck, H. (2011), “An Integrated Model of Humanistic Management”, Journal of Business Ethics, Vol. 99, No. 1, pp. 51-62.

23. Szydlo, J. (2015), "Case study in the study of organizational culture, Studies in intercultural management”, Przedsiębiorczość i Zarządzanie, Vol. 13, No. 3(1), pp. 249262.

24. Ulrich, P. (2008), Integrative Economic Ethics: Foundations of a Civilized Market Economy, Cambridge University Press, Cambridge.

25. Von Kimakowitz, E., Pirson, M., Spitzeck, H., Dierksmeier, C. and Amann, W. (Eds.) (2011), Humanistic Management in Practice, Palgrave-MacMillan, New York. 
Received: 2 April 2020

Accepted for publishing: 6 January 2021

DOI: $10.32025 / J B M 19002$

\section{In search of high-performance workplace factors among SMEs}

JANIS GERCANS

\section{ABSTRACT}

Purpose. Small and medium-sized enterprises (SMEs) are essential contributors to employment creation and global economic growth. For long-term survival in the market, SMEs need the capabilities to organise their resources in a way that leads to high performance and competitive advantage. Based on the conceptual framework of entrepreneurial orientation and the resourcebased view of the firm, performance-influencing organisational factors among SMEs providing manufacturing services are analysed.

Methodology. In this study, the financial performance of 47 SMEs was analysed, and a survey of 499 employees was conducted. Financial performance was evaluated by ROA and ROS, and productivity was measured by turnover and net profit per employee to identify high-performance SMEs. Competitive aggressiveness was measured by changes in the market share to verify whether the high-performance group of SMEs corresponds to the entrepreneurial orientation construct. A questionnaire with a six-point Likert scale and the Mann-Whitney U test were used to test the hypotheses.

Findings. The managerial capabilities to create strong workplace performance exist where: (a) management has a respectful attitude toward employees, (b) management supports the development of employees' professional skills, (c) employees are provided with everything they need to achieve high job results, (d) employees want to work for the company in the long term, (e) remuneration to employees is fully in line with their level of professional skills, (f) co-workers perform their work effectively, (g) employees work shorter job shifts. These elements constitute the knowledge-based resources of high-performance SMEs, giving them, at a minimum, a temporary competitive advantage.

Value. The findings of this article contribute to the literature on entrepreneurial orientation, supplementing the construct of organisational factors with the characteristics of managerial capabilities leading to high performance and competitive advantage.

Keywords: entrepreneurial orientation, managerial capability, performance, forestry SMEs

Paper category: research paper 


\section{INTRODUCTION}

On the global scale, the process of delivering goods and services to consumers has become highly specialised. Businesses focus on their strengths in home markets and outsource their other needs (World Bank, 2020), thereby creating global value chains with multiple companies involved in the manufacturing process. A typical model of a global value chain consists of large organisations that contract smaller organisations for the services needed to deliver their products to the market. Therefore, small and medium-sized enterprises (SMEs) become an important link in the creation of wealth across the globe. According to Ayyagari et al. (2014), the SME sector's contribution is comparable to that of large firms. SMEs have the largest share of employment creation and the highest sales and employment growth. Large companies, however, have higher productivity growth. Therefore, it is essential to focus research on the capabilities of SMEs to survive and thrive as a part of a value chain or as individual companies.

To be successful in the market, a company needs to create a competitive advantage. The creation of sustained competitive advantage depends on the unique resources and capabilities that a company uses to compete in its market. Managers must search inside their company for valuable, rare and costly-to-imitate resources, and then use these resources in their organisation (Barney, 1995). Therefore, managerial knowledge and capabilities play an important role in the success of a company. In particular, managerial capabilities can be internal factors that limit the growth of a company (Penrose, 1959) because the valuable, rare and socially complex resources and capabilities of the company must be organised in a way that exploits its full competitive potential (Barney, 1995). From the perspective of the resource-based view of the firm (RBV), resources can be divided into those that are knowledge-based and those that are property-based (Penrose, 1959; Miller and Shamsie, 1996). Managerial capabilities comprise a knowledge-based resource of a company and, compared to property-based resources, are better designed to respond and adapt to the challenges facing the company. This is because knowledge-based resources provide the company with the skills needed to adapt their products to market needs and to deal with competitive challenges (Miller and Shamsie, 1996).

Moreover, the complexity and tacitness of technological knowledge are useful for protecting the significant product improvements of a company from imitation (McEvily and Chakravarthy, 2002). However, companies with similar capabilities might have different economic returns depending on the composition of their competitors (Chatain, 2010). This might also be explained by the fact that the performance of a company depends on the performance of its employees, regardless of the size of the company and its other characteristics (Aguinis, 2009). In this light, the proposition by Hansen et al. (2004) is very topical. Hansen et al. propose to shift the focus of RBV research from the relationship between resources, capabilities and the financial performance of the company to the relationship between administrative decisions and company-level financial performance. For this purpose, the entrepreneurial orientation (EO) construct is a suitable 
approach. It embraces an essential aspect of the way a company is organised, and it suggests that knowledge-based resources are positively related to a company's performance and that EO enhances this relationship (Wiklund and Shepherd, 2003).

Considering that SMEs individually, or as a part of large organisations' value chains, contribute remarkably to global economic activity - and that the managerial capabilities of these companies play an essential role in the management of resources, the creation of competitive advantage and the growth of the companies - the following research question is proposed: What differentiating characteristics of managerial capabilities result in high performance and competitive advantage of SMEs? The objective of this article is to determine the differentiating characteristics of managerial capabilities in high-performance SMEs. The study is based on the conceptual framework of EO and the resource-based view of the firm.

The next section of the study is the literature review, a depiction of the theoretical background and the development of the hypotheses. The third section contains a representation of the research methods. In the fourth section, the study results are reported. Then, in the fifth section, the findings are discussed, and recommendations for further research are proposed. In the sixth section, the article concludes with an outline of the limitations of the study.

\section{LITERATURE REVIEW}

\section{The resource-based view of the firm}

RBV focuses on the resources and capabilities controlled by a company that underlie persistent performance differentials among competitors (Peteraf and Barney, 2003). A business company is both an administrative organisation and collection of productive resources (Penrose, 1959). The value of administrative, or knowledge-based (Miller and Shamsie, 1996), resources is reflected in the quality of administrative decisions that influence the performance of the company (Hansen et al., 2004). To create more value than its competitors, a company must produce greater net benefits, through superior differentiation and/or lower costs (Peteraf and Barney, 2003). Although companies may possess similar or homogeneous property-based resources, due to different knowledge of how to exploit them, companies are capable of rendering different productive services (Penrose, 1959). This means that, due to resource heterogeneity, some companies have resources that generate more value than others (Peteraf, 1993). Therefore, companies with superior, more value-generating resources will have a competitive advantage (Peteraf and Barney, 2003). The more valuable and rarer a company's resource-capability combinations are, the higher the probability will be that it will have a competitive advantage (Newbert, 2008). Meanwhile, a company has a competitive advantage if it is capable of generating more economic value than a marginal competitor in its product. Also, the economic value 
generated by a company is the difference between the perceived benefits of the product buyers and the economic cost to the company. Several or even many companies in a given industry may have a competitive advantage (Peteraf and Barney, 2003). The potential of a company's competitive advantage depends on the value, rareness, and imitability of its resources and capabilities, as well as on its organisational readiness to exploit these resources and capabilities, known as the VRIO framework (Barney, 1995). Resources and capabilities, such as research and development intensity and advertising intensity, positively influence financial performance, lead to resource heterogeneity and assist a company in achieving competitive advantage (Nair and Bhattacharyya, 2019). Previous studies on EO show that when applied to the VRIO framework, EO represents how a company is ready to discover and exploit opportunities (Wiklund and Shepherd, 2003). Therefore, in this study, RBV and EO are taken as theoretical concepts to explain how characteristics of managerial capabilities result in SMEs having a high level of performance and a competitive advantage.

\section{Entrepreneurial orientation}

EO is positively associated with the financial performance of a company (Poudel et al., 2019). EO can assist in the explanation of managerial processes that provide some companies with the capability to use their resources and to respond to challenges earlier than their competitors (Wiklund and Shepherd, 2003). EO is characterised by entrepreneurial themes, which include the dimensions of autonomy, innovativeness, risktaking, proactiveness and competitive aggressiveness (Lumpkin and Dess, 1996; Wales et $a l ., 2020)$. It moderates the relationship between a collection of knowledge-based resources and company performance (Wiklund and Shepherd, 2003). Managerial competence is a vital function of the quality of the entrepreneurial services available to the company (Penrose, 1959). Factors such as managerial style, need for achievement and other social or motivational factors might help to explain a company's performance (Lumpkin and Dess, 1996). EO, as an organisational property, shows up when an organisation's top management style, organisational configuration, and new entry initiatives demonstrate an entrepreneurial theme (Wales et al., 2020). Companies managed by executives with high individualism will have a higher performance than those whose executives have low individualism (Yucel, 2011). Executives with superior reasoning and problem-solving capabilities are likely to have more potential to design more effective business models and to make more intelligent investment decisions (Helfat and Peteraf, 2015). Moreover, executives whose personalities reflect higher core self-evaluations have a stronger positive influence on their company's EO (Simsek et al., 2010). Furthermore, EO facilitates SMEs in achieving environmental sustainability and improving performance (Amankwah-Amoah et al., 2019), while green purchasing capabilities have a positive effect on the growth of a company, and this relationship is positively moderated by the environmental orientation of the chief executive officer (CEO) (Andersén et al., 2020). CEO founder status is positively related to EO (Deb and Wiklund, 2017). This indicates 
the importance of managerial capabilities in leading a company to success in the market. Capabilities, in general, encompass the capacity to perform physical and mental activities (Helfat and Peteraf, 2015). Meanwhile, managerial capabilities embrace the managerial knowledge of individuals who work in the company. The individual's managerial knowledge consists of such domains as managerial, functional, technical, company and environmental knowledge (van den Bosch and van Wijk, 2001). Therefore, knowing how to create a high-performance workplace is a prerequisite to building a successful and competitive company, and managers play the leading role in this process.

\section{Workplace}

High-performance work practices in the development of individual workers' key competencies are essential in the creation of a high-performance organisation (Leoni, 2012). A study by Doeringer et al. (1998) shows that Japanese hybrid workplace systems emphasise social and organisational learning, employee participation in problem-solving and employee commitment as the principal means of motivating labour efficiency. Employees are rewarded with career advancement and high wages, and they respond with high labour productivity. Additionally, Smith (2003) points out that training structures and policies need to be supportive of learning in the workplace, and training personnel need to be skilled.

Furthermore, improvements in workplace organisation, including re-engineering, teams, incentive pay and employee participation, are a significant component of productivity growth. Productivity is higher in companies with more highly educated employees (Black and Lynch, 2001; 2004), flexible job assignments and employment security (Ichniowski et al., 1997). However, the effect of these practices on employees' welfare is diverse (Black and Lynch, 2004). Therefore, reward management is important in a company, which includes necessary strategies, policies and processes to ensure that the value of employees and the contribution they make to achieving objectives is recognised and rewarded (Armstrong, 2012). Many studies show that when monitoring costs are low, piece-rate payment is appropriate (Lazear, 1986) and pay-for-performance increases productivity (Shearer, 2004; Gielen et al., 2010) and attracts more skilled employees (Lazear, 2000; Gielen et al., 2010). Nonetheless, individuals value pay differentially, and those who attach a higher perceived value to pay are those who perform at higher levels in an incentive environment (Fox et al., 1993). However, reward management is not just about pay and employee benefits. It is also about non-financial rewards such as recognition, training and development opportunities and increased job responsibility (Armstrong, 2012).

Moreover, productivity increases when working alongside more capable friends (Bandiera et al., 2010). However, managers are important actors in the creation of a highperformance company. Knight (2000) stresses the importance of managers in adapting to changes in their environment at a tactical level and an operating level to employ the tactics 
needed to maintain or enhance the company's performance. Process management practices play an essential role in the adoption of environmental practice (Jakhar, 2016). Eisenhardt (2013) points out that successful top management teams are diverse, have a history of working together, can be conflictual but are quick to make strategic decisions, rely on 'simple rules' and are capable of designing an organisational structure. However, Buckingham and Coffman (1999) argue in their study that great managers do not believe that, with enough training, an employee can achieve anything; they do not try to help employees overcome their weaknesses but focus instead on the strengths of each individual. The authors also argue that no matter how generous its pay or how significant its expertise, a company that lacks great front-line managers will fail. Thus, the importance of managerial capabilities in creating a high-performance workplace is beyond question, and, according to Buckingham and Coffman (1999), the strength of a workplace can be measured by twelve questions, which cover the main elements needed to attract, focus and keep the most talented employees. However, Buckingham and Coffman's study (1999) embraced small and large companies from various industries. Therefore, in this study, it is argued that the differentiating characteristics of a high-performance workplace in the context of SMEs might differ from those found in previous studies. Thus, based on Buckingham and Coffman's (1999) characteristics of the high-performance workplace, and given that the performance of a company depends on the performance of its people (Aguinis, 2009) and that due to resource heterogeneity some companies have resources that generate more value than others (Peteraf, 1993), the following hypotheses are put forward:

$\mathrm{H}_{1}$ : the management of high-performing SMEs has the capabilities to create a workplace that differs significantly by having the following characteristics of a productive workplace:

a) employees' remuneration is based on pay-for-performance

b) employees' salary is fully in line with their level of professional skills

c) employees always receive recognition from company management for a wellperformed job

d) employees are doing the job they can do best

e) employees are supplied with everything they need to achieve high job results

f) employees know what is expected from them

g) employees regularly receive a performance assessment from the management of the company

h) employees work shorter job shifts

i) the company management has a respectful attitude toward employees

j) the company management supports the development of employees' professional skills 
$\mathrm{H}_{2}$ : the management of high-performing SMEs has the capabilities to create a workplace that differs significantly by having the following characteristics of an engaging workplace:

a) co-workers perform their work effectively

b) employees always share information that can help to improve the skills of coworkers

c) employees always, when seeing an opportunity, put forward work improvement proposals to the management of the company

d) employees know that their work is important

e) employees want to work for their current company in the long term

f) relations among co-workers in the company are professional and friendly

In summary, based on the conceptual framework of EO (Lumpkin and Dess, 1996), the hypotheses derived from the literature review are elaborated in the following model.

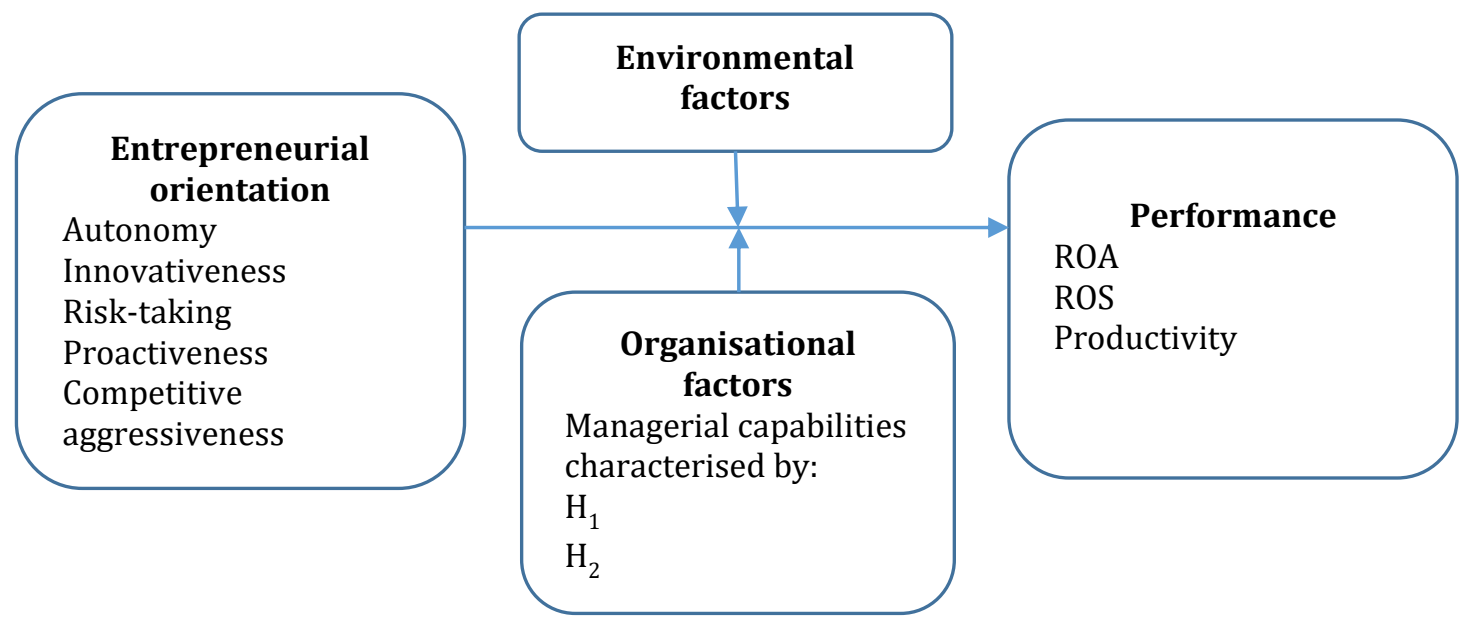

Figure 1 Managerial capabilities within the conceptual framework of EO

\section{METHODOLOGY}

In this study, the financial performance of 47 SMEs is analysed, while a survey of 499 employees was conducted between May and August 2019. All companies operate in the forest industry of Latvia. The employees surveyed were reached during training seminars organised by JSC Latvia's State Forests. Paper-form questionnaires were used. Survey data was analysed by SPSS (Statistical Package for the Social Sciences) software. To test the hypotheses, a questionnaire with a six-point Likert scale from "strongly disagree" to "strongly agree" was used. Before the survey, the questionnaire was pilot-tested to ensure 
the clarity of the questions. It is suggested that studies should include multiple performance measures, including traditional accounting measures and other elements of broader stakeholder satisfaction (Lumpkin and Dess, 1996). However, Pankaj and Rivkin (2006) point out that a company that earns superior, long-term financial returns within its industry has a competitive advantage. Therefore, in this study, financial indicators of eight years are taken from the Lursoft database to distinguish between high-performing SMEs and their competitors. Financial performance was evaluated using ROA (return on assets), ROS (return on sales) and productivity measured as turnover and net profit per employee. To identify high-performance SMEs, the following steps have been taken: (1) For each financial performance criterion, SMEs were ranked in descending order according to mean values over eight years, and the rank value was attached, where 1 means the highest performance and 47 the lowest. (2) The mean value of ranks for each SME was calculated. (3) SMEs were ranked in ascending order by the mean value of ranks, where the lowest value means the highest average performance in a given criterion. (4) In the final step, the list of SMEs was divided into quartiles, and the first quartile of SMEs with the lowest mean values of ranks was set as the first, high-performing group of SMEs, and the second to fourth quartiles were set as the second group of SMEs. Competitive aggressiveness (Lumpkin and Dess, 1996) was measured by the changes in the market share for the eightyear period to verify whether the first group of SMEs corresponds to the EO construct. All selected companies provide roundwood manufacturing services for JSC Latvia's State Forests, where contracts are awarded in open tenders, and the price for the service is a dominating factor. Therefore, the changes in the market share represent the competitiveness of the company. The Mann-Whitney $U$ test was used to test the competitive advantage of the first group of SMEs. Cronbach's $\alpha$ was applied as a test of the questionnaire data reliability. The Mann-Whitney U test was used to test the hypotheses, as the data do not meet the requirements of a normal distribution.

The methodology for the selection of high-performance SMEs and the test of the hypotheses of this study are illustrated in the following model: 


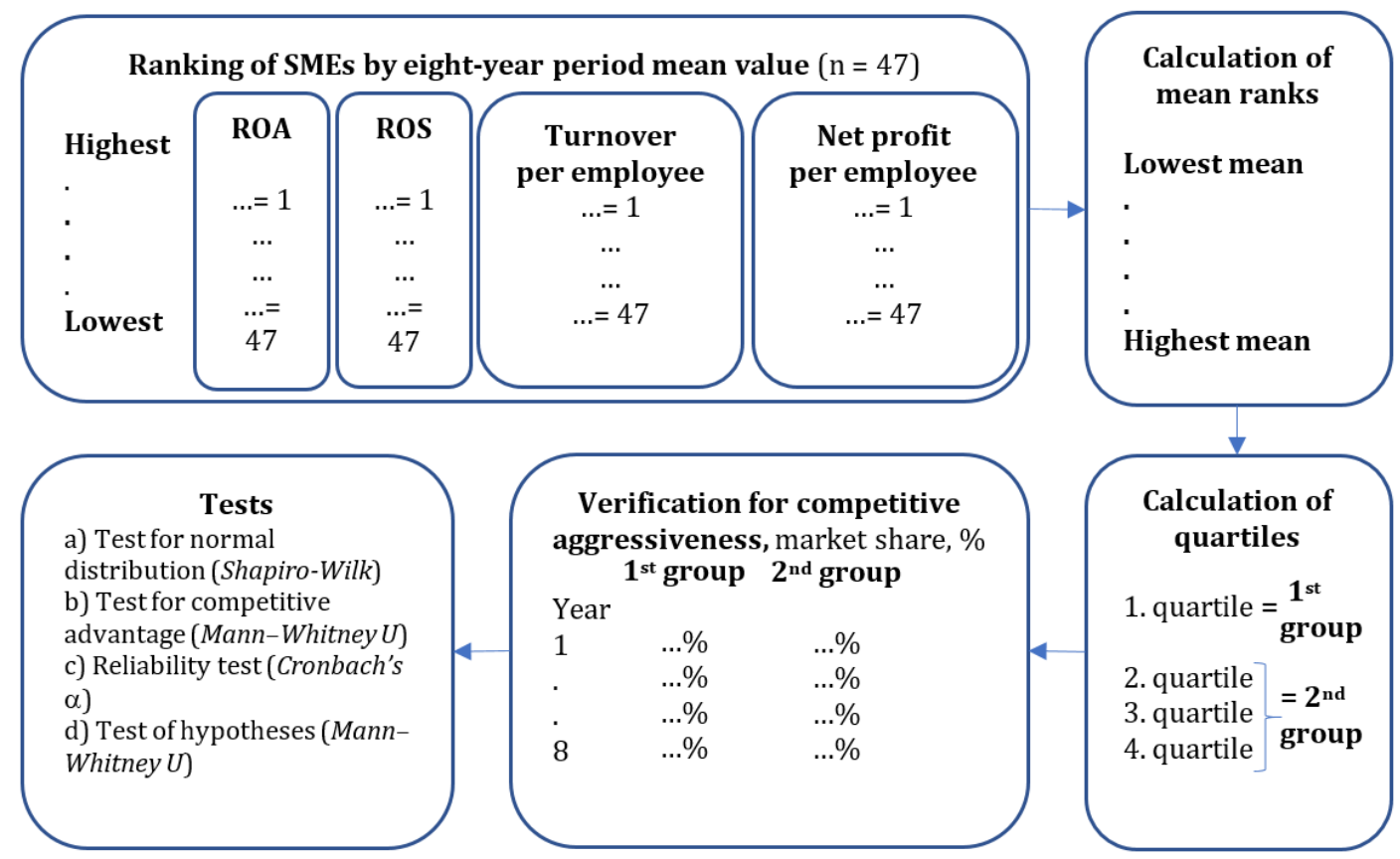

Figure 2. Methodology for the selection of high-performance SMEs and the test of hypotheses

\section{RESULTS}

Financial returns of the eight-year period were analysed to identify whether the first group of SMEs had a competitive advantage. The results show that the first group had significantly higher ROA, ROS, turnover per employee and net profit per employee in this period. The results are presented in Table 1.

Table 1

Mean values of eight-year period (2011-2018) financial returns of SMEs $(n=47)$ and number of employees

\begin{tabular}{lccccc}
\hline Criterion & ROA, \% & ROS, \% & $\begin{array}{c}\text { Turnover per } \\
\text { employee, } \\
\text { K€ }\end{array}$ & $\begin{array}{c}\text { Net profit per } \\
\text { employee, K€ }\end{array}$ & $\begin{array}{c}\text { Number of } \\
\text { employees }\end{array}$ \\
\hline $\begin{array}{l}\text { group } \\
(\mathbf{n}=\mathbf{1 2})\end{array}$ & $(S D 14.8)$ & $(S D 5.9)$ & $(S D 66.9)$ & $(S D 13.4)$ & $(S D 35.5)$ \\
\hline $\begin{array}{l}\text { group } \\
(\mathbf{n}=\mathbf{3 5})\end{array}$ & 4 & 4 & 72 & 2 & 43 \\
\hline p-value & $<D 57.5)$ & $(S D 8.3)$ & $(S D 96.1)$ & $(S D 4.5)$ & $(S D 43.8)$ \\
\hline
\end{tabular}

Sig. at a level of $p \leq 0.05$ 
Thus, the selected group of high-performing SMEs has a competitive advantage over its competitors in the second group. However, the number of employees is not significantly different, and the companies can be classified as SMEs based on the definition of the European Commission (Eurostat, 2020).

The changes in the market are analysed to verify whether the first group of SMEs possesses competitive aggressiveness. The results are presented in Figure 3.

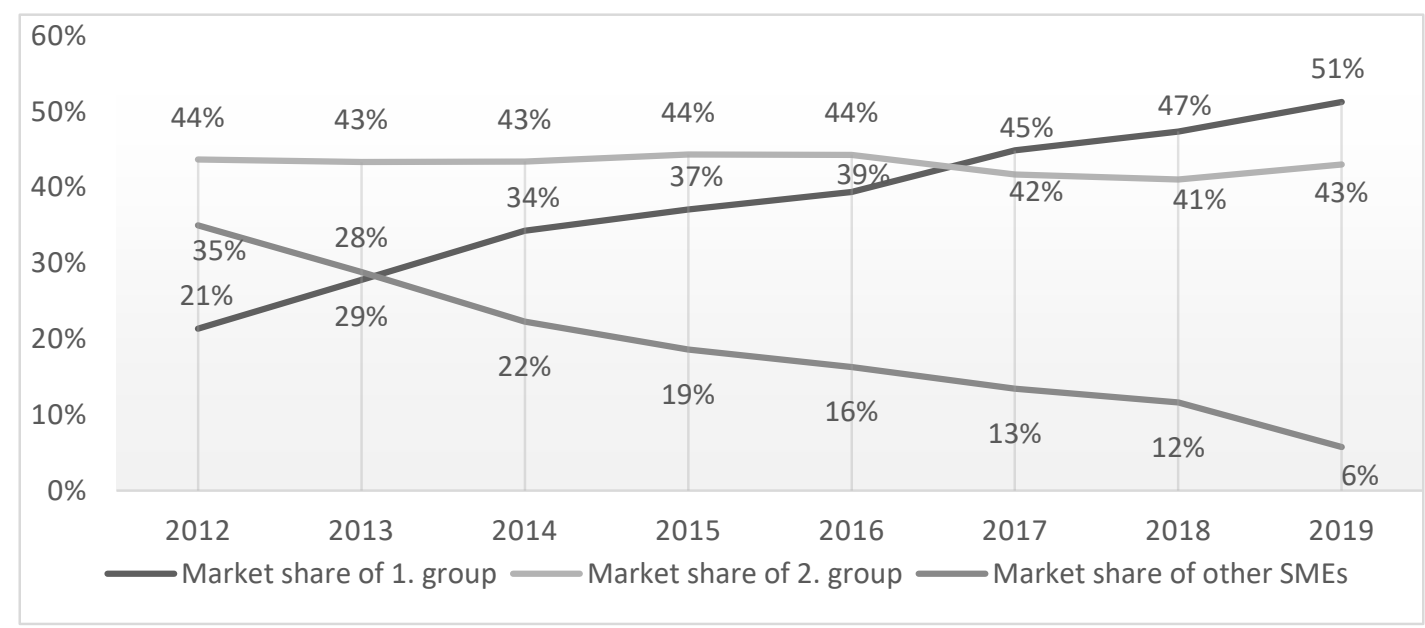

Figure 3 Changes in the market share of the first and second groups of SMEs

SMEs in the first group were capable of increasing their market share from $21 \%$ in 2012 to $51 \%$ in 2019 , a $30 \%$ increase in eight years. However, the second group of SMEs lost one percent of its market share in eight years. It is thereby confirmed that the first group of SMEs possesses competitive advantage and EO as measured by competitive aggressiveness.

Before the test of the hypotheses, internal consistency was measured using Cronbach's $\alpha$ (Cronbach, 1951). For $\mathrm{H}_{1} \alpha=.839$, and for $\mathrm{H}_{2} \alpha=.716$, which represents good and acceptable internal consistency (Taber, 2018). For respondents from the first group of SMEs, $n=236$; for the second group of SMEs, $n=263$. The results of the $\mathrm{H}_{1}$ hypothesis test are shown in Table 2. 
Table 2

The results of the $\mathrm{H}_{1}$ hypothesis test

\begin{tabular}{|c|c|c|c|c|c|}
\hline No. & Item & $\begin{array}{l}\text { Group } \\
\text { of SMEs }\end{array}$ & $\begin{array}{c}\text { Mean } \\
\text { rank }\end{array}$ & $\boldsymbol{U}$ & $p$-value \\
\hline \multirow{2}{*}{$\mathrm{H}_{1 \mathrm{e}}$} & \multirow{2}{*}{$\begin{array}{l}\text { Employees are supplied with everything } \\
\text { they need to achieve high job results }\end{array}$} & 1 & 272.4 & \multirow{2}{*}{25737.0} & \multirow{2}{*}{$<.001$} \\
\hline & & 2 & 229.9 & & \\
\hline \multirow{2}{*}{$\mathrm{H}_{1 \mathrm{i}}$} & \multirow{2}{*}{$\begin{array}{l}\text { The company management has a respectful } \\
\text { attitude toward employees }\end{array}$} & 1 & 279.1 & \multirow{2}{*}{23937.5} & \multirow{2}{*}{$<.001$} \\
\hline & & 2 & 223.0 & & \\
\hline \multirow{2}{*}{$\mathrm{H}_{1 \mathrm{~b}}$} & \multirow{2}{*}{$\begin{array}{l}\text { Employees' salaries are fully in line with } \\
\text { their level of professional skills }\end{array}$} & 1 & 261.2 & \multirow{2}{*}{25383.0} & \multirow{2}{*}{.006} \\
\hline & & 2 & 227.8 & & \\
\hline \multirow[b]{2}{*}{$\mathrm{H}_{1 \mathrm{j}}$} & \multirow{2}{*}{$\begin{array}{l}\text { The company management supports the } \\
\text { development of employees' professional } \\
\text { skills }\end{array}$} & 1 & 264.7 & \multirow[b]{2}{*}{26633.0} & \multirow[b]{2}{*}{.008} \\
\hline & & 2 & 233.2 & & \\
\hline \multirow{2}{*}{$\begin{array}{l}\mathrm{H}_{1 \mathrm{j}} \\
\text { control }\end{array}$} & \multirow{2}{*}{$\begin{array}{l}\text { Employees always have a desire to improve } \\
\text { their professional skills }\end{array}$} & 1 & 248.8 & \multirow{2}{*}{30343.0} & \multirow{2}{*}{.898} \\
\hline & & 2 & 247.3 & & \\
\hline \multirow{2}{*}{$\mathrm{H}_{1 \mathrm{~h}}$} & \multirow{2}{*}{ Duration of the job shift } & 1 & 230.9 & \multirow{2}{*}{26546.0} & \multirow{2}{*}{.015} \\
\hline & & 2 & 261.4 & & \\
\hline \multirow{2}{*}{$\mathrm{H}_{1 \mathrm{a}}$} & \multirow{2}{*}{$\begin{array}{l}\text { The salary of employees depends on labour } \\
\text { productivity }\end{array}$} & 1 & 256.9 & \multirow{2}{*}{29408.5} & \multirow{2}{*}{.261} \\
\hline & & 2 & 243.8 & & \\
\hline \multirow{2}{*}{$\mathrm{H}_{1 \mathrm{a}}$} & \multirow{2}{*}{ The salary of employees depends on quality } & 1 & 256.6 & \multirow{2}{*}{29228.0} & \multirow{2}{*}{.265} \\
\hline & & 2 & 243.1 & & \\
\hline \multirow[b]{2}{*}{$\mathrm{H}_{1 \mathrm{c}}$} & Employees always receive recognition from & 1 & 254.0 & & \\
\hline & $\begin{array}{l}\text { company management for a well-performed } \\
\text { job }\end{array}$ & 2 & 241.7 & .5 & 0 \\
\hline & Employees know what is expected from & 1 & 253.0 & 45 & $518+2$ \\
\hline${ }_{11 f}$ & them & 2 & 245.5 & 29034.5 & .518 \\
\hline $\mathrm{H}_{1 \mathrm{f}}$ & The company management always explains & 1 & 258.6 & & \\
\hline control & $\begin{array}{l}\text { the requirements for work and their } \\
\text { importance }\end{array}$ & 2 & 237.7 & 5 & $T$ \\
\hline $\mathrm{H}_{1 \mathrm{~d}}$ & Employees are doing the job they can do & 1 & 246.9 & 30285.5 & .744 \\
\hline & best & 2 & 250.9 & 50205.5 & \\
\hline & Employees regularly receive a performance & 1 & 248.1 & & \\
\hline $\mathbf{H}_{1 \mathrm{~g}}$ & $\begin{array}{l}\text { assessment from the management of the } \\
\text { company }\end{array}$ & 2 & 249.8 & 30563.5 & .891 \\
\hline
\end{tabular}

Sig. at a level of $p \leq 0.05$

The management of high-performing SMEs has capabilities to create a workplace that differs significantly by having the following characteristics of a productive workplace: (1) employees are supplied with everything they need to achieve high job results, (2) the company management has a respectful attitude toward employees, (3) employees' salaries are fully in line with their level of professional skills, (4) the company management supports the development of employees' professional skills, (5) employees work shorter job shifts, $10 \mathrm{~h}$ (SD 4.6) and $11 \mathrm{~h}$ (SD 7.1) respectively. Therefore, H1e, H1i, H1b, H1j and $\mathrm{H} 1 \mathrm{~h}$ of the $\mathrm{H} 1$ hypothesis are accepted. Meanwhile, there is no significant difference in the following characteristics of the productive workplace: (1) employees' remuneration is based on pay-for-performance (the salary depends on productivity and quality), (2) 
employees always receive recognition from company management for a well-performed job, (3) employees know what is expected from them, (4) employees are doing the job they can do best, (5) employees regularly receive a performance assessment from the management of the company. Therefore, H1a, H1c, H1f, H1d and H1g of the H1 hypothesis are rejected.

The H1j part of the hypothesis was controlled by employees' desire to improve their professional skills. The results indicate that there is no significant difference between the employees of both groups of SMEs in terms of the desire to improve their professional skills (p-value .898). However, only the management of the first group of SMEs shows support for the development of employees' professional skills (p-value .008). Additionally, the H1f part of the hypothesis was controlled for whether managers explain the requirements for work and its importance to their employees. The results show that there is a trend (p-value .074) for the management of the first group of SMEs to give more attention to the explanation of the requirements for work and its importance. The results of the $\mathrm{H} 2$ hypothesis test are shown in Table 3.

Table 3

The results of the $\mathrm{H}_{2}$ hypothesis test

\begin{tabular}{|c|c|c|c|c|c|}
\hline No. & Item & $\begin{array}{l}\text { Group } \\
\text { of SMEs }\end{array}$ & $\begin{array}{l}\text { Mean } \\
\text { rank }\end{array}$ & $\boldsymbol{U}$ & $p$-value \\
\hline \multirow{2}{*}{$\mathrm{H}_{2 \mathrm{e}}$} & \multirow{2}{*}{$\begin{array}{l}\text { Employees want to work for the current } \\
\text { company in the long term }\end{array}$} & 1 & 276.2 & \multirow{2}{*}{24852.0} & \multirow{2}{*}{$<.001$} \\
\hline & & 2 & 226.5 & & \\
\hline \multirow{2}{*}{$\mathrm{H}_{2 \mathrm{a}}$} & \multirow{2}{*}{ Co-workers perform their work effectively } & 1 & 268.9 & \multirow{2}{*}{26113.5} & \multirow{2}{*}{.001} \\
\hline & & 2 & 231.2 & & \\
\hline \multirow{2}{*}{$\mathrm{H}_{2 \mathrm{~b}}$} & \multirow{2}{*}{$\begin{array}{l}\text { Employees always share information that } \\
\text { can help to improve the skills of co-workers }\end{array}$} & 1 & 257.0 & \multirow{2}{*}{27965.0} & \multirow{2}{*}{.105} \\
\hline & & 2 & 238.1 & & \\
\hline \multirow{2}{*}{$\mathrm{H}_{2 \mathrm{~d}}$} & \multirow{2}{*}{$\begin{array}{l}\text { Employees know that their work is } \\
\text { important }\end{array}$} & 1 & 249.8 & \multirow{2}{*}{29852.5} & \multirow{2}{*}{.705} \\
\hline & & 2 & 245.4 & & \\
\hline \multirow[b]{2}{*}{$\mathrm{H}_{2 \mathrm{c}}$} & \multirow{2}{*}{$\begin{array}{l}\text { Employees always, when seeing an } \\
\text { opportunity, put forward work improvement } \\
\text { proposals }\end{array}$} & 1 & 245.2 & \multirow[b]{2}{*}{29833.0} & \multirow[b]{2}{*}{.774} \\
\hline & & 2 & 248.6 & & \\
\hline \multirow{2}{*}{$\begin{array}{l}\mathrm{H}_{2 \mathrm{c}} \\
\text { control }\end{array}$} & \multirow{2}{*}{$\begin{array}{l}\text { The company management always explains } \\
\text { the feasibility of introducing employee } \\
\text { proposals }\end{array}$} & 1 & 257.0 & \multirow{2}{*}{27484.5} & \multirow[b]{2}{*}{.087} \\
\hline & & 2 & 236.1 & & \\
\hline \multirow{2}{*}{$\mathrm{H}_{2 \mathrm{f}}$} & \multirow{2}{*}{$\begin{array}{l}\text { Relations among co-workers in the } \\
\text { company are professional and friendly }\end{array}$} & 1 & 248.2 & \multirow{2}{*}{30485.5} & \multirow{2}{*}{.979} \\
\hline & & 2 & 247.9 & & \\
\hline
\end{tabular}

Sig. at a level of $p \leq 0.05$

The results show that the management of high-performing SMEs has the capabilities to create a workplace that differs significantly by having the following characteristics of an engaging workplace: (1) employees want to work for the current company in the long term, and (2) co-workers perform their work effectively. Thus, the $\mathrm{H}_{2} \mathrm{e}$ and $\mathrm{H}_{2}$ a parts of the $\mathrm{H}_{2}$ hypothesis are accepted. Meanwhile, there is no significant difference in the following characteristics of an engaging workplace: (1) employees always share information that can 
help to improve the skills of co-workers, (2) employees know that their work is important, (3) employees always, when seeing an opportunity, put forward work improvement proposals, (4) relations among co-workers in the company are professional and friendly. Therefore, the $\mathrm{H}_{2} \mathrm{~b}, \mathrm{H}_{2} \mathrm{~d}, \mathrm{H}_{2} \mathrm{c}$ and $\mathrm{H}_{2} \mathrm{f}$ parts of the $\mathrm{H}_{2}$ hypothesis are rejected. The $\mathrm{H}_{2} \mathrm{c}$ part of the hypothesis was controlled by the explanation to employees of the feasibility of introducing their proposals. The results show that there is a trend ( $p$-value .087) for the management of the first group of SMEs to put more effort into the explanation of the feasibility of introducing employee proposals.

Additionally, the results are controlled by the experience of employees in their current job position and at their present age, since more senior employees are better fitted to tasks than less senior ones. Therefore, more senior employees exhibit higher productivity and earnings on average (Harris and Holmstrom, 1982). The results are presented in Table 4.

Table 4

\section{The results of control items}

\begin{tabular}{llcccc}
\hline \multirow{2}{*}{ No. } & \multicolumn{1}{c}{ Item } & $\begin{array}{c}\text { Group } \\
\text { of SMEs }\end{array}$ & $\begin{array}{c}\text { Mean } \\
\text { rank }\end{array}$ & U & p-value \\
\hline \multirow{2}{*}{ Control } & \multirow{2}{*}{ Experience in the current job position } & 1 & 236.8 & 27894.5 & \multirow{2}{*}{.319} \\
\hline \multirow{2}{*}{ Control } & \multirow{2}{*}{ Age of employees } & 2 & 249.5 & \\
\cline { 3 - 5 } & & 2 & 226.0 & 25431.5 & \multirow{2}{*}{.018} \\
\hline
\end{tabular}

Sig. at a level of $p \leq 0.05$

The control results show that there is no significant difference between the first group and second group of SMEs in terms of employees' experience in their current job position; $p$ value .319. Experience in the current job position is 8 years on average, SDs 6.9 and 5.8, respectively. However, there is a significant difference in employee age between the first group and the second group of SMEs: 38 years (SD 10.8) and 40 years on average (SD 11.0), respectively.

\section{DISCUSSION}

In this study, the differentiating characteristics of managerial capabilities to create a highperformance workplace in SMEs are explored. First, it was found that in high-performance SME workplaces, managers supply employees with everything they need to achieve high job results; management has a respectful attitude toward employees; employee salary is fully in line with the level of professional skills; management supports the development of employees' professional skills; co-workers perform their work effectively; employees work shorter job shifts; and they intend to work for their current company in the long term. Therefore, there are seven differentiating characteristics of the managerial capabilities needed to create a high-performance workplace in an SME. Supplementary to 
Buckingham's and Coffman's (1999) characteristics of the high-performance workplace, in this study, it was found that employees' salaries according to their level of professional skills, shorter job shifts and willingness to work for the current company in the long term might also characterise the strength of a workplace. The findings of this study contribute to EO literature and particularly to the top management characteristics that lead a company to high performance (Lumpkin and Dess, 1996; Eisenhardt, 2013; Buckingham and Coffman, 1999; Yucel, 2011; Helfat and Peteraf, 2015; Simsek et al., 2010; Deb and Wiklund, 2017).

Second, the results show that there is no significant difference in the following workplace characteristics of SMEs: (1) employees' remuneration is based on pay-for-performance, (2) employees always receive recognition from company management for a well-performed job, (3) employees know what is expected from them, (4) employees are doing the job they can do best, (5) employees regularly receive a performance assessment from the management of the company, (6) employees always share information that can help to improve the skills of co-workers, (7) employees know that their work is important, (8) employees always, when seeing an opportunity, put forward work improvement proposals, (9) relations among co-workers in the company are professional and friendly. These are the necessary characteristics for a workplace to be capable of competing in the market. However, these characteristics are unlikely to differentiate high-performance companies from their competitors.

Third, the control variables show that there is no significant difference between employees of both groups of SMEs in terms of experience in a current job position; the average is 8 years. Moreover, given that the employees of the first group of SMEs are younger by 2 years on average, the higher performance of the first group was not influenced by differences in years of experience and the fact that more senior employees are better fitted to tasks than less senior ones, and more senior employees exhibit higher productivity and earnings on average (Harris and Holmstrom, 1982).

Overall, the results show that apart from the nine common characteristics of SMEs' workplaces, high-performing SMEs possess seven differentiating characteristics which give them a competitive advantage, due to resource heterogeneity (Peteraf, 1993) and the capability to exploit it (Barney, 1995). Moreover, the managerial capabilities to create a high-performance workplace comprise a knowledge-based resource which positively influences a company's performance. Thus, this study supplements the findings of Wiklund and Shepherd (2003) that knowledge-based resources are positively related to a company's performance and EO enhances this relationship. In general, it is argued that SMEs that have the workplace characteristics included in this study have at least a temporary competitive advantage because socially complex resources and capabilities are much more difficult to imitate (Barney, 1995), and managerial capabilities to create a highperformance workplace are valuable and rare. 


\section{CONCLUSIONS}

1. This study attempted to determine the managerial capabilities necessary to create a high-performance workplace in SMEs. The managerial capabilities to create strong workplace performance exist where: (1) management has a respectful attitude toward employees, (2) management supports the development of employees' professional skills, (3) employees are provided with everything they need to achieve high job results, (4) employees want to work for the company in the long term, (5) remuneration of employees is fully in line with their level of professional skills, (6) co-workers perform their work effectively, (7) employees work shorter job shifts. These elements constitute the knowledge-based resources of highperformance SMEs, giving them, at a minimum, a temporary competitive advantage.

2. Only some of the differentiating characteristics of managerial capabilities were included in this study. Therefore, further research might investigate other characteristics such as team building, employee selection, the decision-making process, design thinking and other industry-related characteristics that might positively influence performance and lead SMEs to a competitive advantage.

\section{LIMITATIONS}

This study explored the differentiating characteristics of the managerial capabilities of SMEs in the forestry industry in Latvia, and only manual workers were included. The creation of a high-performance workplace for knowledge workers (Drucker, 1959; 2002) might require different managerial capabilities. The findings of such a study might differ from those of this study.

The sample size of SMEs included in this study consists of 47 companies. A bigger sample size of companies and a study of other industries or in other countries may reveal additional characteristics of managerial capabilities or amend the findings of this study. This is because two trends were noticed in the control questions: (1) the management of the first group of SMEs gave more attention to explaining the requirements for work and its importance ( $p$-value .074), and (2) the management of the first group of SMEs put more effort into explaining the feasibility of introducing employee proposals ( $p$-value .087). 


\section{REFERENCES}

1. Aguinis, H. (2009), Performance Management, Second Edition, Pearson Education Inc., Upper Saddle River, New Jersey, ISBN 0-13-814691-8.

2. Amankwah-Amoah, J., Danso, A. and Adomako, S. (2019), "Entrepreneurial orientation, environmental sustainability and new venture performance: Does stakeholder integration matter?", Business Strategy and the Environment, Vol. 28, No. 1, pp. 79-87.

3. Andersén, J., Jansson, C. and Ljungkvist, T. (2020), "Can environmentally oriented CEOs and environmentally friendly suppliers boost the growth of small firms?", Business Strategy and the Environment, Vol. 29, No. 2, pp. 325-334.

4. Armstrong, M. (2012), Armstrong's Handbook of Reward Management Practice, Fourth Edition, Replika Press Pvt Ltd, E-ISBN 9780749466480.

5. Ayyagari, M., Demirguc-Kunt, A. and Maksimovic, V. (2014), "Who creates jobs in developing countries?”, Small Business Economics, Vol. 43, No. 1, pp. 75-99.

6. Bandiera, O., Barankay, I. and Rasul, I. (2010), "Social incentives in the workplace", The Review of Economic Studies, Vol. 77, No. 2, pp. 417-458.

7. Barney, J. B. (1995), "Looking inside for competitive advantage", The Academy of Management Executive (1993-2005), Vol. 9, No. 4, pp. 49-61.

8. Black, S. E., Lynch L. M. (2001), "How to compete: The impact of workplace practices and information technology on productivity", The Review of Economics and Statistics, Vol. 83, No. 3, pp. 434-445.

9. Black, S. E., Lynch, L. M. (2004), "What's driving the new economy?: The benefits of workplace innovation”, The Economic Journal, Vol. 114, No. 493, pp. F97-F116.

10. Buckingham, M., Coffman, C. (1999), First, Break All the Rules: What the World's Greatest Managers Do Differently, The Gallup Organization, Simon and Schuster, New York.

11. Chatain, O. (2010), "Value creation, competition, and performance in buyer-supplier relationships”, Strategic Management Journal, Vol. 32, No. 1, pp. 76-102.

12. Cronbach, L. J. (1951), "Coefficient alpha and the internal structure of tests", Psychometrika, Vol. 16, No. 3, pp. 297-334.

13. Deb, P., Wiklund, J. (2017), "The Effects of CEO founder status and stock ownership on entrepreneurial orientation in small firms", Journal of Small Business Management, Vol. 55 , No. 1, pp. 32-55. 
14. Doeringer, P. B., Evans-Klock, C. and Terkla, D. G. (1998), "Hybrids or hodgepodges? Workplace practices of Japanese and domestic startups in the United States", ILR Review, Vol. 51, No. 2, pp. 171-186.

15. Drucker, P. F. (1959), Landmarks of Tomorrow, Harper and Row, New York.

16. Drucker, P. F. (2002), The Effective Executive, HarperCollins Publishers Inc., New York.

17. Eisenhardt, K. M. (2013), "Top management teams and the performance of entrepreneurial firms”, Small Business Economics, Vol. 40, No. 4, pp. 805-816.

18. Eurostat (2020), "Small and medium-sized enterprises (SMEs)", available at: https://ec.europa.eu/eurostat/web/structural-business-statistics/structural-businessstatistics/sme (accessed 17 February 2020).

19. Fox, J. B., Scott, K. D. and Donohue, J. M. (1993), “An investigation into pay valence and performance in a pay-for-performance field setting", Journal of Organizational Behavior, Vol. 14, No. 7, pp. 687-693.

20. Gielen, A. C., Kerkhofs, M. J. M. and van Ours, J. C. (2010), "How performance related pay affects productivity and employment", Journal of Population Economics, Vol. 23, No. 1, pp. 291-301.

21. Hansen, M. H., Perry, L. T. and Reese, C. S. (2004), “A Bayesian operationalisation of the resource-based view”, Strategic Management Journal, Vol. 25, No. 13, pp. 1279-1295.

22. Harris, M., Holmstrom, B. (1982), “A theory of wage dynamics”, Review of Economic Studies, XLIX, pp. 315-333.

23. Helfat, C. E., Peteraf, M. A. (2015), "Managerial cognitive capabilities and the microfoundations of dynamic capabilities", Strategic Management Journal, Vol. 36, No. 6, pp. 831-850.

24. Ichniowski, C., Shaw, K. and Prennushi, G. (1997), "The effects of human resource management practices on productivity: a study of steel finishing lines", The American Economic Review, Vol. 87, No. 3, pp. 291-313.

25. Jakhar, S. K. (2017), "Stakeholder engagement and environmental practice adoption: the mediating role of process management practices", Sustainable Development, Vol. 25, No. 1, pp. 92-110.

26. Knight, G. (2000), "Entrepreneurship and marketing strategy: the SME under globalisation", Journal of International Marketing, Vol. 8, No. 2, pp. 12-32.

27. Lazear, E. P. (1986), "Salaries and piece rates", The Journal of Business, Vol. 59, No. 3, pp. $405-431$. 
28. Lazear, E. P. (2000), "Performance pay and productivity", The American Economic Review, Vol. 90, No. 5, pp. 1346-1361.

29. Leoni, R. (2012), "Workplace design, complementarities among work practices, and the formation of key competencies: Evidence from Italian employees", Industrial and Labor Relations Review, Vol. 65, No. 2, pp. 316-349.

30. Lumpkin, G. T., Dess, G. G. (1996), "Clarifying the entrepreneurial orientation construct and linking it to performance", The Academy of Management Review, Vol. 21, No. 1, pp. $135-172$.

31. McEvily, S. K., Chakravarthy, B. (2002), "The persistence of knowledge-based advantage: an empirical test for product performance and technological knowledge", Strategic Management Journal, Vol. 23, No. 4, pp. 285-305.

32. Miller, D., Shamsie, J. (1996), "The resource-based view of the firm in two environments: the Hollywood film studios from 1936 to 1965", The Academy of Management Journal, Vol. 39, No. 3, pp. 519-543.

33. Nair, A. K. S., Bhattacharyya, S. S. (2019), "Mandatory corporate social responsibility in India and its effect on corporate financial performance: Perspectives from institutional theory and resource-based view", Business Strategy and Development, Vol. 2, No. 2, pp. 106-116.

34. Newbert, S. L. (2008), "Value, rareness, competitive advantage, and performance: a conceptual-level empirical investigation of the resource-based view of the firm", Strategic Management Journal, Vol. 29, No. 7, pp. 745-768.

35. Pankaj, G., Rivkin, J. W. (2006), “Creating competitive advantage”, Harvard Business School background note 798-062, January 1998 (revised February 2006).

36. Penrose, E. (1959), The Theory of the Growth of the Firm, Fourth Edition, Oxford University Press Inc., New York, 2009, ISBN 978-0-19-957384-4.

37. Peteraf, M. A. (1993), "The cornerstones of competitive advantage: a resource-based view”, Strategic Management Journal, Vol. 14, No. 3, pp. 179-191.

38. Peteraf, M. A., Barney, J. B. (2003), "Unraveling the resource-based tangle", Managerial and Decision Economics, Vol. 24, No. 4, pp. 309-323.

39. Poudel, K. P., Carter, R. and Lonial, S. (2019), “The impact of entrepreneurial orientation, technological capability, and consumer attitude on firm performance: A multi-theory perspective", Journal of Small Business Management, Vol. 57, No. S2, pp. 268-295.

40. Shearer, B. (2004), "Piece rates, fixed wages and incentives: Evidence from a field experiment”, Review of Economic Studies, Vol. 71, No. 2, pp. 513-534. 
41. Simsek, Z., Heavey, C. and Veiga, J. J. F. (2010), "The impact of CEO core self-evaluation on the firm's entrepreneurial orientation”, Strategic Management Journal, Vol. 31, No. 1, pp. 110-119.

42. Smith, P. J. (2003), "Workplace learning and flexible delivery", Review of Educational Research, Vol. 73, No. 1, pp. 53-88.

43. Taber, K. S. (2018), “The use of Cronbach's alpha when developing and reporting research instruments in science education", Research in Science Education, Vol. 48, pp. 1273-1296.

44. van den Bosch, F. A. J., van Wijk, R. (2001), "Creation of managerial capabilities through managerial knowledge integration: a competence-based perspective”, in Sanchez, R. (Ed.), Knowledge Management and Organizational Competence, Oxford University Press.

45. Wales, W. J., Covin, J. G. and Monsen, E. (2020), “Entrepreneurial orientation: The necessity of a multilevel conceptualization", Strategic Entrepreneurship Journal, Vol. 14, No. 4, pp. 639-660.

46. Wiklund, J., Shepherd, D. (2003), “Knowledge-based resources, entrepreneurial orientation, and the performance of small and medium-sized businesses", Strategic Management Journal, Vol. 24, No. 13, pp. 1307-1314.

47. World Bank (2020), "World Development Report 2020: Trading for development in the age of global value chains", World Bank, Washington, D.C., doi: 10.1596/978-1-46481457-0, license: Creative Commons Attribution CC BY 3.0 IGO.

48. Yucel, I. (2011), “Entrepreneurial orientation, executives' individualism and firm performance: the moderating role of executives' individualism", Far East Journal of Psychology and Business, Vol. 5, No. 3, pp. 63-77. 


\section{The role of informal institutions in the relationship between social capital and international entrepreneurial entry}

MUHAMMAD UMER SHAHID

\section{ABSTRACT}

Purpose. The goal of the current study is to gain an understanding of how various informal institutional elements such as trust and corruption control affect the relationship between entrepreneurial ventures' social capital and their ability to reach the worldwide market.

Design/Methodology/Approach. The paper draws on internationalization and social capital data from the Global Entrepreneurship Monitor (GEM), which includes 482,257 observations from 44 countries between 2003-2013, with a focus on early-stage entrepreneurs (as defined by the TEA index) who are involved in significant international entrepreneurial entry. A multi-level modelling strategy is employed for analyzing the various hypotheses by using STATA.

Findings. Possessing a high level of social capital makes it easier to start a business at the international stage. And further, informal institutional variables, i.e., trust and control of corruption, positively moderate the association between social capital and international entrepreneurial entry; thus, societies where honesty prevails and corruption is controlled facilitate better international entrepreneurial entry.

Limitations/Implications. The study is based on informal institutions, i.e., the variable trust taken from the World Value Survey (WVS) and the variable control of corruption by using a large sample size and multi-level modelling from World Governance Indicators, which demonstrates the importance of institutions as systems of shared meanings and noncodified standards. However, there are a number of other informal institutional indicators to examine that could have an impact on the relationship at the individual level. Implications from a theoretical perspective explain advancement of the institutional perspective as a conceptual framework for explaining international entrepreneurial activity and, further, the study empirically validates the significance of informal institutional environmental factors in the context of international entrepreneurship. 
Originality/Value. With the increasing interest of scholars in using the institutional approach and the availability of limited empirical studies in light of informal institutions, using a multi-level approach the current study empirically investigates the role of trust and control of corruption in the context of social capital and international entrepreneurship.

Keywords: social capital, internationalization, international entrepreneurship, informal institutions

\section{INTRODUCTION}

There is a surge of literature in the field of international entrepreneurship that highlights the significance of the idea of social capital as an important descriptive constituent in the process of internationalization of an entrepreneurial venture (Shahid, 2020; Puthusserry et al., 2020). And various empirical studies have also highlighted the importance of networks of relationships, which smoothen and also accelerate the internationalization process of new ventures (Sedziniauskiene et al., 2019). Social capital helps in acquiring critical knowledge required in achieving access to international markets (Welch, 2004). Further, in economies where the institutional structure is characterized by deeply embedded norms, values and codes of conduct, entrepreneurial social capital appears to play a significant role in helping entrepreneurs to cope with constraints present in the culture of a society.

The continued reflection on firms' globalization and their efforts in internationalization (Inouye et al., 2020) has shifted the interests of scholars towards studying the role of institutions in this process. Literature on firms entering the international market is gaining significant attention from policy-makers and academics. This is happening due to a transformation taking place in various business practices along with changes in informal institutional environmental factors.

Based on mixed empirical findings reported in the literature on the relationship between informal institutions and international entry (Muralidharan and Pathak, 2020; Chang and Rosenzweig, 2001; Luo, 2001) as well as a meta-analysis, a study conducted by Tihanyi et al. (2005) reported insignificant statistical evidence regarding the relationship between informal institutions and international entry and, further, highlighted the need for substantial research in order to fully understand the context of informal institutions. In light of this assumption, the study tried to report positive empirical findings on the moderating role played by informal institutions in the context of social capital and international entry, which is the objective of this study as well.

In the context of international entrepreneurship research, the limited use of institutional theory has been documented. Peiris et al. (2012) highlighted that only four studies have employed institutional theory in their theoretical frameworks for understanding the context of international entrepreneurship (in our case, international entrepreneurial entry). The institutional environment basically explains two sides of the coin, i.e., either it facilitates or constrains various entrepreneurial aspirations, intentions and opportunities, which further 
affects the speed and scope of new ventures' international entrepreneurial entry into foreign markets (Freixanet and Renart, 2020). Scholars have mostly discussed formal institutions in the context of international entrepreneurship, leaving a gap to explore the role of informal institutions (i.e., trust and control of corruption) in order to provide descriptions of this phenomenon as well (Szyliowicz and Galvin, 2010).

Informal institutions are defined as values, norms and codes of conduct that are embedded deeply in the culture of a society, and these cultural traditions impact the patterns of various entrepreneurial actions. Further, Welter and Smallbone (2003) also emphasized that these informal institutions, due to their property of being deeply embedded in society, are quite resilient to change and at the same time slow down the process due to their path dependence. In the study, we have assumed that various societal norms and values have a significant role to play in the context of international entrepreneurship. This leads to our research question, in which we examine how societal values, in our case trust and control of corruption, which we defined as informal institutions, predict international entrepreneurial entry.

Following the introduction, the paper is structured as follows. First, a brief overview of literature on social capital, international entrepreneurial entry, and informal institutions in the context of new ventures is provided and hypotheses are listed. Secondly, the methodology of the research is explained, and the results are presented, and finally the article concludes with implications for the context of social capital and international entrepreneurial entry and highlights that the value of informal institutions cannot be overstated.

\section{LITERATURE}

\section{Social Capital and International Entrepreneurial Entry}

Generally, social capital can facilitate the entry of an entrepreneurial venture into the international market and its success (Shahid, 2020; Granovetter, 1973). As firms initiate, deepen and establish their contacts while in the process of internationalization, the activity of an entrepreneurial firm can be viewed as developing and accessing social capital (Johanson and Vahlne, 2006). Various scholars (Yli-Renko et al., 2002) have explained the concept of social capital and highlighted that it is a significant contributor in a firm's acquisition of knowledge, market competitiveness and internationalization. Yet when considering the significance of entrepreneurial orientation in the context of internationalization, most firms suffer initially in achieving a better performance due to the absence of a valuable resource like social capital (Hitt et al., 2001). The concept of social capital is defined as "an aggregate of actual and potential resources possessed by the entrepreneurial ventures from within their network of relationships" (Nahapiet and Ghoshal, 1998) and has a significant role to play in the process of international 
entrepreneurial entry (Chetty and Agndal, 2007). As ventures in their initial stages are subjected to the liability of being small and new, it becomes difficult for them to survive and move toward internationalization. Further, for new ventures one of the effective means to develop internationally is through the acquisition of valuable resources available from within the network of relationships (Jiang et al., 2018), instead of focusing on acquiring resources through internationalization (Oviatt and McDougall, 1994).

In order to determine the extent of international entrepreneurial entry, access to tacit knowledge is crucial (Vida, 2000), which in turn can be acquired from, within and through the network of relationships. Further, entrepreneurial social capital also facilitates in selecting the right market to enter and provides various suitable choices of entry mode when small ventures plan for their international entrepreneurial entry. There is also a rapid increase in accepting the influence of entrepreneurial social relationships on the internationalization of small firms. In this context it has been found that specifically access to external sources of social capital (i.e., buyer-supplier) has a significant role to play in the process of exporting to the international market (Shahid, 2020; Bonaccorsi, 1992). Therefore, access to the network of relationships facilitates new ventures in expanding their social capital (Yan and Guan, 2018), and at the same time provision of indirect access to resources facilitates in reducing the transaction costs incurred in case of exchange and production (Chetty and Agndal, 2007). We postulate the following based on the significance of social capital in the context of international entrepreneurial entry:

H1: Social capital and international entrepreneurial entry possess a positive link.

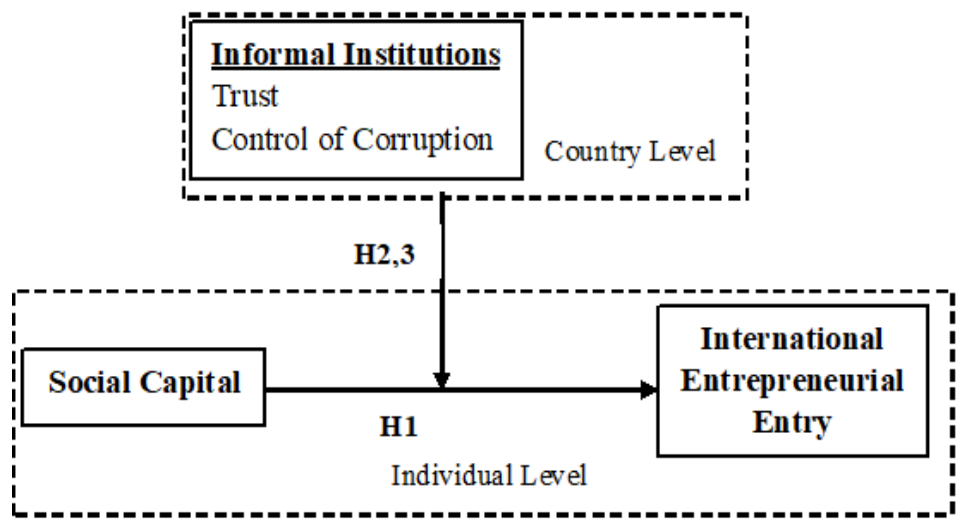

Figure 1 Research model

\section{Social Capital, International Entrepreneurial Entry and Informal Institutions}

Relatively well-grounded rules, community-based norms and cognitive structures explain the institutional environment of a country (Scott, 1995), which further assists in defining 
"rules of the game" (North, 1990: p. 1) in society. These institutions, in the form of structural frameworks, shape the governance of making economic decisions and the activities to be carried out in the marketplace (Szyliowicz and Galvin, 2010; Yeung, 2002). Like any other economic activity, entrepreneurship has been discussed in light of both formal institutions (rules and regulations) and informal institutions such as norms and values (Baumol, 1990). Generally, entrepreneurs are indeed embedded in the institutional environment and are the products of their socio-cultural environment (Jones and Conway, 2004). There is a mixed set of findings when it comes to deciding about international entry in the varying institutional environment context; several studies have found that international entry is negatively affected by the informal institutional environment (e.g. Erramilli and Rao, 1993), while a few have found a positive relationship (e.g. Anand and Delios, 1997), and a few others have found either a mixed (e.g. Chang and Rosenzweig, 2001) or insignificant (e.g. Luo, 2001) impact. But in the current study, we focused on trust and control of corruption as components of the informal institutional environment that have a positive impact on international entry. As scholars have also highlighted, prevalence of a high level of trust in institutions and amenability with norms can further lead to lowering the level of corruption in a society (Kay and Hagan, 2003; Tantardini and Garcia-Zamor, 2015). Building on this point, we further explain our informal institutional variables, i.e., trust and corruption, in detail below.

\section{Trust}

In recent years, there has been an increasing interest among entrepreneurship scholars in studying the role played by trust (Hohmann and Welter, 2005; Welter and Smallbone, 2006), leading towards identifying the cause of its growing popularity in entrepreneurship. Various studies have identified trust as a crucial component when it comes to starting new businesses; this includes research on the relationship with business angels and venture financiers (Maxwell and Levesque, 2011; Startling et al., 2011), franchising (Davies et al., 2011), or the buyer-supplier relationship (Sengun and Nazli Wasti, 2009), and specifically the role played by trust in the process of internationalization of new ventures (Fink and Kessler, 2010). Some scholars see trust as an essential prerequisite for various enterpriserelated procedures such as information and communication technology adoption (Beckinsale et al., 2011) and knowledge transfer (Lockett et al., 2008). Most of the time, discussion related to trust in the context of entrepreneurship focuses on two major areas, networks and social capital; Brunetto and Farr-Wharton (2007) mentioned these social relations as being considered a proxy for personal trust. Some scholars (Anderson et al., 2007; Kim and Aldrich, 2005) believe that trust renders support for social network relations, whereas networks provide significant support in identifying and creating opportunities (Jack and Anderson, 2002). Notably, in the internationalization of new ventures, trustful relationships serve as a facilitator in maintaining and developing longlasting relationships (Rodrigues and Child, 2012). Further, these trust-centred relations are helpful in reducing the transaction cost associated with monitoring and consultations 
(Blomqvist et al., 2008). Various scholars (Brunetto and Farr-Wharton, 2007; Rodrigues and Child, 2012) have mentioned considerable advantages associated with trust-based relations; they provide motivation, relevant knowledge, underlying opportunities, and protection against the associated risks of being small and new to the international market.

Situations where formal constraints are lacking or missing give rise to the significance of informal institutions because in such a context, a specific segment and/or a particular societal group is ignored by mainstream society. Informal social contacts have frequently played a significant role by assisting entrepreneurs in various tasks such as managing resources and by providing guidance through highly bureaucratic systems, for coping with the various restrictions imposed by them (Ledeneva, 1998; Smallbone and Welter, 2001). This further highlights the significance of social capital, which is embedded in informal institutions, in order to enter the international market and for the subsequent expansion and progress of a business. Further, the concept of new venture internationalization is broadly understood by the theory of internationalization, which argues that the impact of various social, economic and technological factors forces new firms to venture into the international market immediately after their inception (Muralidharan and Phathak, 2017). And firms under this model do not follow the gradual incremental process of internationalization (McDougall and Oviatt, 2000).

From the perspective of McKeever, Anderson and Jack (2014), social capital has been considered as an important influential factor in the context of entrepreneurship. Social capital is characterized by various social contacts that allow entrepreneurs to cooperate with other individuals in order to help their businesses to enter international markets. In this viewpoint, the entrepreneurial context encompasses various resources and contacts which are subjected to change while going through the various phases of entrepreneurial processes, i.e., entering the international market will require a different level of contacts. As initially it is difficult for entrepreneurs to predict which contacts and institutions will be helpful for them, an informal institutional environment with a high level of trust will reduce the uncertainties in contacts. Further, in the internationalization of a venture, entrepreneurs are persistent in building trust and cooperation with their social contacts, which also helps them in mobilizing various resources (Chetty and Agndal, 2007; Cheung, 2004; Oviatt and McDougall, 2005; Rodrigues and Child, 2012). We postulate the following based on the relevance of trust as an informal institution in the interaction between social capital and international entrepreneurial entry:

H2: Trust positively moderates the association between social capital and international entrepreneurial entry.

\section{Control of Corruption}

Corruption tends to appear in studies related to the societal institutional environmental context (Tantardini and Garcia-Zamor, 2015). Inefficiency in institutions might affect entrepreneurship (Douhan and Henrekson, 2010), including the informal factor of 
corruption, which can affect the perception of an entrepreneur and his motivation for establishing a new business. Furthermore, corruption favours strong established firms which may take advantage of various public resources in order to increase their benefits; at the same time, it creates hurdles for newly established businesses. Additionally, in societies where individuals tend to move away from legal processes, it eventually gives rise to illegal and unethical behaviour, and with the passage of time it becomes a normal practice followed by individuals in general (Axelrod, 1986). In a similar context, this behaviour further flourishes as a permanent social norm in society, forcing individuals to opt for unlawful business practices as a normal way of getting their activities done (Paxton, 1999). On the contrary, control of corruption being analyzed as an informal institution tends to improve entrepreneurs' perception of the incentives associated with establishing new businesses locally or internationally (Aparicio et al., 2016). So the point is that a large amount of corruption control mechanisms is mostly present in developed countries as opposed to developing countries (Siddiqui, 2019; Escandon-Barbosa, 2019). Further, the importance of controlling this informal institutional factor of corruption can be seen in the creation of new businesses with higher added value (Escandon-Barbosa, 2019).

Generally, it instinctively seems apparent that there exists a strong link between social capital and corruption at the institutional level, explaining the scenario in which people tend to be more honest when experiencing a lower level of corruption (Gorsira et al., 2018; Bjørnskov, 2003), even though in research on social capital and control of corruption, the direction of causality is less clear compared to studies related to their direct association. Therefore, corruption is considered lower in a society where honesty and trust prevail and vice versa (Paldam and Svendsen, 2002; Uslaner, 2001). Apart from the distortion in individuals' perception and the inefficiency in the bureaucratic governance structure created by corruption (Méon and Sekkat, 2005), it can have some positive effects on entrepreneurial activity (i.e., international entrepreneurial entry in our case) when it is controlled (Alvarez and Urbano, 2011; Wennekers et al., 2005) by the governing institutions. Further, one meta-analytic study specifically explained the moderating role of control of corruption (Doucouliagos and Ulubasoglu, 2008) in the growth and development of society (Kaufmann et al., 2008). Therefore, considering its positive aspects, control of corruption in society will increase the likelihood of future entrepreneurs taking a larger portion of the revenues they generate, which will further motivate them to carry out better international entrepreneurial entry (Alvarez and Urbano, 2011). Therefore, it stands to reason that an improvement in corruption control should have a greater impact in a situation where corruption is high than where it is low (Anokhin and Schulze, 2009). We postulate the following based on the relevance of corruption control as an informal institution in the interaction between social capital and international entrepreneurial entry:

H3: Control of corruption positively moderates the association between social capital and international entrepreneurial entry. 


\section{METHODOLOGY}

In our study the theoretical framework consists of two main levels: an individual level and a country level. This is also depicted in Figure 1. We tested the three hypotheses related to social capital and its effect on international entrepreneurial entry with the moderating role of informal institutional variables in combination, which makes our theoretical framework a multi-design model. The Global Entrepreneurship Monitor's adult population survey (APS), which provides data that is reliable, valid and rich (Shahid, 2020; Reynolds et al., 2005), was used for conducting cross-country research, to observe the behaviour of an entrepreneur at an individual level, i.e., social capital and international entrepreneurial entry. GEM provides significant data on social capital and foreign market entry in an adult population survey, and we used data from 2002-2013 for our study which is also publicly available on its official website (www.gemconsortium.org). The Global Entrepreneurship Monitor initiative began in the late 1990s with a goal of gathering individual-level (APS) data from various nations around the world and it is now made available to the public every year (Bosma, 2013). Each country is represented by a sample of at least 2000 people (aged 18 to 64) who are interviewed by phone or in person on a regular basis. International entrepreneurship research mainly relies on GEM due to the depth and richness of its data (Bowen and De Clercq, 2008; McMullen et al., 2008; Elam and Terjesen, 2010).

For our informal institutional variables at the country level, the data for trust is taken from the World Values Survey (WVS) over the period of 2002 to 2013, which is covered in wave 4 to wave 6 . And further, the data for control of corruption is taken from World Governance Indicators (WGI), a project of the World Bank (World Bank, 2004; 2007). Further, we merged the individual-level data with the country-level data, which provided 482,257 observations and covered 44 countries from 2002 to 2013. Details of mean values for each participating country are provided in Table 1 . More importantly, the overall data is anchored by GEM in such a way that if relevant data for individual-level variables is available for a particular country in a particular year in GEM, then the data is gathered for country-level variables, i.e., control of corruption and trust, from WGI and WVS sources respectively for the same country in a particular year as well.

\section{Individual-level Dependent Variable International Entrepreneurial Entry}

International entrepreneurial entry is employed as the dependent variable in the study, with the early-stage entrepreneur being asked "to estimate the proportion of clients who live outside his/her country" (Muralitharan and Pathak, 2017; Shahid, 2020). 


\section{Descriptive Statistics}

\begin{tabular}{|c|c|c|c|c|c|}
\hline & $\mathbf{N}$ & $\begin{array}{l}\text { Mini- } \\
\text { mum }\end{array}$ & $\begin{array}{l}\text { Maxi- } \\
\text { mum }\end{array}$ & Mean & $\begin{array}{c}\text { Std. } \\
\text { Deviation }\end{array}$ \\
\hline $\begin{array}{l}\text { International } \\
\text { entry }\end{array}$ & 482257 & .00 & 1.00 & .0395 & .19473 \\
\hline Social capital & 482257 & -2 & 1 & .37 & .490 \\
\hline Age & 482257 & 18 & 64 & 40.59 & 12.656 \\
\hline Gender & 482257 & 1 & 2 & 1.50 & .500 \\
\hline Education & 482257 & -2 & 1720 & 943.58 & 603.390 \\
\hline Income & 482257 & 1 & 3 & 2.05 & .808 \\
\hline Trust & 44 & 4.1 & 73.7 & 23.836 & 14.3881 \\
\hline $\begin{array}{l}\text { Control of } \\
\text { corruption }\end{array}$ & 44 & -1.132 & 2.552 & 0.772 & 0.938 \\
\hline $\begin{array}{l}\text { GDP per } \\
\text { capita_ppp }\end{array}$ & 44 & 2998 & 77429 & 26026.30 & 12345.035 \\
\hline $\begin{array}{l}\text { Zscore (GDP } \\
\text { growth) }\end{array}$ & 44 & -1.48339 & 3.94606 & -.1384008 & .94336885 \\
\hline $\begin{array}{l}\text { Population_tot } \\
\text { al }\end{array}$ & 44 & 3331043 & 1350695000 & 107143851.78 & 229250407.073 \\
\hline $\begin{array}{l}\text { Population } \\
\text { growth }(\%)\end{array}$ & 44 & -98.926 & 12539.257 & 1212.632 & 2451.845 \\
\hline
\end{tabular}

GEM classifies entrepreneurs into three broad categories. The first category comprises "nascent entrepreneurs", which includes those individuals who are in the process of making an attempt to start a business (i.e., in the conception stage) and have expectations of full or part-time ownership. The second category comprises "new entrepreneurs", who are defined as "startup owner/managers who have paid wages for 3 to 42 months". Finally, the third category comprises "established entrepreneurs", who are defined as "individuals who have been in a company for more than 42 months and have paid wages". According to the TEA (Total Entrepreneurial Activity), we focused on the early-stage entrepreneur index (as nascent and new entrepreneurs) involved in a significant amount of foreign trade. We explicitly measured foreign entrepreneurial entry as whether at least $25 \%$ of their customers were located overseas (Shahid, 2020; Chen et al., 2018). Only those businesses with at least a quarter of their customers residing overseas (i.e., 25\%) were chosen. 


\section{Country-level Predictor Variable Informal Institutions (Trust and Control of Corruption)}

Previously, various studies have used trust and control of corruption at the country level (Alvarez and Urbano, 2011; Anokhin and Schulze, 2009; Hohmann and Welter, 2005; Welter and Smallbone, 2006), and mainly two informal institutional variables, i.e., trust and control of corruption at the country level, are used in our study as well. The data for trust is obtained from the WVS over the period of 2001 to 2013. In order to measure the variable trust, WVS uses the following question: "Generally speaking, would you say that most people can be trusted or that you need to be very careful in dealing with people?" Further, control of corruption data has been extracted from the outlet of Worldwide Governance Indicators (WGI), which is a project of the World Bank (Kaufmann et al., 2008; World Bank, 2004; 2007). The WGI data is based on 31 diverse sources provided by 25 different organizations and, therefore, it characterizes the broader scope of diverse stakeholders. In the analysis all the scores range within a negative score of 2.5 (low control) and a positive score of 2.5 (high control), where higher scores indicate a better outcome of the corresponding institution. In the study, control of corruption apprehends the degree to which a public authority is being utilized for gaining private advantage as well as creating conditions for privileged and private interests (Alvarez and Urbano, 2011).

\section{Individual-level Independent Variable Social Capital}

The data for social capital and international entrepreneurial entry was estimated at the individual level using data from the Global Entrepreneurship Monitor (GEM) adult population survey (APS) database and the countries were chosen accordingly; additionally, a cross-sectional panel dataset was used in the study. In the GEM adult population survey each participating country interviews a randomly selected sample of people aged 18 to 64 . GEM asks entrepreneurs the following question to assess social capital: "Do you know anyone personally who has established a business in the last two years?" (Global Entrepreneurship Research, 2013). During the period of 2002-2013 entrepreneurs in our sample of 482,257 indicated the presence of experienced individuals they know personally from 44 different countries.

\section{Control Variables}

The study included a range of control variables at both the individual and country levels, which have previously been identified as the major antecedents for performing multi-level research in in the setting of institutions and behaviour (Boudreaux et al., 2019; Raza et al., 2018; Schott and Sedaghat, 2014). Individual-level control variables included age, gender, education and household income, which have been utilized extensively in cross-country entrepreneurship studies (Estrin et al., 2013; Lloyd-Reason and Mughan, 2002; Van Stel et $a l .$, 2007). Entrepreneur's age was used as a continuous variable from 18 to 64 years old; 
next, the variable gender was used as a dichotomous variable representing $1=$ male and $0=$ female; education was controlled as a five-step categorical scale with none $=0$, some secondary $=1$, secondary $=2$, post-secondary $=3$, and graduate experience $=4$; finally, household income was divided into three categories: low average $=1$, average $=2$, above average $=3$. Taking into account the literature on the country's economic development level and several indices of entrepreneurial behaviour (Boudreaux et al., 2019), we used GDP per capita, GDP growth, population and population growth from the World Bank data collection as our control variables at the country level.

\section{RESULTS}

Here we keep in view the aim of the present study, which is to develop a better understanding of the informal institutional factors corruption, taken from World Governance Indicators (WGI), and trust, taken from the World Value Survey (WVS), at the country level, influencing the relationship between entrepreneurial ventures' social capital and their ability to reach the foreign market. Table 1 depicts a summary of sample descriptives of the study. Tables $2 a$ and $2 b$ further depict the matrix of correlation for the predictors at the individual level and the country level and also the controls utilized in the study. And finally, Table 3 shows the regression results from our research.

Table 3 depicts the random effect logistic regression models for new ventures' foreign entrepreneurial entry. In order to examine our hypothesis, a three-step strategy was adopted. In order to assess the fraction of explained variance, we first included all control variables present at both the individual and country levels. All of the predictors were introduced in the next phase so that their influence on international entrepreneurial entry could be estimated (see Table 3, Column 2). Finally, in the last step each interactional term for the institutional (country-level) dimension was included (see Table 3, Column 3 and Column 4). The interaction was carried out by multiplying the institutional indicators at the country level, i.e., trust and control of corruption respectively; two interaction terms for international entrepreneurial entry were created using individual-level social capital.

Table 3 (Column 1 and 2) shows the results of odd ratios (OR), which explain the phenomena as follows: $\mathrm{OR}>1$ depicts a positive relationship and $\mathrm{OR}<1$ depicts a negative relationship. Further, Table 3 (Column 3 and Column 4) reports the odd ratios in order to explain logistic regressions' mixed effects. People with a high level of social capital $(\mathrm{OR}>2.91)$ represent entrepreneurs who are more likely to enter the international market compared to those who possess a low level of social capital, and H1 (individual-level hypothesis) is supported, stating that social capital possessed by an entrepreneur and international entrepreneurial entry have a significant positive association.

Finally, to investigate hypothesis $\mathrm{H} 2$ and hypothesis $\mathrm{H} 3$, two cross-level moderation effects were introduced between a) social capital and trust and b) social capital and control 
of corruption (Table 3, Column 3 and Column 4). The findings depicted in Table 3 for the moderating role performed through the interaction between a) social capital and trust $(\mathrm{OR}=1.14 ; \mathrm{p}<0.02)$ and $\mathrm{b})$ social capital and control of corruption $(\mathrm{OR}=1.13 ; \mathrm{p}<0.02)$ reveal a positive and significant relationship, which provides support to our hypothesis $\mathrm{H} 2$ and hypothesis $\mathrm{H} 3$, respectively.

\section{CONCLUSION}

1. In the current study, investigation is carried out specifically emphasizing the role of trust and control of corruption in the context of social capital and international entrepreneurship. The study explains that entrepreneurs with strong social capital in a society with a better control of corruption and greater level of trust will be associated with a higher level of international entrepreneurial entry. Generally, it is argued that, along with the transaction costs and various other unproductive consequences of corruption, a low level of trust in the corrupt environment limits the scale and scope of economic activity (Wintrobe, 1995) and therefore leads to a reduction in the incentives for the entrepreneur to pursue international activity (i.e., international entrepreneurial entry).

2. Within the institutional context, policy-makers have mainly concentrated their attention on studying formal institutional factors, which are not sufficient to analyze international entrepreneurial activity (Stephan and Uhlaner, 2010); there is a need to study the other side of institutional environmental factors, which are defined as informal institutions. Therefore, the findings of our study have implications for policy-makers concerned with supporting early international entrepreneurial entry by exerting influence on informal institutions. Typically, these informal institutions are subjected to change slowly over a period of time (Estrin et al., 2012) and, due to their rigidity and strong embeddedness, are difficult to alter as well. International entrepreneurial entry, as a key factor of economic growth (e.g., Schumpeter, 1934), requires policies that can remedy the missing norms hampering various entrepreneurial outcomes. Many governments are establishing various plans that are aimed at encouraging early international entrepreneurial entry, e.g., the National Science Foundation in the USA, by encouraging young entrepreneurs to carry out feasible business ventures.

3. The present study has focused attention on describing the trend of international entrepreneurial entry across various countries using data from GEM, but in the future, a study could be conducted to examine the phenomenon of home and host country or the developing and developed country context, since the level of trust, control of corruption and various other informal institutional factors may also fluctuate with a country's level of economic development. Further, entering the foreign market entails a complete set of processes that are divided into the early stage or introduction phase, the growth phase, and the breakout phase (Gabrielsson et al., 2008); therefore, future research could focus on studying the informal 
institutional context to observe whether international entrepreneurial entry is affected differently.

4. Finally, the study opens an avenue to examine effects of the informal institutional context on the international entrepreneurial entry of new ventures. The formal institutional context has already received a lot of attention from scholars, but the informal institutional context has been studied less so far and, specifically, empirical evidence is quite scarce (Muralidharan and Pathak, 2017). The study contributes to stating the positive effects of informal institutions on international entrepreneurial entry within the context of social capital possessed by entrepreneurs.

Table 2a

\section{Correlation matrix - individual-level correlations}

\begin{tabular}{lrrrrrr}
\hline & \multicolumn{1}{c}{} & $\mathbf{2}$ & $\mathbf{3}$ & $\mathbf{4}$ & $\mathbf{5}$ & $\mathbf{6}$ \\
\hline International entry & 1 & & & & & \\
\hline Age & -0.042 & 1 & & & & \\
\hline Gender & -0.040 & 0.012 & 1 & & & \\
\hline Income & 0.057 & -0.020 & -0.093 & 1 & & \\
\hline Education & 0.057 & -0.134 & -0.022 & 0.218 & 1 & \\
\hline Social capital & 0.114 & -0.123 & -0.097 & 0.109 & 0.083 & 1 \\
\hline
\end{tabular}

Table $2 b$

Correlation matrix - country-level correlations

\begin{tabular}{lrrrrrrr}
\hline & \multicolumn{1}{c}{$\mathbf{1}$} & \multicolumn{1}{c}{$\mathbf{2}$} & $\mathbf{3}$ & $\mathbf{4}$ & $\mathbf{5}$ & $\mathbf{6}$ & $\mathbf{7}$ \\
\hline International entry & 1 & & & & & & \\
\hline GDP & -0.015 & 1 & & & & & \\
\hline GDP growth & -0.013 & 0.947 & 1 & & & & \\
\hline Population & -0.014 & -0.265 & -0.231 & 1 & & \\
\hline Population growth & -0.043 & -0.313 & -0.242 & 0.670 & 1 & \\
\hline Trust & -0.018 & 0.554 & 0.601 & 0.275 & -0.019 & 1 \\
\hline Corruption & -0.001 & 0.815 & 0.837 & -0.302 & -0.295 & 0.487 & 1 \\
\hline
\end{tabular}




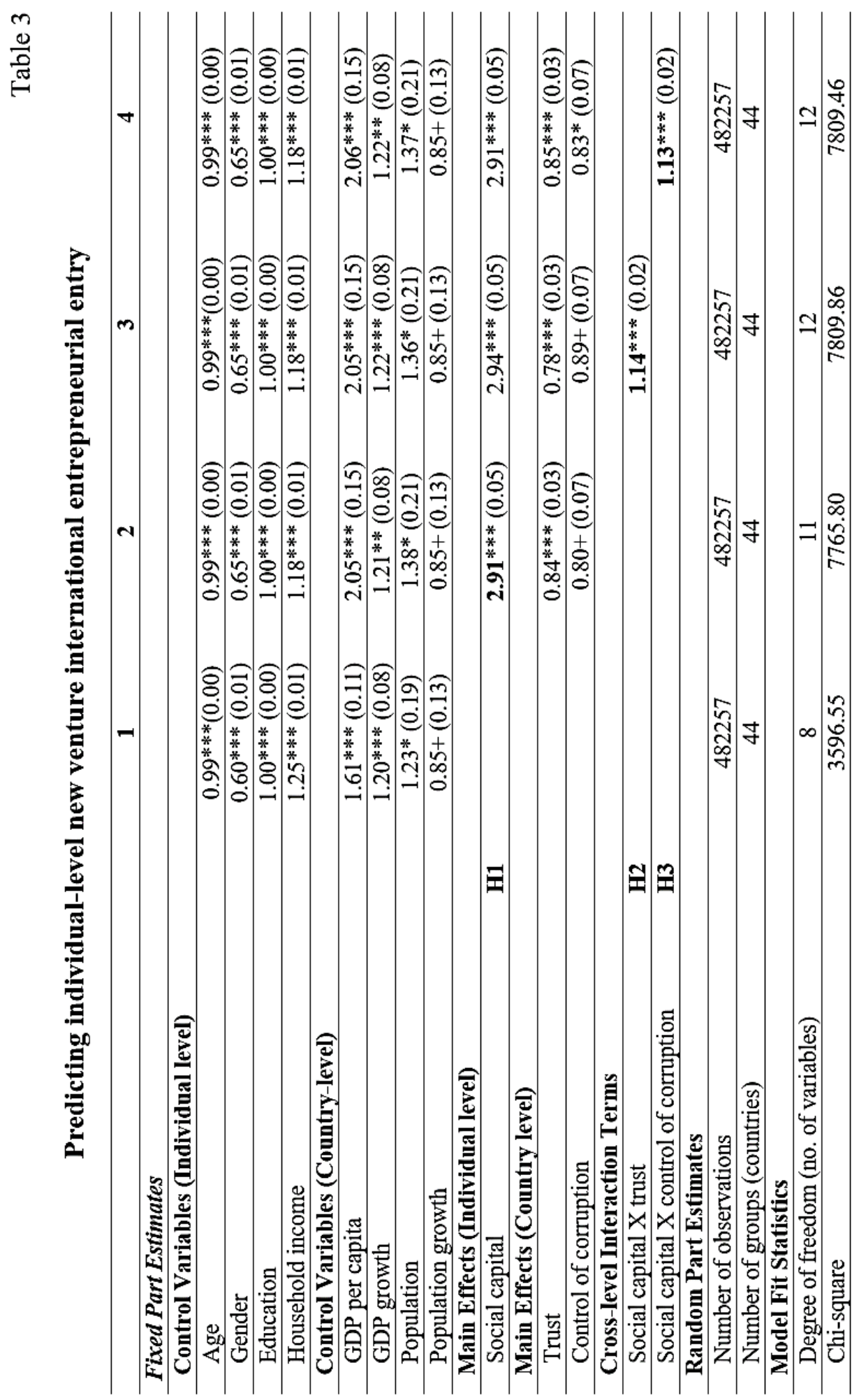




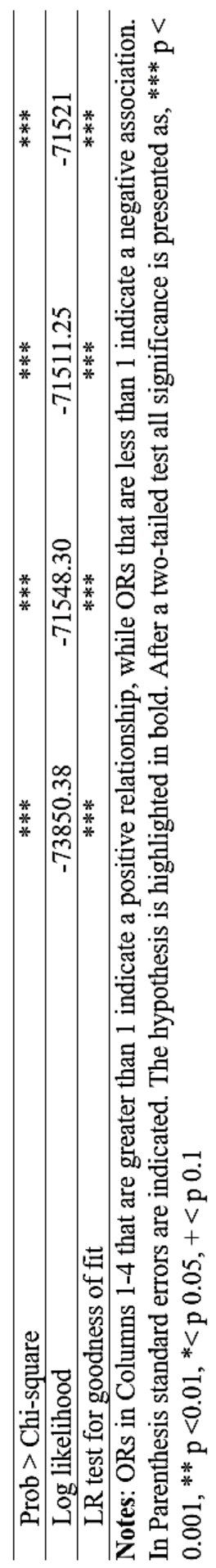




\section{REFERENCES}

1. Alvarez, C., Urbano, D. (2011), "Environmental factors and entrepreneurial activity in Latin America”, Acad. Rev. Latinoam. Ad., Vol. 48, pp. 31-45.

2. Anand, J., Delios, A. (1997), "Location specificity and the transferability of downstream assets to foreign subsidiaries", Journal of International Business Studies, Vol. 28, pp. 579603.

3. Anderson, A., Park, J. and Jack, S. (2007), "Entrepreneurial social capital”, International Small Business Journal, Vol. 25, No. 3, pp. 245-272.

4. Anokhin, S., Schulze, W. S. (2009), "Entrepreneurship, innovation, and corruption”, Journal of Business Venturing, Vol. 24, No. 5, pp. 465-476.

5. Aparicio, S., Urbano, D. and Audretsch, D. (2016), "Institutional factors, opportunity entrepreneurship and economic growth: Panel data evidence", Technological Forecasting and Social Change, Vol. 102, pp. 45-61.

6. Axelrod, R. (1986), “An evolutionary approach to norms”, American Political Science Review, Vol. 80, No. 4, pp. 1095-1111.

7. Baumol, W. J. (1990), "Entrepreneurship: Productive, unproductive, and destructive", The Journal of Political Economy, Vol. 98, No. 5, pp. 893-921.

8. Beckinsale, M., Ram, M. and Theodorakopoulos, N. (2011), "ICT adoption and e-business development”, International Small Business Journal, Vol. 29, pp. 193-219.

9. Bjørnskov, C. (2003), "Corruption and social capital”, working paper, Aarhus School of Business.

10. Bonaccorsi, A. (1992), "On the relationship between firm size and export intensity", Journal of International Business Studies, Vol. 23, pp. 605-635.

11. Bosma, N. (2013), “The Global Entrepreneurship Monitor (GEM) and its impact on entrepreneurship research", Foundations and Trends ${ }^{\circledR}$ in Entrepreneurship, Vol. 9, No. 2, pp. 143-248

12. Boudreaux, C. J., Nikolaev, B. N. and Klein, P. (2019), "Socio-cognitive traits and entrepreneurship: The moderating role of economic institutions", Journal of Business Venturing, Vol. 34, No. 1, pp. 178-196.

13. Bowen, H. P., De Clercq, D. (2008), "Institutional context and the allocation of entrepreneurial effort”, Journal of International Business Studies, Vol. 39, No. 4, pp. 747767. 
14. Chang, S. J., Rosenzweig, P. M. (2001), "The choice of entry mode in sequential foreign direct investment”, Strategic Management Journal, Vol. 22, pp. 747-76.

15. Chen, J., Saarenketo, S. and Puumalainen, K. (2018), "Home country institutions, social value orientation, and the internationalization of ventures", International Business Review, Vol. 27, No. 2, pp. 443-454.

16. Chetty, S., Agndal, H. (2007), "Social capital and its influence on changes in internationalization mode among small and medium-sized enterprises", Journal of International Marketing, Vol. 15, No. 1, pp. 1-29.

17. Cheung, G. C. K. (2004), "Chinese diaspora as a virtual nation: interactive roles between economic and social capital”, Political Studies, Vol. 52, pp. 664-684.

18. Davies, M. A. P., Lassar, W., Manolis, C. et al. (2011), “A model of trust and compliance in franchise relationships", Journal of Business Venturing, Vol. 26, No. 3, pp. 321-340.

19. Doucouliagos, H., Ulubasoglu, M. (2008), "Democracy and economic growth: a metaanalysis", American Journal of Political Science, Vol. 52, No. 1, pp. 61-83.

20. Douhan, R., Henrekson, M. (2010), "Entrepreneurship and second-best institutions: Going beyond Baumol's typology”, J. Evol. Econ., Vol. 20, pp. 629-643.

21. Elam, A., Terjesen, S. (2010), "Gendered institutions and cross-national patterns of business creation for men and women", The European Journal of Development Research, Vol. 22, No. 3, pp. 331-348.

22. Erramilli, M. K., Rao, C. P. (1993), “Service firms' international entry-mode choice: a modified transaction-cost analysis approach", Journal of Marketing, Vol. 57, pp. 19-38.

23. Escandon-Barbosa, D., Urbano-Pulido, D. and Hurtado-Ayala, A. (2019), "Exploring the relationship between formal and informal institutions, social capital, and entrepreneurial activity in developing and developed countries", Sustainability, Vol. 11, No. 2, pp. 550.

24. Estrin, S., Korosteleva, J. and Mickiewicz, T. (2012), "Which institutions encourage entrepreneurial growth aspirations?", Journal of Business Venturing, Vol. 28, No. 4, pp. $564-580$.

25. Estrin, S., Mickiewicz, T. and Stephan, U. (2013), "Entrepreneurship, social capital, and institutions: Social and commercial entrepreneurship across nations", Entrepreneurship Theory and Practice, Vol. 37, No. 3, pp. 479-504.

26. Fink, M., Kessler, A. (2010), “Cooperation, trust and performance: empirical results from three countries”, British Journal of Management, Vol. 21, No. 2, pp. 469-483. 
27. Freixanet, J., Renart, G. (2020), “A capabilities perspective on the joint effects of internationalization time, speed, geographic scope and managers' competencies on SME survival", Journal of World Business, Vol. 55, No. 6, pp. 101-110.

28. Gabrielsson, M., Kirpalani, V. H., Dimitratos, P., Solberg, C. A. and Zucchella, A. (2008), "Born globals: Propositions to help advance the theory", International Business Review, Vol. 17, No. 4, pp. 385-401.

29. Global Entrepreneurship Research Association (2013), Global Entrepreneurship Monitor, available at: http://www.gemconsortium.org.

30. Gorsira, M., Denkers, A. and Huisman, W. (2018), "Both sides of the coin: Motives for corruption among public officials and business employees", Journal of Business Ethics, Vol. 151, No. 1, pp. 179-194.

31. Granovetter, M. (1973), "The strength of weak ties", American Journal of Sociology, Vol. 78, No. 6, pp. 1360-1380.

32. Hitt, M. A., Ireland, R. D., Camp, S. M. and Sexton, D. L. (2001), "Strategic entrepreneurship: Entrepreneurial strategies for wealth creation", Strategic Management Journal, Vol. 22, pp. 479-491.

33. Hohmann, H.-H., Welter, F. (2005), Trust and Entrepreneurship: A West-East Perspective, Edward Elgar, Cheltenham.

34. Inouye, T. M., Joshi, A. M., Hemmatian, I. and Robinson, J. A. (2020), “Counteracting Globalization's Skeptics: How Diasporas Influence the Internationalization Preferences of Minority Entrepreneurs' Firms", Global Strategy Journal, Vol. 10, No. 1, pp. 123-173.

35. Jack, S. L., Anderson, A. R. (2002), "The effects of embeddedness on the entrepreneurial process", Journal of Business Venturing, Vol. 17, pp. 467-487.

36. Jiang, X., Liu, H., Fey, C. and Jiang, F. (2018), “Entrepreneurial orientation, network resource acquisition, and firm performance: A network approach", Journal of Business Research, Vol. 87, pp. 46-57.

37. Johanson, J., Vahlne, J.-E. (2006), "Commitment and opportunity development in the internationalization process model”, Manag. Int. Rev., Vol. 46, No. 2, pp. 165-178.

38. Jones, O., Conway, S. (2004), "The international reach of entrepreneurial social networks: The case of James Dyson in the UK", in International Entrepreneurship in Small and Medium Size Enterprises, Edward Elgar, Cheltenham, pp. 87-106.

39. Kaufmann, D., Kraay, A. and Mastruzzi, M. (2008), “Governance matters VII: Aggregate and individual governance indicators 1996-2007”, working paper, WPS 4654, World Bank Policy Research. 
40. Kay, F. M., Hagan, J. (2003), "Building trust: Social capital, distributive justice, and loyalty to the firm", Law and Social Inquiry, Vol. 28, No. 2, pp. 483-519.

41. Kim, P. H., Aldrich, H. E. (2005), Social Capital and Entrepreneurship, Now Publishers, Hanover, MA.

42. Ledeneva, A. V. (1998), Russia's Economy of Favours: Blat, Networking and Informal Exchange, Cambridge University Press, Cambridge.

43. Lloyd-Reason, L., Mughan, T. (2002), "Strategies for internationalisation within SMEs: the key role of the owner-manager", Journal of Small Business and Enterprise Development, Vol. 9, No. 2, pp. 120-129.

44. Luo, Y. (2001), "Determinants of entry in an emerging economy: a multilevel approach", Journal of Management Studies, Vol. 38, pp. 443-72.

45. Lockett, N., Kerr, R. and Robinson, S. (2008), "Multiple perspectives on the challenges for knowledge transfer between higher education institutions and industry", International Small Business Journal, Vol. 26, No. 6, pp. 661-681.

46. Maxwell, A. L., Levesque, M. (2011), “Trustworthiness: A critical ingredient for entrepreneurs seeking investors", Entrepreneurship Theory and Practice, Epub ahead of print, 3 July 2011, DOI: 10.1111/j.1540-6520.2011.00475.x.

47. McDougall, P. P., Oviatt, B. M. (2000), "International entrepreneurship: The intersection of two research paths", Academy of Management Journal, Vol. 43, pp. 902-908.

48. McKeever, E., Anderson, A. and Jack, S. (2014), "Entrepreneurship and mutuality: social capital in processes and practices", Entrepreneurship and Regional Development, Vol. 26, Nos. 5-6, pp. 453-477.

49. McMullen, J. S., Bagby, D. R. and Palich, L. E. (2008), "Economic freedom and the motivation to engage in entrepreneurial action", Entrepreneurship Theory and Practice, Vol. 32, No. 5, pp. 875-895.

50. Méon, P. G., Sekkat, K. (2005), "Does corruption grease or sand the wheels of growth?”, Public Choice, Vol. 122, Nos. 1-2, pp. 69-97.

51. Muralidharan, E., Pathak, S. (2017), "Informal institutions and international entrepreneurship”, International Business Review, Vol. 26, pp. 288-302.

52. Nahapiet, J., Ghoshal, S. (1998), "Social capital, intellectual capital and the organizational advantage", Academy of Management Review, Vol. 23, pp. 242-266.

53. North, D. C. (1990), Institutions, Institutional Change and Economic Performance, Cambridge University Press, Cambridge. 
54. Oviatt, B. M., McDougall, P. P. (1994), "Toward a theory of international new ventures", Journal of International Business Studies, Vol. 25, No. 1, pp. 45-64.

55. Oviatt, B. M., McDougall, P. P. (2005), "The internationalization of entrepreneurship", Journal of International Business Studies, Vol. 36, No. 1, pp. 2-8.

56. Paldam, M., Svendsen, G. T. (2002), "Missing Social Capital and the Transition in Eastern Europe”, Journal for Institutional Innovation, Development and Transition, Vol. 5, pp. 2134.

57. Paxton, P. (1999), "Is social capital declining in the United States? A multiple indicator assessment”, American Journal of Sociology, Vol. 105, No. 1, pp. 88-127.

58. Peiris, I. K., Akoorie, M. E. and Sinha, P. (2012), "International entrepreneurship: A critical analysis of studies in the past two decades and future directions for research", Journal of International Entrepreneurship, Vol. 10, No. 4, pp. 279-324.

59. Puthusserry, P., Child, J. and Khan, Z. (2020), "Social capital development through the stages of internationalization: Relations between British and Indian SMEs", Global Strategy Journal, Vol. 10, No. 2, pp. 282-308.

60. Raza, A., Muffatto, M. and Saeed, S. (2018), "Cross-country differences in innovative entrepreneurial activity”, Management Decision, Vol. 58, No. 7, pp. 1301-1329.

61. Reynolds, P. D., Bosma, N., Autio, E., Hunt, S., De Bono, N. et al. (2005), “Global entrepreneurship monitor: data collection design and implementation 1998-2003”, Small Bus. Econ., Vol. 24, No. 3, pp. 205-231.

62. Rodrigues, S. B., Child, J. (2012), "Building social capital for internationalisation", RAC, Rio de Janeiro, Vol. 16, No. 1, pp. 23-38.

63. Schott, T., Sedaghat, M. (2014), 'Innovation embedded in entrepreneurs' networks and national educational systems”, Small Business Economics, Vol. 43, pp. 463-476.

64. Schumpeter, J. A. (1934), The Theory of Economic Development, Harvard University Press, Cambridge, MA.

65. Scott, W. R. (1995), Institutions and Organizations, Sage Publications, Thousand Oaks, CA.

66. Sedziniauskiene, R., Sekliuckiene, J. and Zucchella, A. (2019), "Networks' impact on the entrepreneurial internationalization: A literature review and research agenda", Management International Review, Vol. 59, No. 5, pp. 779-823.

67. Şengun, A. E., Nazli Wasti, S. (2009), "Revisiting trust and control”, International Small Business Journal, Vol. 27, No. 1, pp. 39-69. 
68. Shahid, M. U. (2020), "Institutional governance matters in the context of social capital and international entrepreneurial entry: A multi-level perspective", Journal of Business Management, Vol. 18, pp. 94-116.

69. Siddiqui, K. (2019), "Corruption and Economic Mismanagement in Developing Countries", The World Financial Review, Vol. 1, No. 1, available at: https://www.researchgate.net/profile/Kalim_Siddiqui/publication/331199370_Corruption_ and_Economic_Mismanagement_in_Developing_Countries/links/5c6be0f1299bf1e3a5b29 f0c/Corruption-and-Economic-Mismanagement-in-Developing-Countries.pdf.

70. Smallbone, D., Welter, F. (2001), "The distinctiveness of entrepreneurship in transition economies”, Small Business Economics, Vol. 16, No. 4, pp. 249-262.

71. Stephan, U., Uhlaner, L. M. (2010), "Performance-based vs. socially supportive culture: A cross-national study of descriptive norms and entrepreneurship", Journal of International Business Studies, Vol. 41, No. 8, pp. 1347-1364.

72. Stratling, R., Wijbenga, F. H. and Dietz, G. (2011), "The impact of contracts on trust in entrepreneur-venture capitalist relationships", International Small Business Journal. Epub ahead of print, 18 February 2011, DOI: 10.1177/0266242610388822.

73. Szyliowicz, D., Galvin, T. (2010), “Applying broader strokes: Extending institutional perspectives and agendas for international entrepreneurship research?”, International Business Review, Vol. 19, No. 4, pp. 317-332.

74. Tantardini, M., Garcia-Zamor, J. C. (2015), “Organizational social capital and anticorruption policies: An exploratory analysis”, Public Organization Review, Vol. 15, No. 4, pp. 599-609.

75. Tihanyi, L., Griffith, D. A. and Russell, C. J. (2005), "The effect of cultural distance on entry mode choice, international diversification, and MNE performance: a meta-analysis", Journal of International Business Studies, Vol. 36, pp. 1-14.

76. Uslaner, E. M. (2001), “Trust and Corruption”, Paper presented at the Conference on Political Scandals, Past and Present at the University of Salford, 21-23 June.

77. Van Stel, A., Storey, D. J. and Thurik, A. R. (2007), "The effect of business regulations on nascent and young business entrepreneurship", Small Business Economics, Vol. 28, Nos. 23, pp. 171-186.

78. Vida, I. (2000), “An empirical inquiry into international expansion of US retailers”, International Marketing Review, Vol. 17, pp. 454-475.

79. Welch, L. S. (2004), "International entrepreneurship and internationalization: Common threads", in Dana, L.-P. (Ed.), Handbook of Research on International Entrepreneurship, Edward Elgar, Cheltenham, UK. 
80. Welter, F., Smallbone, D. (2003), "Entrepreneurship and enterprise strategies in transition economies: An institutional perspective", in Small Firms and Economic Development in Developed and Transition Economies: A Reader, pp. 95-114.

81. Welter, F., Smallbone, D. (2006), "Exploring the role of trust in entrepreneurial activity", Entrepreneurship: Theory and Practice, Vol. 30, pp. 465-475.

82. Wennekers, S., Van Stel, A., Thurik, R. and Reynolds, P. (2005), "Nascent entrepreneurship and the level of economic development", Small Bus. Econ., Vol. 24, No. 3, pp. 293-309.

83. Wintrobe, R. (1995), "Some economics of ethnic capital formation and conflict", in Breton, A., Galeotti, G., Salmo, P. and Wintrobe, R. (Eds.), Nationalism and Rationality, Cambridge University Press, Cambridge, pp. 43-70.

84. World Bank (2004), "Doing Business in 2004: Understanding Regulations", IBRD/World Bank, Washington, D.C., available at: https://elibrary.worldbank.org/doi/abs/10.1596/08213-5341-1.

85. World Bank (2007), "Doing Business in 2007: How to Reform”, IBRD/World Bank, Washington, D.C., available at: http://www.doingbusiness.org/documents/DoingBusiness2007_Overview.pdf.

86. Yan, Y., Guan, J. (2018), "Social capital, exploitative and exploratory innovations: The mediating roles of ego-network dynamics", Technological Forecasting and Social Change, Vol. 126, pp. 244-258.

87. Yeung, H. W. C. (2002), "Entrepreneurship in international business: An institutional perspective?”, Asia Pacific Journal of Management, Vol. 19, No. 1, pp. 29-61.

88. Yli-Renko, H., Autio, E. and Tontti, V. (2002), "Social capital, knowledge, and the international growth of technology-based new firms", International Business Review, Vol. 11, No. 3, pp. 279-304. 
Received: 14 April 2020

Accepted for publishing: 6 January 2021

DOI: 10.32025/JBM19003

\title{
The challenges of cybersecurity insurance development: The case of Latvia
}

\author{
TATJANA VOLKOVA \\ LINDA JEKABSONE \\ ZITA LAVRINOVICA \\ ELINA SABA \\ MARIS SABA
}

\section{ABSTRACT}

Purpose. This paper aims to provide an overview of the current challenges of cybersecurity insurance, focusing on the identification of development constraints and opportunities and the key impact factors of this recently emerging insurance market in Latvia.

Methodology. The authors used theoretical and empirical research methods, e.g., a literature review, surveys of experts from principal insurance companies and professionals from prominent mobile network operators, and interviews with experts in cybersecurity and pioneers of cybersecurity insurance in Latvia.

Findings. The research results illustrate the immense difficulties in providing cyber risk insurance in Latvia. The lack of historical knowledge and evolving nature of cyber risks create significant challenges in quantifying and expressing cyber threats in monetary value. Cyber risk modelling is in its infancy, as events and threat vectors are still evolving. Due to the evolving nature of cyber risks, simulating events and fitting into traditional risk management forms are the primary challenges for insurance companies. Despite the increasing relevance of cyber risks to businesses, research on guidelines and methods of mitigating cyber risks with cyber insurance is still limited.

Social implications. Cyber insurance is a direct result of public awareness of cyber threats and preparedness to mitigate business risks. Thus, cyber insurance is an integral part of educating and building a more resilient society. 
Originality/Value. The authors propose various approaches to cybersecurity insurance development, such as technology awareness building, standardization of mandatory reporting requirements and public-private partnerships in which the government covers part of the risk to overcome insurability limitations.

Keywords: cyber insurance, cybersecurity, cyber insurance market, cyber risks

\section{INTRODUCTION}

With the increasing importance of information technology (IT) in the business and public sectors, there has been a growing impact of cybersecurity threats, i.e., their effect on these sectors' processes. One of the ways to mitigate cybersecurity risks is cybersecurity insurance.

There is no common understanding regarding the essence of cybersecurity insurance. According to Matthew, cybersecurity insurance is an insurance product which is used in protecting businesses as well as individual users from information technology-based risks (Matthew, 2019). Sometimes referred to as cyber liability or cyber risk insurance, its definition has evolved considerably due to new emerging cyber threats. Initially there was a focus on media and software risks, especially banking, and this expanded to network security, unauthorized access, data loss and other virus-related issue coverages (Matthew, 2019). Later cybersecurity insurance also included first-party (relates to loss directly suffered by the insured) and third-party (relates to claims brought by parties external to the contract) coverages, still excluding regulatory claims and fines and penalties (Romanovsky et al., 2019). With the expansion of the Internet of things, cybersecurity insurance includes further contemporary items and issues. Even with the negative worldwide influence of COVID-19 on economic development, the global cybersecurity insurance market forecast is estimated to grow at a CAGR of $21.2 \%$ from USD 7.8 billion in 2020 to USD 20.4 billion in 2025 (Research and Markets, 2020).

Latvia as a research object in this relationship between growing IT business, cybersecurity risks and cybersecurity insurance is particularly appealing. Firstly, Latvia is still in the process of integrating into the market economy regarding new services and products that have been around in the Western world for a considerable time. Secondly, information and communication technologies play an important and especially growing role in the Latvian economy - in the last quarter of 2019, this sector shared $5.16 \%$ of the whole economy (Central Statistics Bureau, 2020). These results exclude other sectors that are highly dependent on IT: energy, banking, manufacturing, logistics and others. This paper aims to provide an overview of the current situation of cybersecurity insurance, identifying challenges in this recently emerging insurance market in Latvia.

This paper consists of four parts. The authors will start with analysing theoretical literature regarding the costs of cyber threats and cybersecurity insurance. Further on, the research 
design and methodology will explain how observance of cybersecurity insurance in Latvia was conducted, and this will be followed by presentation and analysis of the research results. Finally, concluding remarks will close this study.

\section{LITERATURE REVIEW}

Cybersecurity insurance is still an evolving subject of research and, therefore, is experiencing harsh debates regarding its definition. Besides the previously mentioned perspective from Matthew, Romanovsky, Ablon, Kuhn and Jones state that "cyber insurance addresses first and third-party losses as a result of a computer-based attack or malfunction of a firm's information technology systems" (Romanovsky et al., 2019). These two definitions show the gaps in comprehension of cybersecurity insurance, for example, what exact risks are included and excluded and whether private customers can attain such insurance coverage. In addition to these researchers (Romanovsky, Anderson, Matthew and others), major contributors to the research field include private think tanks such as FICO and public entities such as governments (the UK is an outstanding example of interconnectivity between insurance brokers and the government) and international organizations (the EU, OECD and others).

Regardless of the definition, an integral part of cybersecurity insurance is estimating the cost of cybercrime - it has to be damaging enough for anyone to be willing to give up part of their income to mitigate the risk. The European Commission's 2007 Communication "Towards a general policy on the fight against cybercrime" has proposed a threefold definition for the cost of cybercrime:

1. Traditional forms of crime such as fraud or forgery, though committed over electronic communication networks and information systems (direct losses)

2. The publication of illegal content over electronic media (cost to society)

3. Crimes unique to electronic networks such as attacks against information systems, denial of service and hacking (defence costs) (OECD, 2017)

Anderson and others have worked on research to investigate the nature and size of the topranking cybercrime costs of today, especially since 2012, when the last such report was made (Anderson et al., 2019). The following figures give an impression of how valuable the cybercrime industry is and how appealing it makes cybersecurity insurance as a risk effect mitigation tool (see Table 1). 
Cybercrime types and the value of damage, million, billion $£$ and USD (2012-2018)

\begin{tabular}{cc}
\hline Crime Type & Value of Damage \\
\hline Online credit card fraud & $£ 731.8$ million (UK) \\
\hline Online bank fraud & $£ 121.4$ million (UK) \\
\hline Authorized push payments & $£ 236$ million (UK) \\
\hline In-person card fraud & $£ 158$ million (UK) \\
Ransomware & Over $\$ 10$ million (US) \\
\hline Cryptocrime & $\$ 2$ billion (US) \\
\hline Ad fraud & $\$ 1-9$ billion (US) \\
\hline Pharmaceuticals & Tens of millions of $\$($ US) \\
\hline Coupon fraud & $\$ 300 \mathrm{~m}+($ US) \\
\hline Loyalty-programme fraud & $\$ 235$ million (US) \\
\hline Travel fraud & $\$ 1$ billion (US) \\
\hline Counterfeit software & $\$ 1-9$ million (US) \\
\hline Copyright theft & $\$ 10$ million (US) \\
\hline Fake antivirus & $\$ 7.1$ million (US) \\
\hline Tech support scams & $\$ 39$ million (US) \\
\hline Compromised email & Regulatory and legal costs \\
\hline Fake companies & Tens of millions of $\$($ US) \\
\hline Advance fee fraud & $\$ 100$ million (US) \\
\hline Business email compromise & $\$ 1.3$ billion (US) \\
\hline Telecoms fraud & $\$ 7$ billion (US) \\
\hline Wanacry/NotPetya & $\$ 1-2$ billion (US) \\
\hline Fiscal fraud & $\$ 1-9$ billion (US) \\
\hline Romance scams & $\$ 143$ million (US) \\
\hline
\end{tabular}

Source: Anderson et al., 2019

Determining cybersecurity crime type and value of damage is only part of implementing cybersecurity insurance as a means to mitigate information technology-related risks. Cybersecurity insurance, just like any other insurance business, has to be economically viable. In order to accomplish this, according to Insurance Europe, certain principles of insurability have to be met: risks must occur randomly, risks must be quantifiable, and a sufficiently large community with assets at risk can be established to share the risk (OECD, 2017). When these criteria are achieved, the creation of an insurance policy can happen - an interaction between demand, supply and cyberspace-related factors.

The OECD points out two factors that have the greatest effect on cybersecurity insurance policy price: first, the difficulty in quantifying a relatively new and evolving risk; second, the potential for significant correlation across insureds, also known as an accumulation risk (OECD, 2017). According to the CRO Forum, quantifiability of cyber risk as a shortfall for the cybersecurity insurance business is mostly due to limited availability of historic data, the changing nature of cyber risk and the lack of transparency about security practices and 
past incidents in the corporate world (OECD, 2017). The organization points out that in the case of a cyber risk, there is a huge potential for losses to be correlated across insureds and across various types of coverages provided to a single insured (OECD, 2017).

Accumulation risk is therefore due to high levels of interconnectivity - common software vulnerability, information technology service disruptions and critical infrastructure damage.

From potential customers' perspective, according to the OECD, willingness to demand and pay for cybersecurity insurance as a product is most likely affected by a lack of awareness of potential losses from cyber risk, misunderstandings about the need for coverage as well as a potential mismatch between what companies are seeking and the coverage offered $77 \%$ of companies interviewed in the UK in 2016 stated that coverage only partially met their needs, indicating reputational damage and intellectual property theft as the most concerning risks they would like to be covered (OECD, 2017).

Despite the limiting and developing factors of the cybersecurity insurance market, it doubled in the time period between 2015 and 2018, reaching an estimated \$4 billion in premiums (Anderson et al., 2019). In a similar 2018 report by NetDiligence, the conclusion was that one third of pay-outs are for legal costs such as defence lawyers and settlements; this information has to be considered when calculating total cybersecurity insurance costs (NetDiligence, 2018). An important role in the development of cybersecurity insurance is played by data providers that offer risk assessment to organizations seeking insurance and underwriters, such as Bitsight, Security Scorecard and QuadMetrics (Anderson et al., 2019).

When looking at the Western European market for cybersecurity insurance, the trend is similar. According to a FICO 2017 survey covering 11 countries (from Europe - the UK, Norway, Sweden, Finland and Germany) and 500 companies, the UK leads with $90 \%$ of companies having cybersecurity insurance and $37 \%$ covering the most likely cybersecurity risks (FICO, 2018). The Nordic countries are not far behind with $76 \%$ of Finnish companies, $72 \%$ of Norwegian companies and $57 \%$ of Swedish companies being cybersecurity insured (FICO, 2018). This survey also reflects Nordic cyberspace's profile $-65 \%$ of organizations expected an increase in cyber risks, $41 \%$ of organizations experienced an increase in attempted cyber breaches, more than half of organizations were expecting a budget increase for their cybersecurity, $34 \%$ of organizations have privacy regulations as the biggest influencing factor in cybersecurity strategy (32\% - pressure from customers and investors, 20\% - an increase in cyberattacks) and $80 \%$ of organizations expect the cybersecurity risk to come from their own ranks, not third-party vendors (FICO, 2018). When analyzing cybersecurity insurance trends across Europe, it is essential to observe the UK. According to a report compiled by the British government in conjunction with Marsh in 2015, the cabinet helped the insurance industry to establish cybersecurity insurance as part of organizations' cybersecurity toolkit by developing a guide on cybersecurity insurance and organizing a data, threat and trend-pooling public forum without revealing anyone's identity (Marsh, 2015). The British example shows that 
governmental support is essential in the early developmental stages of cybersecurity insurance.

\section{METHODOLOGY}

The main goal of the research is to provide an overview of the current challenges of cybersecurity insurance, focusing on the identification of development constraints and opportunities and the key impact factors of this recently emerging insurance market in Latvia. The research combined qualitative and quantitative methods for exploring and understanding the defined problem statement. In the framework of this research the authors conducted a semi-structured interview with a representative from the Latvian cybersecurity industry and a survey of Latvian insurance companies and Latvian mobile operators in order to understand why cybersecurity insurance is not widely offered on the Latvian market.

\section{Survey of insurance companies}

The research team identified 10 principal non-life insurance companies in Latvia: "Balta", "Baltijas Apdrosinasanas Nams", "BTA Baltic Insurance Company”, "Compensa Vienna Insurance Group ADB Latvian branch", "ERGO Insurance SE Latvian branch”, "ADB "Gjensidige” Latvian branch", "If PandC Insurance AS Latvian branch", "Seesam Insurance AS Latvia branch", "Swedbank PandC Insurance AS Latvian branch", and "Balcia Insurance SE". 8 of them are members of the Latvian Insurers Association. The insurance companies were selected according to their expertise at the international level and current exposure in the Latvian insurance market.

Of the ten companies approached, six agreed to the survey, making the response rate $60 \%$. The representatives who answered the questions and shared their experience are managers of various levels or representatives of product development departments, such as Corporate Property Insurance Products Manager; Product Manager; Head of the Commercial Products, Pricing and Risk Underwriting Department; and Head of the Latvian Branch. All companies participating in the survey have already analyzed the inclusion of cybersecurity insurance in their product portfolio.

The authors developed a questionnaire based on the literature review, posing 8 qualitative questions. The survey was conducted in February 2020.

The authors focused on understanding the development of the cybersecurity insurance market. The core research questions were: Has the insurer seen an increase in demand for cybersecurity insurance products from companies in the last 2-3 years? What are the key impact factors influencing the cybersecurity insurance service offer? What are/would 
insurance companies consider as contributing factors to the cybersecurity insurance service offer?

\section{Interview with an expert}

The research team initiated the research with a face-to-face interview with the Chief Executive Officer (CEO) of Latvian insurance company X, which offers upto-date high-end insurance solutions, including cybersecurity insurance. At the time of the study, the number of cybersecurity insurance policies issued by Latvian insurers was not large and this segment of the business was just beginning to grow. The expert of company $\mathrm{X}$ was selected because this company had issued several cybersecurity insurance policies; accordingly, this was the company with the largest experience of where such risks are located. An interview was conducted in January 2020 in order to find out how long the company had been offering cybersecurity insurance services in Latvia, whether this was popular amongst Latvian entrepreneurs, what restrictions and limitations they were facing and what the company's vision for the future was, including forecasts for the growth in popularity of cyber insurance products. The interview was based on experience and opinion and provides a general idea plus a realistic view of the contemporary expert on current issues regarding cybersecurity insurance from different perspectives: demand, supply, hindrances, and general understanding.

\section{Surveys of Latvian mobile operators}

The research team identified all the mobile operator companies operating in Latvia over the last five-year period. The authors sent the questionnaire to the following 3 mobile operators operating in Latvia: "LMT", "BITE Latvija", and "Tele2". At the time of this research, the leader of the Latvian mobile communication market was "LMT" with a $45 \%$ market share, followed by "Tele2" with $33 \%$ of the market and "BITE Latvija" with a 22\% market share according to a Public Utilities Commission report. One representative from each company was selected according to 2 criteria: executive or mid-level management position and direct involvement in the company's cybersecurity management. A response was received from all 3 company representatives, making the response rate $100 \%$.

The mobile communication industry as a possible cybersecurity insurance buyer was chosen because their services largely depend on IT, are widely recognized, have a brand, have a large customer base, hold comprehensive customer data, and have an IT infrastructure critical to their business. All these business conditions make them an appealing target for cyberattacks. Large companies have done a lot to make themselves cyber-secure, yet some risks remain, including through their exposure from third parties, 
service providers, product suppliers or customers (Marsh, 2015). But it should be noted that not just business giants are vulnerable to destructive cyberattacks. It is the data, not the size of the company, that makes a business attractive to cyber criminals, especially data such as customer contact information, credit card data, health data, or valuable intellectual property (Armerding, 2015).

The research team developed a questionnaire about cyber insurance based on the literature review. According to Marsh Ltd. research, the potential losses from cybersecurity incidents and cyberattacks fall into the following 11 loss categories: intellectual property theft, business interruption, data and software loss, cyber extortion, cybercrime/cyber fraud, breach of privacy events, network failure liabilities, impact on reputation, physical asset damage, death and bodily injury, and incident investigation and response costs (Marsh, 2015). The questionnaire focuses on malicious attacks because of the much greater damage they can cause compared to non-malicious attacks. The research team approached mobile operators operating in Latvia with questions based on these loss categories as well as questions about their general interest in acquiring a cybersecurity insurance policy.

Asking about different loss categories shows the extent to which cyber risk deserves to be considered and that it is much greater than the current focus on data breaches, which companies these days seem to understand as the biggest threat. This categorization also recognizes that the impact of the attack may be felt well beyond the organization affected. Companies should also consider the impact a cyberattack on a supplier or other third party could have on their own business. In the questionnaire the mobile operator representatives were asked to explain whether they would be interested in insuring their company and which of the loss categories they would most likely be interested in having covered in an insurance policy. The questionnaire focused on cyberattacks and malicious IT failures, since malware and web-based attacks continue to be the most expensive according to Accenture research (Accenture, 2019). The survey was conducted in February 2020.

\section{RESULTS AND DISCUSSION}

\section{Results of the interviews with insurance companies}

The research results illustrate the immense difficulties and significant challenges in providing cybersecurity insurance. The importance of cybersecurity, at both the corporate and national level, is only growing (Ministry of Defence of the Republic of Latvia, 2019). Cyber risks are not avoidable, but they must be manageable; therefore, the authors emphasize the need to continue working on this topic. The National Cyber Security Index of Latvia is still the lowest in the Baltic states (NCSI, 2019).

The research recommendations and observations aim to highlight the shortcomings of the development of the cybersecurity insurance market, emphasizing that an integrated approach is needed to address them. The authors propose that the principal insurance 
companies need to create a structured dialogue to highlight a harmonized framework and the main directions in developing the cybersecurity insurance market. Cooperation between the principal insurance companies would expedite the development of the cybersecurity insurance market, but as this is a competition issue, the possibility of applying such an approach is restricted.

Overall, the outcome of this research of the principal insurance companies provides useful insights on the growth potential, challenges and significant concerns of cybersecurity insurance in Latvia. Respondents of all levels emphasized their main concerns about the current cybersecurity insurance market and highlighted areas for further research and analysis. At the same time, the authors note that there is no clear and harmonized terminology among insurance companies for cybersecurity insurance. Moreover, there are limitations in insurance companies regarding sufficient technically skilled underwriters/brokers to build in-house expertise, which is one of the key findings. One factor that drives the complexity of the underwriting process is that cyber insurance is not a bulk product but is highly tailored to each customer (Franke, 2017).

The key findings from the survey of insurance companies' representatives are shown in Figure 1:

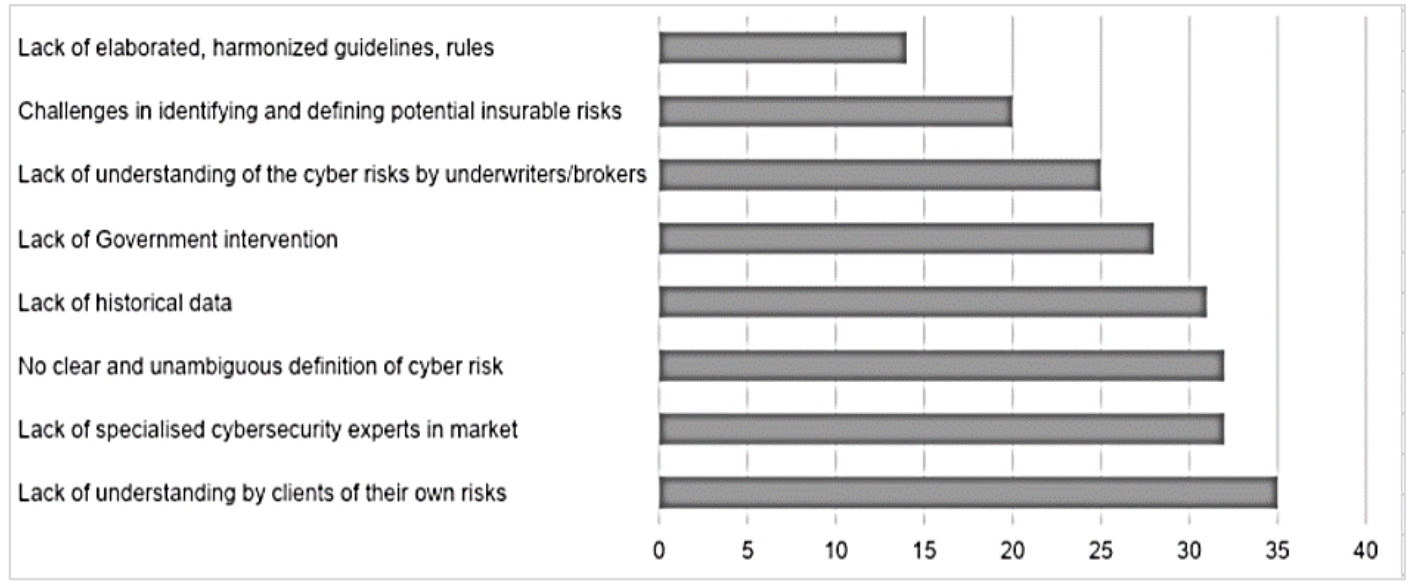

Figure 1 The sum of representatives' evaluations of the key findings on a scale of 1 to 8 (1 - lower importance, 8 - higher importance)

Source: survey conducted by the authors

The research highlights a need for an increased awareness of cyber risk on the supply and demand side. Cyber risk is a dynamic risk category that has substantially evolved over time; also, the protective processes and systems are fundamentally evolving (Eling et al., 2019). Lack of understanding by clients of their own risks related to cybersecurity is defined as the main key finding of the survey. Therefore, the key success factor for enhancing cybersecurity insurance development from the authors' point of view is commonly agreed terminology among insurance industry representatives around 
cybersecurity insurance key terms. This is also one of the preconditions for establishing common procedures and standards, without which a successfully functioning cybersecurity insurance market is not possible. However, the authors consider that insurance companies need to play a critical role in helping other companies understand potential consequences of cyberattacks and identify insurable cyber risks to increase overall company awareness of cybersecurity, in the form of seminars, educational materials, and conferences.

Cyber risk measurement and management is a challenge for insurance companies (Ruan, 2017). The authors agree that, by nature, a cybersecurity insurance product is a very complex type of insurance, in terms of both indemnification and regulation. Indeed, proper assessment and quantification of an organization's security situation is something that the information security industry has been struggling with for decades and which, to this day, remains elusive (Romanosky et al., 2019). All the respondents share the same opinion that the intangible and pervasive nature of cyber risks and their remodelling into traditional risk management forms and applying appropriate insurance coverage pricing are the primary challenges for insurance companies. The authors consider that international experience of insurance companies must be used to adapt risk management forms already in use. Insurance companies consider business liability coverage for a data breach as the most necessary category of cybersecurity insurance for businesses. At the same time, respondents of all levels were eager to point out that insurance policies could not be standardized but must be custom-based and tailored to the business of a particular company. This means that coverage and terms would vary (Bodin et al., 2018). The authors highlight it as one of cybersecurity insurance's limitations, as custom-based policies require additional time and work from the insurance companies' side.

Very low customer demand, an average of 1-2 applications per year, compared with the possible high cost of risk assessment and valuation from the insurers' side, is not facilitating the cybersecurity insurance offer currently, but at the same time, insurance companies expect a gradual increase in the demand for cybersecurity insurance, mainly driven by increased awareness of risks and by a higher frequency of cyber events. The impact of cybersecurity breaches is often not visible materially, which prevents their impact from being assessed in a sufficiently transparent manner from the outset. The respondents admitted that there is a very high possibility that customers who do not already understand the need for the simplest types of insurance for their business will not be motivated to spend financial resources on a cybersecurity insurance product, speculating that the occurrence of risks defined in the policy is impossible. The authors consider that demand is low due to the fact that insurance can defray only some of the costs of a data breach. As respondents also highlighted in the surveys, even the most comprehensive insurance policies will not ensure full coverage for a business, as provision of cybersecurity requires a strong security culture in companies.

While some insurance companies observe a potential for growth, they still prefer to adopt a careful approach in light of the uncertainties surrounding cyber risk, ranging from difficulties in risk modelling and prediction to adequate cost-effective pricing. There are 
many different processes influencing cybersecurity-related decisions inside a company. There are also many different factors, both internal and external, that can influence companies' cybersecurity decision-making and cyber insurance adoption (Labunets et al., 2020). Data and quantitative tools are key obstacles to the development of the cyber insurance industry. Insurers mentioned that lack of data (lack of sufficient amounts of claims data) is an important obstacle to a detailed understanding of fundamental aspects of cyber risk to build adequate models to assure accuracy in risk management. Organizations are wary of releasing too much information about their internal systems to prevent a decrease in reputation as well as leakage of knowledge about weaknesses of the system (Marotta et al., 2017).

From the authors' point of view, effective risk management is essential for success in enhancing cybersecurity insurance development and needs the involvement of the entire insurance industry, associations and the government to maximize data availability.

The authors consider that an important success factor driving cybersecurity insurance is emphasizing the cybersecurity insurance topic and its importance at the governmental level. A strong majority of insurance companies have confirmed that the government should play an important role in fostering good cybersecurity practices by strengthening cybersecurity strategy and in supporting the cybersecurity insurance market through policies and regulation.

From the authors' perspective, if there is no stable supply from the insurance companies' side for cybersecurity insurance products, new players could enter the market such as startups, which on the one hand could be potential partners, but on the other could be treated as competitors and might overtake this insurance industry segment.

\section{Expert interview analysis}

With the development of modern technology, cyberattacks have become an integral part of the business world, and the fight against these attacks has become a major challenge for many companies. The questions addressed in the interview with the CEO of a Latvian insurance company were as follows: How does one choose an appropriate protection system to help fight against them? Is cyber risk insurance a solution to protect a company from paralysis and cybercrime losses? Do companies in Latvia see a need for cybersecurity insurance, and are insurance companies in Latvia ready for it? In order to objectively assess the influencing factors related to cybersecurity insurance, the expert was mainly asked to speak about challenges and practical experience in implementing this product for more than five years.

The expert clarified that the company does not develop cybersecurity insurance products but finds appropriate solutions for the client. The company has been offering such a service, and he emphasizes that interest is gradually growing. Based on the expert interview it can be concluded that one of the primary caveats for an effective insurance 
product is a thorough understanding of the risk faced by policyholders. The biggest interest in cybersecurity insurance products is from the financial sector and companies with large databases, companies whose business depends on technology, and technology service providers. The main impact factors mentioned are the lack of public awareness of the importance of data and the possible consequences of cyberattacks. Simultaneously, the expert highlights that it is important to understand that cybersecurity insurance does not guarantee a reduction in the number of incidents but is only an additional safety pillow. One of the factors promoting the introduction of such a service is the need to educate the public more and talk about cyber protection measures and their need at the national level.

As an impediment, the expert mentions insufficient understanding of cybersecurity insurance and capacity among insurers and the relatively small size of the Latvian market, as well as the lack of real claims and litigation against companies, for example, for stolen data. From the expert's point of view, it will be five to ten years before cybersecurity insurance becomes more popular in Latvia.

\section{Latvian mobile operator survey results}

At the start of the questionnaire, all representatives of Latvian mobile operators were asked to rank in order of importance what they consider to be the greatest cybersecurity risks for their company (see Figure 2).

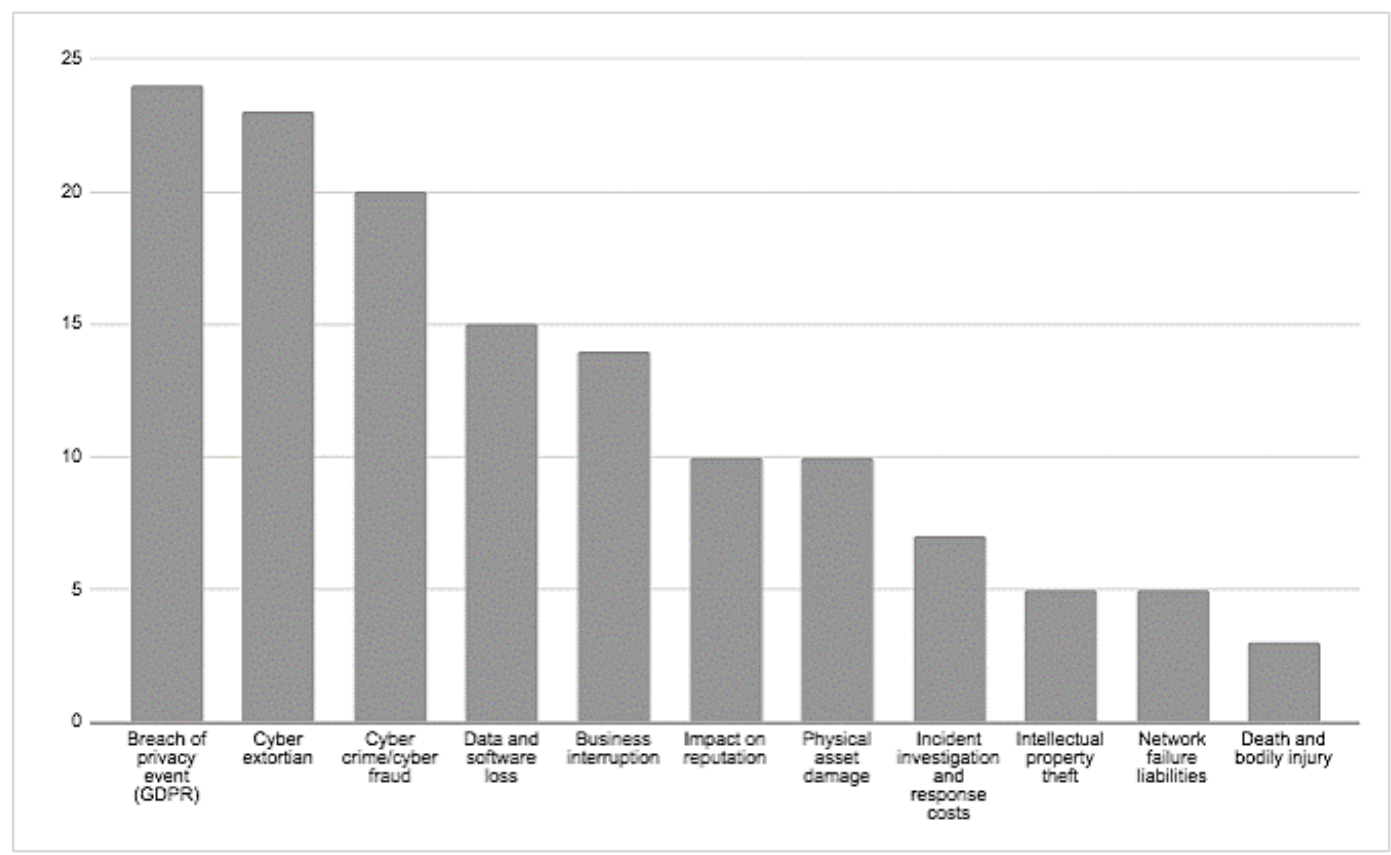

Figure 2 The sum of representatives' evaluations of the cybersecurity risks on a scale of 1 to 10 (1- lower importance, 10 - higher importance) Source: survey conducted by the authors 
Figure 2 provides insight on the top cyber threats all mobile operator representatives highlighted for their companies. In the framework of the research the authors followed up with questions for the representatives on acquiring cybersecurity insurance for their company. Representatives from 2 mobile operator companies stated that their company doesn't have cybersecurity insurance, but they would be interested to see the possible offers. One representative added that some cyber risks are already covered by their company's general insurance. Representatives whose companies would not be interested in cybersecurity insurance stated that they see cybersecurity insurance as a part of their business continuity plan, not as a separate product. Representatives also mentioned the poor reputation cybersecurity insurance policy cases have gained in the last decade, for instance, the 2011 cyberattacks on Sony involving the theft of personal data such as names, passwords and addresses from more than 100 customers (Independent, 2011). Sony's losses were reportedly estimated to be as high as $\$ 2$ billion. Despite having cyber liability coverage through the CGL (Commercial General Liability) policy at Zurich American Insurance Company, Sony did not receive compensation for the damages caused by the breach. The CGL policy covered actions taken by Sony, but since the breach was caused by third-party hackers, Zurich American was not obliged to reimburse Sony (Young, 2014). Therefore, the authors consider that in order to establish a better reputation for cybersecurity insurance policies and their liabilities, the Latvian Insurers Association could also play a significant role in promoting cybersecurity insurance by educating businesses about the complexity of policies and their coverage.

In the framework of this survey, of the 2 representatives who would be interested in cybersecurity insurance, only 1 could give an estimate on how much their company would be willing to spend for a cyber policy - estimating it at a price of around $0.005 \%$ of the company's yearly turnover. Representatives also suggested that the determining factors for choosing an insurance provider would be insurers' international experience as the most important factor, followed by a customized offer for their business model, and the insurance price as the least important factor.

Representatives who indicated their company's interest in cybersecurity insurance were asked questions about each loss category. Only 1 representative showed interest in insuring risk of intellectual property asset loss due to a cyberattack (expressed in terms of loss of revenue as a result of a reduced market share). For large organizations, intellectual property theft could have the most severe impact. Quantifying the damage caused by the loss of intellectual property or commercially sensitive information is challenging, because such assets are difficult to value, and the loss suffered by an organization depends on how the attacker uses the stolen information. Research conducted by the Oxford Economics team shows that not all industry sectors are attacked in the same way, with industries like defence, chemicals and pharmaceuticals, and creative media being more affected in case of intellectual property theft (Oxford Economics, 2014).

None of the representatives said they would be interested in insuring risk of business interruption, such as lost profits or extra expenses due to unavailability of IT systems. One 
representative later stated that such risk is covered under the insurance policy they already have. Also, none of the representatives showed interest in an insurance policy covering costs arising from cyber extortion and cybercrime/cyber fraud, including ransom payment, even if it is evident that representatives recognize it as one of the top cyber risks. But one representative said his company would be interested in insuring loss of revenue due to the impact on reputation after a cyberattack. Reputational damage is a relatively highfrequency event, as most cyber breaches can have a reputational impact if not handled adequately. It is also difficult to quantify damage of this nature, but the research team agrees that such events should be on companies' agendas since proper incident response can limit the severity of loss. Reputational damage accounts for around 5\%-20\% of the cost of a cybersecurity breach for large businesses. Organizations often overlook certain types of costs of breaches, and so may undervalue their true impact (University of Portsmouth, 2019).

One risk which all representatives indicated as being on their agenda - and 2 representatives stated they would be interested in having covered in cybersecurity insurance - is breach of privacy events, such as fines and penalties related to the European Union's General Data Protection Regulation (GDPR). One representative added that the GDPR has been a top priority for the past 2 years due to its topicality, but it would lose its popularity once everyone gets accustomed to it and more employees get educated in this matter. The research team also agrees that treating the GDPR as the main cybersecurity issue can give a false presumption of organizations' cyber awareness. Applying GDPR standards certainly has a positive effect on many organizations, making them more aware of the information they keep and how they handle it. But having GDPR training won't make any organization more cyberattack-resilient.

In this questionnaire, mobile operator representatives were also asked about their interest in insuring against physical asset damage to their physical property, and only 1 representative stated that they would most likely be interested in covering this risk with insurance. The research team agrees that not all businesses may be affected in the same way in the event of an attack on physical assets, but it should be noted that physical losses are a growing concern because of the interconnectedness of cyberspace and the physical world. An example of a physical loss resulting from a cyberattack is a steel mill in Germany where hackers managed to gain access to the control systems following a successful phishing attack, which targeted individuals for login details. Once access was secured, the hackers were able to cause an unscheduled shutdown of a blast furnace, which resulted in massive damage, according to the German Federal Office for Information Security (Song et al., 2017).

A condensed summary of this questionnaire suggests that 2 out of 3 mobile operators are interested in a cybersecurity insurance policy, but there are only a few risk categories, such as data breaches or the impact on reputation resulting from a cyberattack, that they are interested in insuring. Large companies like mobile operators already have devoted a lot of time and resources to their company's cybersecurity, so they don't see the benefit of 
cybersecurity insurance. So the data confirms the authors' observation that businesses in Latvia have low demand for cybersecurity insurance policies because of limited information on how such policies can mitigate cyber risks.

\section{CONCLUSIONS AND DISCUSSION}

With a joint analysis of all three sides - the only provider, the potential providers and the possible buyers - important concluding remarks have emerged. According to the research authors and the OECD data, the main challenges in the Latvian market are similar to those in the rest of the OECD countries, and the lack of cybersecurity insurance providers and the low demand from companies to acquire such insurance are a large factor in market growth (OECD, 2017).

There are several reasons for the undeveloped cyber insurance market in Latvia. The lack of historical knowledge and evolving nature of cyber risks create significant challenges in quantifying and expressing cyber threats in monetary value. An important impact factor for the cybersecurity insurance market is the lack of public awareness of cybersecurity risks. There is clearly a need for a more comprehensive understanding of cyber risks, on both the supply and the buyer's side, for the Latvian cybersecurity insurance market to grow further. It is not only about the treatment and assessment of risks, but also understanding businesses' and clients' needs. A set of standards, guidelines and policies could help to clarify what critical business functions should be insured with cybersecurity insurance and how risks interconnect with these functions.

One of the most important factors impacting the cybersecurity insurance market is the small size of the market. Due to the small number of possible purchasers of the product, there is also a trifling number of cybersecurity insurance brokers. The sole provider of cybersecurity insurance in Latvia has chosen to be a mitigator by connecting possible purchasers (those who have already bought the insurance already have high cybersecurity risk awareness) with cybersecurity insurance brokers and experts from abroad rather than hire a permanent office of cybersecurity insurance brokers. As a result, another impact factor of cybersecurity insurance market development is a lack of know-how for cybersecurity insurance in Latvia. Research shows that there is a low demand for cybersecurity insurance policies because of limited information on how cybersecurity insurance policies can mitigate cyber risks.

The research results indicate that the insurance industry is aware of the need for cybersecurity insurance. At the same time, the greatest challenge that all experts and the authors recognize is the need for companies to identify their risks and, first and foremost, perform a risk assessment in order to effectively protect businesses and information in this digital age. Insurance companies can't help to prevent data breaches, but with 
cybersecurity insurance they can help in transferring some of the cyber risks instead of the business taking on the risks by itself.

From the authors' point of view, the next stage for cybersecurity insurance development is to include regulatory claims and fines and penalties in the offer, thus making it more attractive and ensuring the demand growth necessary for the economic viability of cybersecurity insurance.

The authors also see the necessity for governmental involvement in developing cybersecurity insurance as of utmost importance. The public sector could pool data related to cyber risks, spread information (CERT.LV is already an existing platform) and create toolkits to inject stimulus for demand and supply of cybersecurity insurance. In the same category of information dissemination, greater media coverage, public education about cyber risks and lobbying from interested parties would also motivate the development of the cybersecurity insurance market in Latvia. Another way of increasing cybersecurity awareness and generating high standards of cybersecurity insurance is to follow the example of the British - introduce and enforce a certification programme (called Cyber Essentials in the UK), which would guide businesses in protecting themselves against cyber threats by setting out the basic technical controls that all organizations should have in place (Marsh, 2015). A common standard certification generated by CERT.LV would put all the companies with cybersecurity risks on the same page regarding requirements, creating a shared understanding of risks and thus cybersecurity insurance.

This research paper offers the beginning of a dialogue between experts, businesses and governance on a general framework and development of the main guidelines for cybersecurity insurance services. 


\section{REFERENCES}

1. Accenture Security (2019), Ninth Annual Cost of Cybercrime Study, available at: https://www.accenture.com/_acnmedia/PDF-96/Accenture-2019-Cost-of-CybercrimeStudy-Final.pdf\#zoom=50 (accessed 2 April 2020).

2. Anderson, R., Barton, C., Bohme, R., Ganan, C., Grasso, T., Levi, M., Moore, T. and Vasek, M. (2019), "Measuring the Changing Cost of Cybercrime", The 18th Annual Workshop on the Economics of Information Security, available at https://www.repository.cam.ac.uk/handle/1810/294492 (accessed 29 February 2020).

3. Armerding, T. (2015), "Why criminals pick on small business", CSO, 12 January, available at: https://www.csoonline.com/article/2866911/why-criminals-pick-on-small-business.html (accessed 2 April 2020).

4. Bodin, L., Gordon, L. A., Loeb, M. P. and Wang, A. (2018), "Cybersecurity insurance and risk-sharing”, Journal of Accounting and Public Policy, Vol. 37, No. 6, pp. 527-544.

5. Central Statistics Bureau (2020), Iekšzemes kopprodukts, available at: https://www.csb.gov.lv/lv/statistika/statistikas-temas/ekonomika/ikp (accessed 27 March 2020).

6. Eling, M., Wirfs, J. (2019), “What are the actual costs of cyber risk events?”, European Journal of Operational Research, Vol. 272, No. 3, pp. 1109-1119.

7. FICO (2018), The Nordics. Views from the C-Suite Survey, available at: https://www.fico.com/en/latest-thinking/ebook/nordics-views-c-suite-survey-2018 (accessed 16 February 2020).

8. Franke, U. (2017), "The cyber insurance market in Sweden", Computers and Security, Vol. 68, pp. 130-144.

9. The Independent (2011), "Sony battles to regain trust after data breach", 18 September, available at: https://www.independent.co.uk/life-style/sony-battles-to-regain-trust-afterdata-breach-2283560.html (accessed 2 April 2020).

10. Labunets, K., Pieters, W., Eeten, M., Branley-Bell, D., Coventry, L., Briggs, P., Martínez, I. and Sewnandan, J. (2020), Security Risk Models for Cyber Insurance, Routledge, Abingdon, pp. 11-26.

11. Marotta, A., Martinelli, F., Nanni, S., Orlando, A. and Yautsiukhin, A. (2017), "CyberInsurance Survey”, Computer Science Review, DOI: 10.1016/j.cosrev.2017.01.001, ISBN: 1574-0137. 
12. Marsh (2015), UK Cyber Security: The Role of Insurance in Managing and Mitigating the Risk, available at: https://www.marsh.com/uk/insights/research/uk-cyber-security-role-ofinsurance-in-managing-mitigating-risk.html (accessed 2 February 2020).

13. Matthew, A. (2019), “Cyber Insurance”, International Journal of Engineering and Advanced Technology, Vol. 8, No. 6, pp. 47-51.

14. NCSI (2019), National Cyber Security Index, available at: https://ncsi.ega.ee/country/lv/ (accessed 4 April 2020).

15. NetDiligence (2018), Cyber Claims Study, available at: https://netdiligence.com/wpcontent/uploads/2018/11/2018-NetDiligence-Claims-Study_Version-1.0.pdf (accessed 17 February 2020).

16. OECD (2017), "Cyber insurance market challenges", Enhancing the Role of Insurance in Cyber Risk Management, OECD Publishing, Paris.

17. Oxford Economics (2014), Cyber-attacks: Effects on UK Companies, available at: https://www.oxfordeconomics.com/recent-releases/cyber-attacks-effects-on-uk (accessed 2 April 2020).

18. The Public Utilities Commission (2019), TOP 8: Kas mainijies telekomunikaciju operatoru darbiba un sniegtajos pakalpojumos?, available at: https://www.sprk.gov.lv/events/top-8kas-mainijies-telekomunikaciju-operatoru-darbiba-un-sniegtajos-pakalpojumos (accessed 10 April 2020).

19. Research and Markets (2020), Cyber Insurance Market by Component (Solutions (Analytics and Cybersecurity) and Services), Type (Standalone and Packaged), Coverage (Data Breach and Cyber Liability), Organization Size, End User (Technology and Insurance), and Region - Global Forecast to 2025, available at https://www.researchandmarkets.com/reports/5178517/cyber-insurance-market-bycomponent-solutions (accessed 21 February 2020).

20. Romanovsky, S., Ablon, L., Kuehn, A. and Jones, T. (2019), "Content Analysis of cyber insurance policies: how do carriers price cyber risk?", Journal of Cybersecurity, Vol. 5, No. 1, pp. 1-19.

21. Ruan, K. (2017), "Introducing cybernomics: A unifying economic framework for measuring cyber risk", Computers and Security, Vol. 65, pp. 77-89.

22. Song, H., Glenn, A., Fink, G. A. and Jeschke, S. (2017), "Security and Privacy", in CyberPhysical Systems: Foundations, Principles, and Applications, John Wiley and Sons, Hoboken.

23. University of Portsmouth, Department for Digital, Culture, Media and Sport (2019), Cyber Security Breaches Survey, available at: https://assets.publishing.service.gov.uk/government/uploads/system/uploads/attachment_d 
ata/file/875799/Cyber_Security_Breaches_Survey_2019_-_Main_Report_-_revised.pdf (accessed 2 April 2020).

24. Young, H. (2014), "N.Y. Court: Zurich Not Obligated to Defend Sony Units in Data Breach Litigation", Insurance Journal, 17 March, available at:

http://www.insurancejournal.com/news/east/2014/03/17/323551.htm (accessed 2 April 2020). 


\section{Financial sector reform (2016-2019): The impact on Latvian banks}

JEKATERINA SNEIDERE

IVARS GODMANIS

\section{ABSTRACT}

The purpose of this research is to get the first results on the impact of the recent financial sector reform started in 2016 by the Latvian FCMC (Financial and Capital Market Commission) and the Latvian government on the performance of two traditional Latvian banking groups: resident and non-resident banks. The main objective is to find out how the outflow of non-resident deposits caused by the reform has affected both banking groups' main performance indicators: the capital adequacy ratio (CAR) and return on equity (ROE).

The methodology of the research involves obtaining ROE and CAR parameters in the whole Latvian banking sector before and during the recent financial sector reform and analyzing these parameter dynamics and differences, particularly for resident and non-resident banks.

The results obtained clearly demonstrate that the recent reform of the Latvian financial sector has affected resident and non-resident bank performance in Latvia very differently.

The outflow of non-resident deposits during the reform implementation has made a minimal impact on the performance of resident banks, but significantly affected non-resident banks, triggering a decline in their total assets, total deposits, and profitability.

The results obtained show some "recovery" of non-resident bank performance at the second stage of reform (after 2017), which could demonstrate the reorientation of their business models agreed with the FCMC. However, there is a need for further research to be sure that this process will be sustainable.

Keywords: Latvian banking sector, financial sector reform, non-resident deposits, AML/CTPF, non-resident banks. 


\section{INTRODUCTION}

An ambitious Latvian financial reform was started in 2016 with the aim to improve the reputation of the Latvian banking sector, which historically consists of two traditional groups: resident and non-resident banks.

Implementation of this reform by the Latvian government and the Financial and Capital Market Commission (FCMC) was based on OECD criticism (2015) of the shortcomings in Latvia's AML/CTPF (anti-money laundering / counter terrorism and proliferation of weapons of mass destruction financing) system, the European Parliament and Council AML IV Directive (2015) and the MONEYVAL report (2018) regarding the large crossborder flow of financial resources through Latvian banks, insufficient measures to fight corruption, poor quality of reports on unusual and suspicious transactions, shortcomings in customer due diligence, and risks related to circumvention of international sanctions.

By implementing the reform, the Latvian FCMC began to tighten up its assessment of bank compliance with the AML/CTPF standards and increased the amount of fines for violations of AML/CTPF.

The share of non-resident deposits in the Latvian bank total portfolio was significantly high (53\% in 2015) and therefore particular attention in this reform was given to 12 nonresident banks in Latvia, which became subject to AML/CTPF inspections by independent advisory firms from the United States. During the implementation of the reform, major changes have been made in the legislation governing AML/CTPF, such as the clarification of the definition of politically exposed persons to include residents and the prohibition to cooperate with shell companies if they exhibit a certain set of characteristics.

The goal of this research is to obtain the first results of the impact of the Latvian financial sector reform (2016-2019) on the performance of Latvian banks and analyze the differences of this impact in resident and non-resident banks.

The research questions are as follows: What are the main consequences of the recent financial sector reform in Latvia for the whole banking sector? Are there any essential differences in the performance of the traditional two groups of banks (resident and nonresident) during the reform implementation? What could be the future of non-resident banks and their further business strategy in Latvia?

\section{Theoretical background}

The capital adequacy ratio (CAR) is one of the most important bank performance parameters in modern international banking regulation, which is the focus of more than 100 national central banks and banking supervisors (Diamond and Rajan, 2000). By 
definition, capital requirements are rules that limit the amount of leverage and risk that banks can take, as well as the level of capital adequacy that banks must achieve (Howarth and Quaglia, 2013).

Basel III regulations (Basel Committee on Banking Supervision, 2011) set minimum reserves above the minimum capital requirement: the countercyclical capital buffer to be built up during economic upturns and to be used during downturns, as well as the capital conservation buffer (Repullo and Suarez, 2013). The structure of the minimum capital requirement and additional reserves is shown in Figure 1.

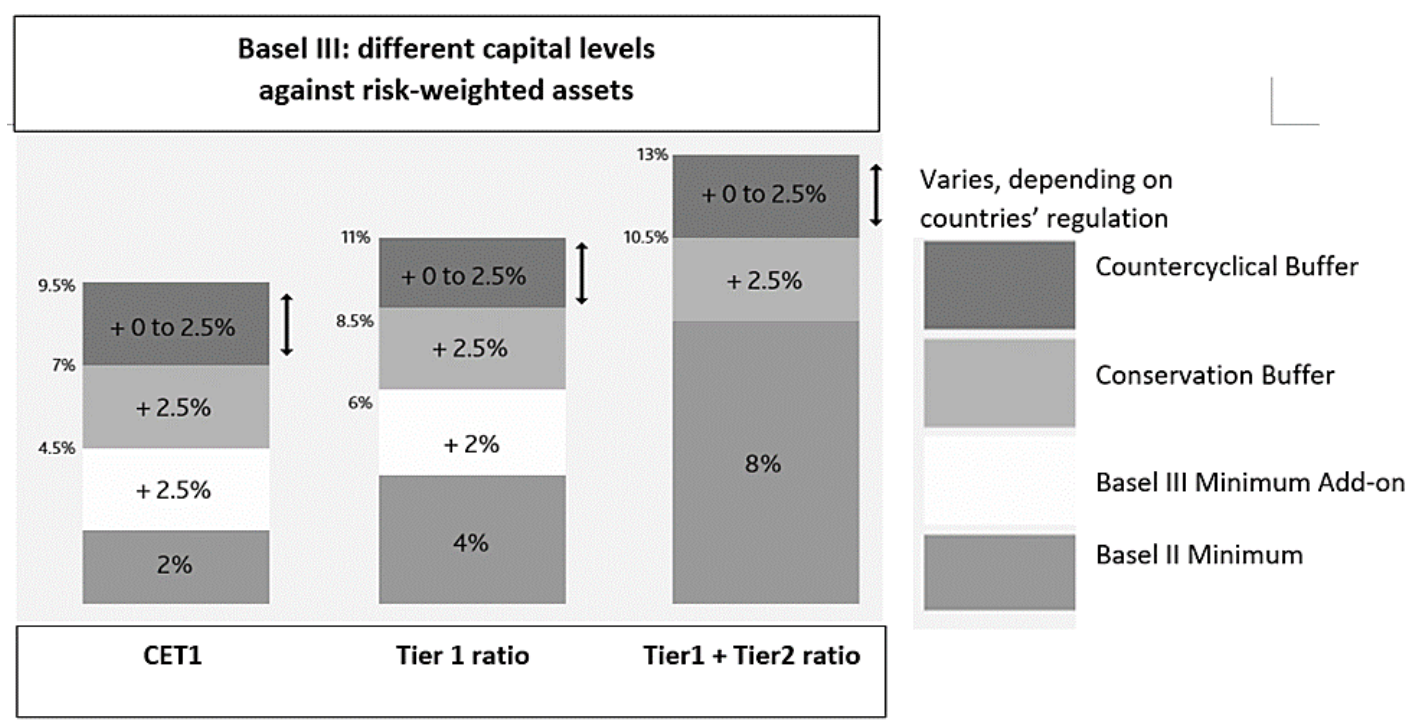

Figure 1 Basel III requirements for CAR

(Moody's Analytics, 2013)

In general, capital requirements for Latvian banks coincide with the requirements set out in the Basel III framework. However, there are differences that are characteristic of the EU capital regulation and the requirements set by the Latvian FCMC: the minimum CET1 and Tier 1 capital ratios have been raised to $4.5 \%$ (from $2 \%$ ) and $6 \%$ (from $4 \%$ ); the countercyclical capital buffer in Latvia was set at $0 \%$ in order to stimulate more lending (Financial and Capital Market Commission, 2012-2018). The total capital requirements binding on Latvian banks are shown in Figure 2. 


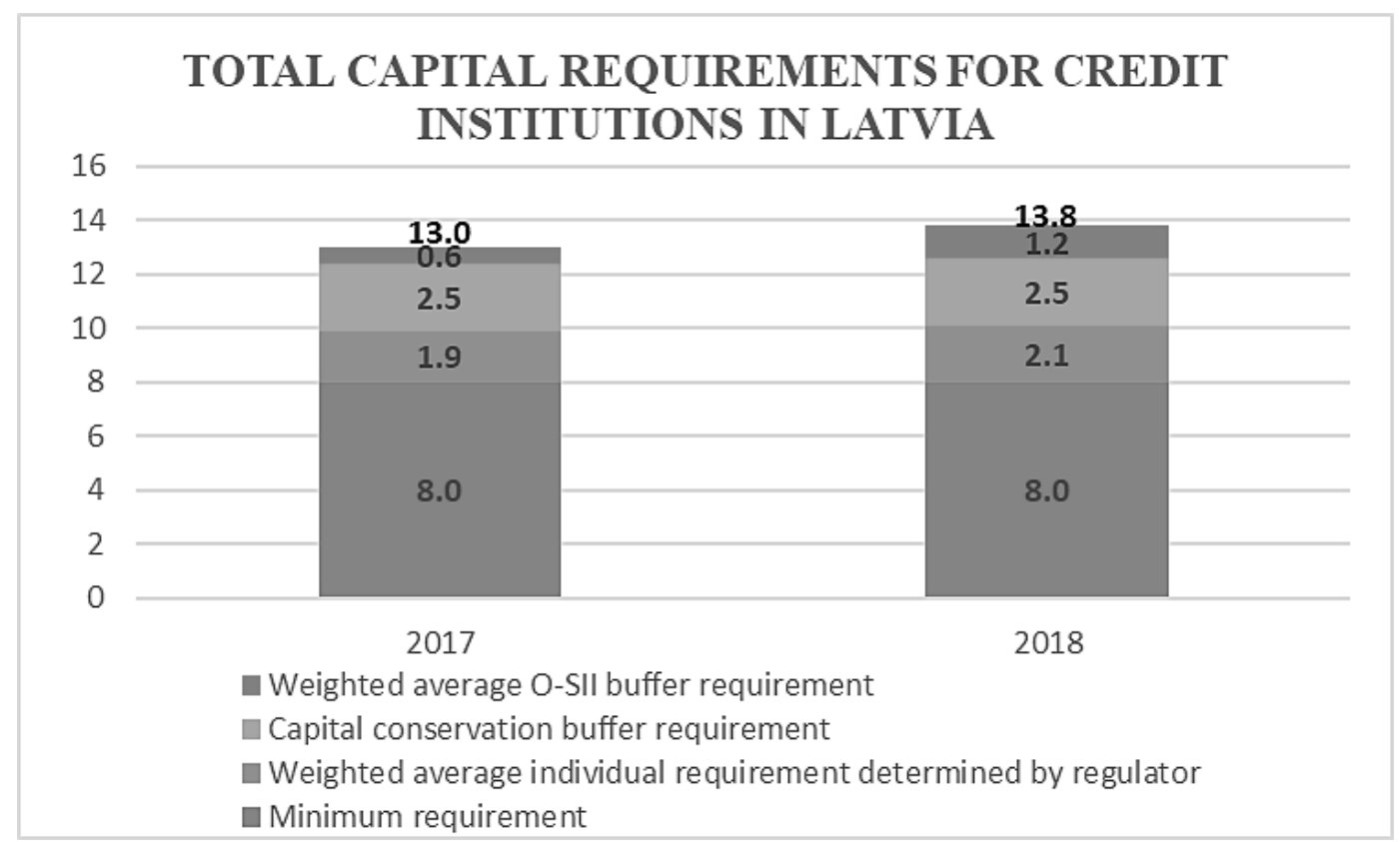

Figure 2 Total capital adequacy ratio (CAR) requirements for Latvian banks

(Bank of Latvia, 2019)

The asymmetric impact of Basel capital requirements on large and small banks is widely discussed. It has been emphasized that the same capital requirements for all banks, regardless of their size, distorts competition between different categories of banks and the impact of the same capital requirements on small and large banks is asymmetric (Hakenes and Schnabel, 2011).

There is a point of view (Haufler and Maier, 2016) that higher capital standards will lead to the consolidation of the banking sector as smaller or weaker banks exit the market.

A study on the factors contributing to the profitability of Central and Eastern European banks in the period from 2000 to 2013 (Djalilov and Piesse, 2016) shows that Baltic banks (including Latvian banks) are characterized by a positive effect of capital adequacy ratios on banks' ability to generate higher profits.

However, there is also the opposite view that increasing capital requirements run the risk of reducing investment and bank lending, which ultimately reduces their profitability (Kashyap and Stein, 2004). Another study on bank capital requirements reveals that higher capital requirements for banks significantly reduces their lending capacity, which in turn has a negative impact on profits (Fraisse et al., 2017).

Analysis of bank profitability indicates that the most common determinants of banks' ability to generate profits are the size of the banks (in terms of their assets), such risk indicators as credit risk and liquidity risk, and capital ratios (Djalilov and Piesse, 2016). 
Banks' profitability is usually assessed by calculating indicators such as the ratio of a bank's financial result (net profit) to the amount of resources used - return on equity (ROE) (Casu et al., 2006).

The ROE indicator describes the efficiency of the use of equity and determines the level of return on shareholders' funds invested in the bank. It is calculated according to Formula 1 (European Central Bank, 2010):

$$
R O E=\frac{\text { Net Profit }}{\text { Capital and Reserves }} * 100 \%
$$

\section{METHODOLOGY}

The research is based on the financial data statistics of Latvian banks from the banks' individual public quarterly reports for the period from 2012 to 2018, available on the FCMC website (Financial and Capital Market Commission, 2012-2018).

Banks were divided into two groups as defined by the FCMC (Financial and Capital Market Commission, 2019). The first group (Group 1) includes banks with a share of nonresident deposits of less than $20 \%$ (resident banking group) while the second group (Group 2 ) is comprised of banks focused on servicing foreign customers with non-resident deposits exceeding $20 \%$ in the total deposit base (non-resident banking group). The breakdown of individual banks into resident (1) or non-resident (2) banks can be seen in Table 1.

Table 1

Breakdown of Latvian banks into resident (1) and non-resident (2) banking groups 2012-2018

\begin{tabular}{lccccccc}
\hline & $\mathbf{2 0 1 2}$ & $\mathbf{2 0 1 3}$ & $\mathbf{2 0 1 4}$ & $\mathbf{2 0 1 5}$ & $\mathbf{2 0 1 6}$ & $\mathbf{2 0 1 7}$ & $\mathbf{2 0 1 8}$ \\
\hline ABLV Bank* & 2 & 2 & 2 & 2 & 2 & 2 & - \\
\hline Baltic International Bank & 2 & 2 & 2 & 2 & 2 & 2 & 2 \\
\hline BlueOrange Bank & 2 & 2 & 2 & 2 & 2 & 2 & 2 \\
\hline Citadele banka & 2 & 2 & 2 & 2 & 2 & 2 & 1 \\
\hline Expobank & 2 & 2 & 2 & 2 & 2 & 2 & 2 \\
\hline LPB Bank & 2 & 2 & 2 & 2 & 2 & 2 & 2 \\
\hline Luminor Bank AS ** & 1 & 1 & 1 & 1 & 1 & 1 & 1 \\
\hline Meridian Trade Bank *** & 2 & 2 & 2 & 2 & 2 & 2 & 2 \\
\hline PNB Banka **** & 2 & 2 & 2 & 2 & 2 & 2 & 2 \\
\hline PrivatBank & 2 & 2 & 2 & 2 & 2 & 2 & 2 \\
\hline & & & & Continued on the next page
\end{tabular}


Table 1 (continued)

\begin{tabular}{llllllll}
\hline Reǵionālā investīciju banka & 2 & 2 & 2 & 2 & 2 & 2 & 2 \\
\hline Rietumu Banka & 2 & 2 & 2 & 2 & 2 & 2 & 2 \\
\hline Rigensis Banka & 2 & 2 & 2 & 2 & 2 & 2 & 2 \\
\hline SEB banka & 1 & 1 & 1 & 1 & 1 & 1 & 1 \\
\hline Signet Bank AS ***** & - & - & 2 & 2 & 2 & 2 & 2 \\
\hline Swedbank & 1 & 1 & 1 & 1 & 1 & 1 & 1 \\
\hline Trasta Komercbanka $* * * * * *$ & 2 & 2 & 2 & 2 & - & - & - \\
\hline
\end{tabular}

* The bank's self-liquidation commenced in 2018; ** Established in 2017 by the merging of DNB Bank and the Latvian branch of Nordea Bank, until then - DNB Bank; ***until 2014 SMP Bank; **** until 2017 - Norvik Bank; ***** established in 2013, until 2017 - Bank M2M Europe; ****** The bank's operations were suspended in 2016.

(Source: compiled by the authors)

Dynamics of total deposits and capital adequacy ratio (CAR) as well as return on equity (ROE) in Latvian banks have been monitored before and during financial reform implementation and analysis has been made for resident and non-resident banks in particular.

\section{RESULTS AND DISCUSSION}

\section{Deposit dynamics in Latvian banks during the period of 2014-2019}

The results obtained show (see Figure 3) that in the period of 2015-2019, the amount of total deposits in the whole banking sector fell by $31 \%$ (from 22.6 billion EUR to 15.7 billion EUR), while the dynamics of resident and non-resident deposits were completely the opposite: non-resident deposits fell by $74 \%$ (from 12.1 billion to 3.2 billion EUR), but resident deposits grew by $17 \%$ (from 10.5 billion EUR to 12.4 billion EUR).

The structure of deposits in the whole Latvian banking sector fundamentally changed: the share of non-resident deposits decreased more than 3 times (from 54\% to 17\%) and consequently, the share of resident deposits increased 2 times (from $46 \%$ to $83 \%$ ). 


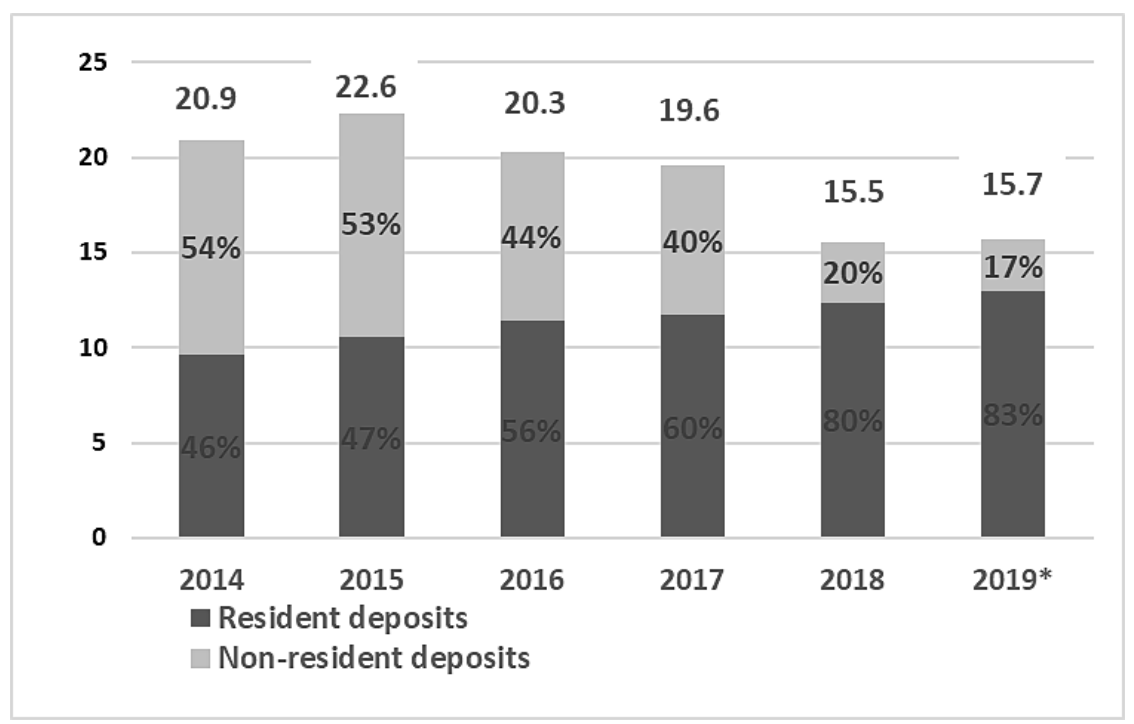

Figure 3 Structure of deposits attracted by Latvian monetary financial institutions, 2014-2019 (EUR billion) (Bank of Latvia, 2014-2019)

(compiled by the authors)

The sharpest drop in total deposits (21\%) was observed in 2018, partly due to the termination of ABLV Bank's activities (see Figure 4).

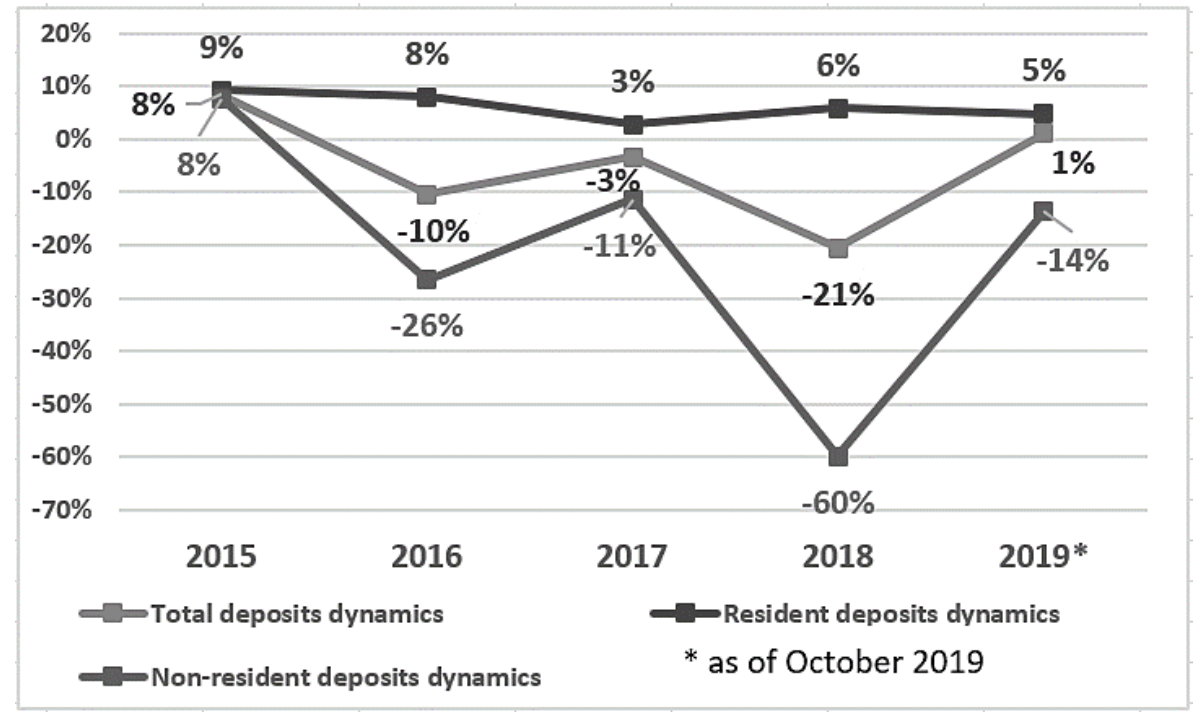

Figure 4 Dynamics of deposits attracted by Latvian monetary financial institutions, 2015-2019 (\%) (Bank of Latvia, 2014-2019) (compiled by the authors)

As a result of the financial sector reform, with the significant decline in the total amount of deposits (comprising mainly those of non-residents), the Latvian banking sector's total assets have been decreasing since 2016 (see Figure 5). 


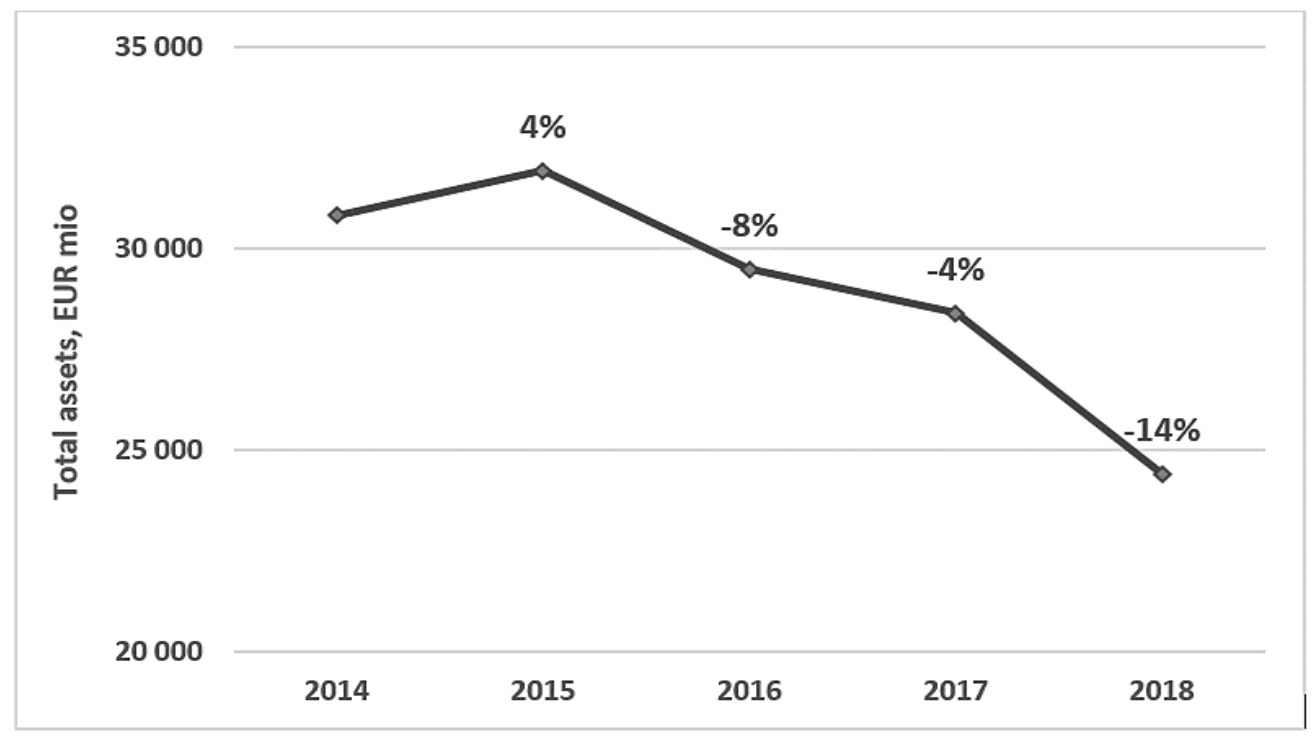

Figure 5: Dynamics of the total gross assets of the banking sector, 2014-2018 (EUR million, \%) (Finance Latvia Association, 2012-2018; Rietumu Bank JSC, 2019)

(compiled by the authors)

Comparing the dynamics of total deposits and total assets in both banking groups (see Figure 6), we can see that the financial sector reform, which started in 2016, had a completely opposite impact on resident and non-resident banks: a significant decrease in total deposits and total assets in the non-resident banking group (of 12\% (2016) and 28.7 $\%$ (2018)) and consequent increase in the resident bank group (of 2.2\% (2017) and of 6.4 $\%$ (2018)).

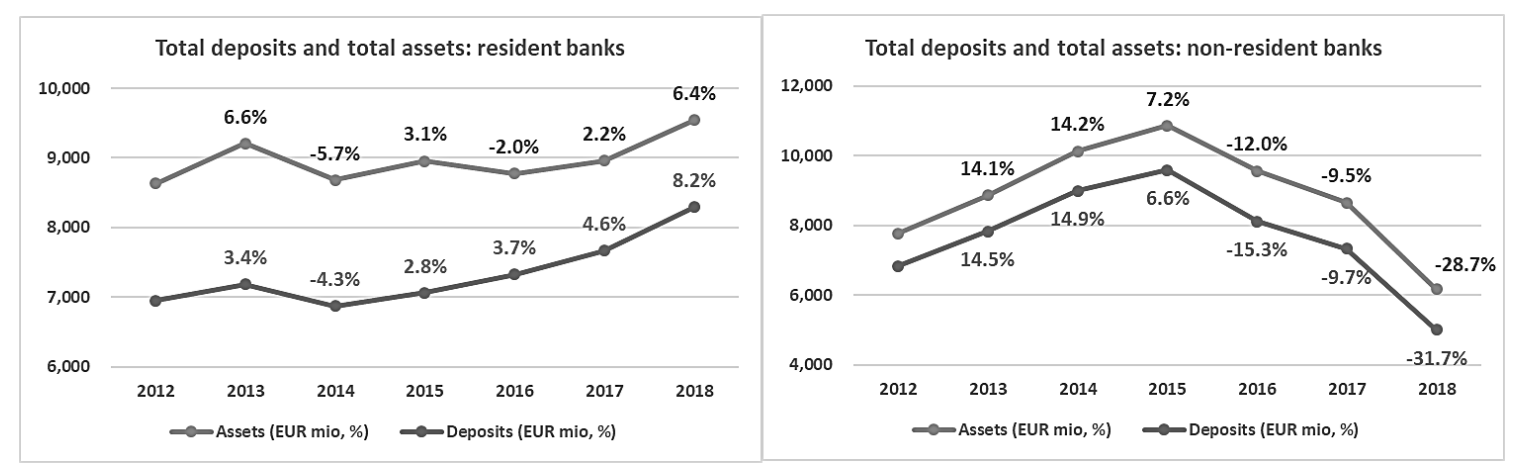

Figure 6: Dynamics of total deposits and total assets of resident banks and nonresident banks, 2012-2018 (EUR million, \%) (Financial and Capital Market Commission, 2012-2018) (compiled by the authors) 
It is important to clarify whether the effect of the shrinking non-resident deposits in the two traditional Latvian banking groups (the resident and non-resident banks) has been similar or different. The information compiled by the FCMC (see Figure 7) clearly shows that the rapid decline in non-resident deposits has taken place only in the non-resident bank group, while non-resident deposits did not decrease in the resident bank group.

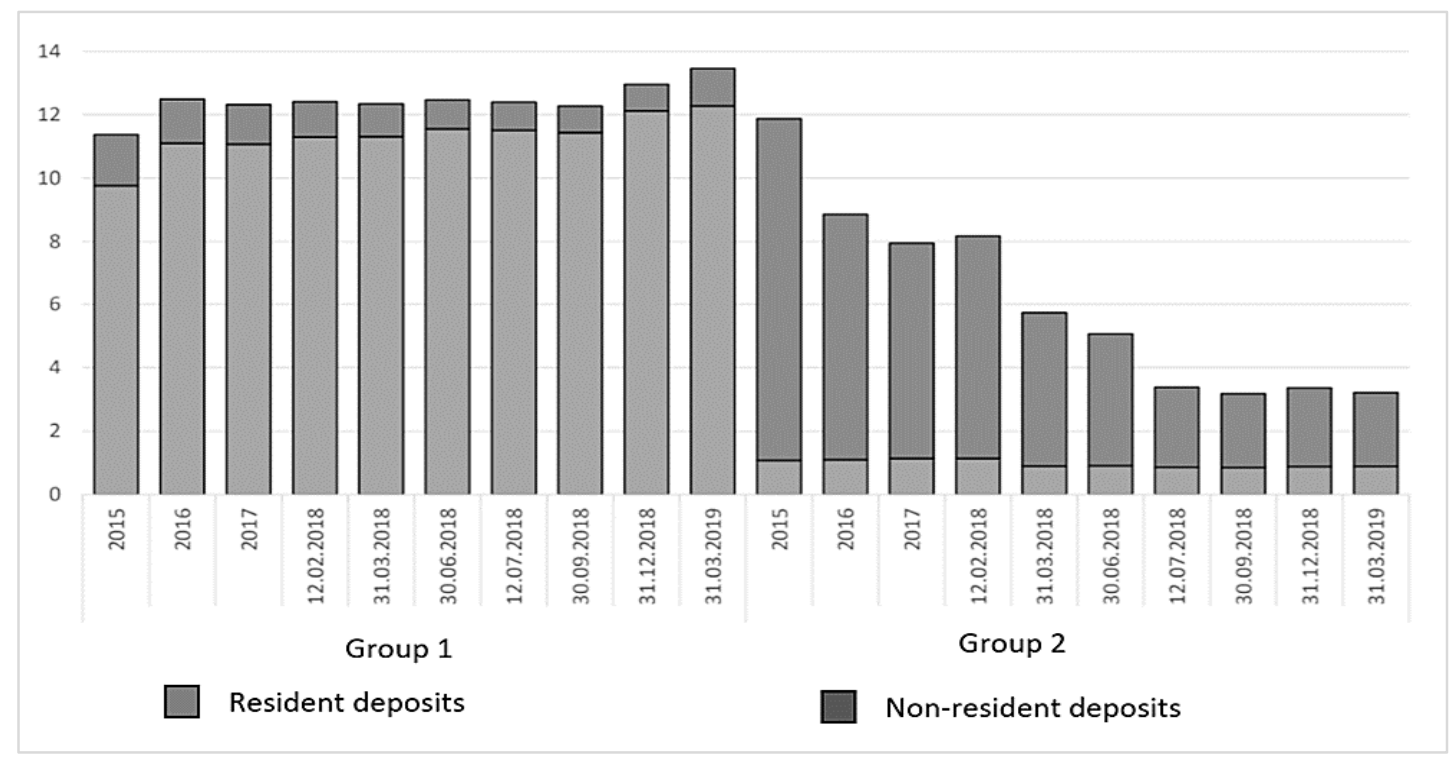

Figure 7 Dynamics of resident and non-resident deposits in the resident and nonresident banking groups (EUR billion) (Financial and Capital Market Commission, 2019)

The share of non-resident deposits in resident banks had already been below the limit of $20 \%$ prior to the commencement of the reform. The fact that with the reinforcement of the reform (including AML/CTPF measures, the prohibition to cooperate with shell companies) the volume of non-resident deposits in the resident banking group has not changed significantly may lead to speculation that the "quality" of foreign customers in resident banks could have been higher than in non-resident banks. However, such statistics are not publicly available, and further investigation is needed to prove it.

\section{CAR dynamics of Latvian banks in the period of 2012-2018}

The average capital adequacy ratio (CAR) of the whole Latvian banking system during the period from 2012 to 2018 significantly exceeded the minimum capital requirement of $8 \%$ set by the Basel III regulation and the FCMC, while the minimum capital requirement together with the capital maintenance reserve of $2.5 \%$ was introduced by the FCMC in accordance with Basel III and the EU capital regulation (see Figure 8). 


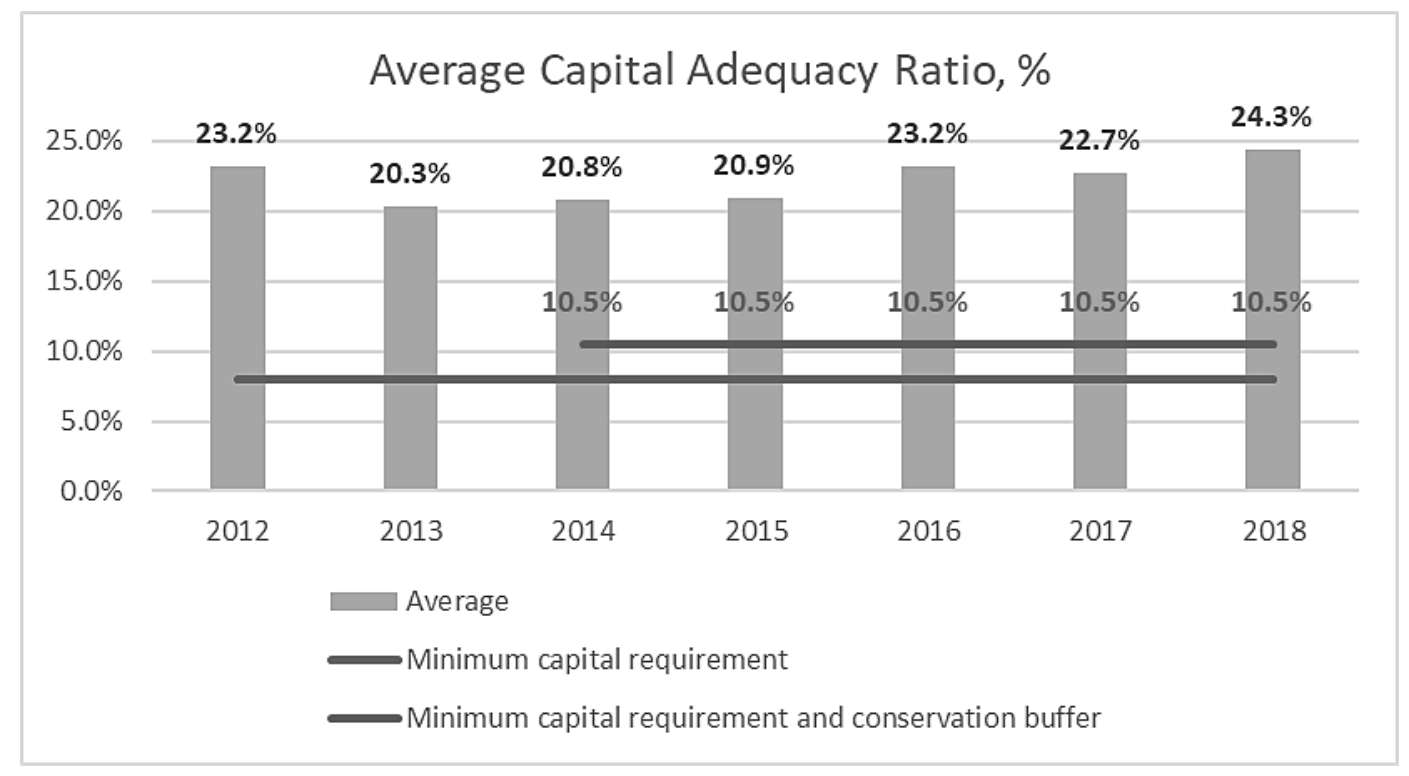

Figure 8: Average CAR value in the whole Latvian banking sector (Financial and Capital Market Commission, 2012-2018) (compiled by the authors)

However, CAR dynamics in resident and non-resident banks in Latvia before and during the financial reform showed a different pattern.

CAR values of the resident banking group varied from $12.5 \%$ (2012) to $39.3 \%$ (2015) (see Figure 9), but even the minimum CAR value was at least 4.5 percentage points above the minimum capital requirement (8\%). 


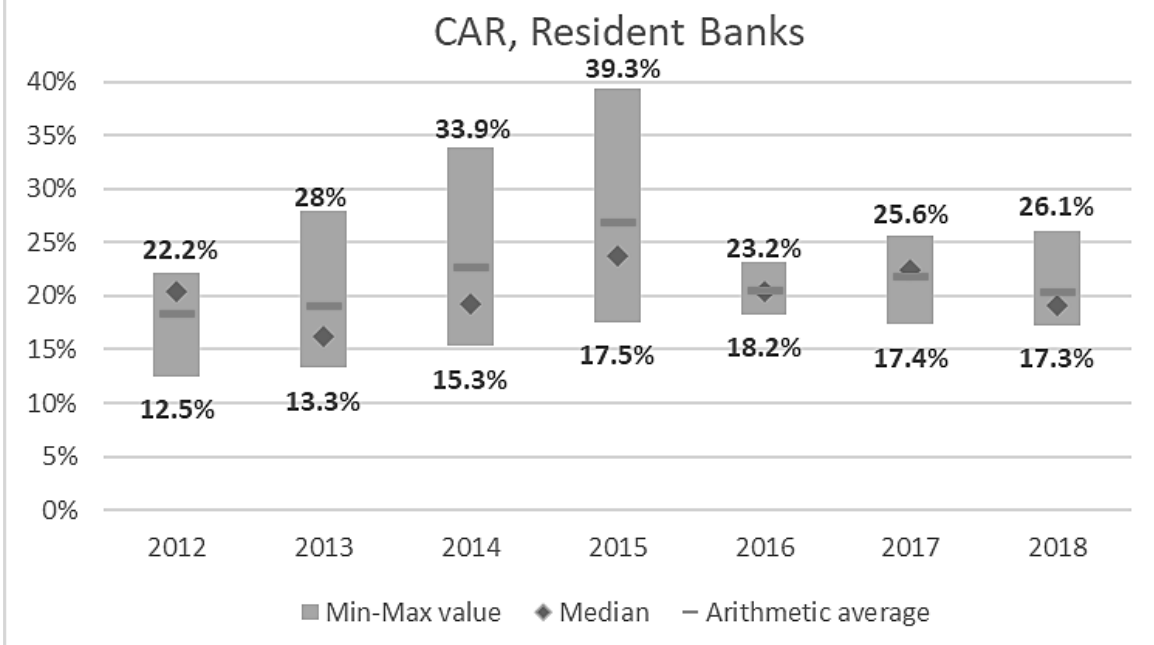

Figure 9: CAR values of resident banks (Financial and Capital Market Commission, 2012-2018) (compiled by the authors)

CAR values of the resident banking group consequently increased from $22.2 \%$ (2012) to $39.3 \%$ (2015) but then experienced a sharp drop in $2016^{1}$ and later increased slightly.

During the entire period (2012-2018), CAR values of resident banks were always above the minimum CAR required by the FCMC and even the minimum CAR values of particular resident banks were 4.5 percentage points above the minimum required CAR $(8 \%)$.

CAR values of the non-resident banking group for the same period of 2012-2018 were subject to greater divergence and more often approached the minimum capital requirement. In the years 2012-2015 and 2018 their CAR values were even below the required 10.5\% (see Figure 10) (an indicator which includes the minimum capital requirement of $8 \%$ and the capital maintenance reserve of $2.5 \%$ ).

\footnotetext{
${ }^{1}$ The sharp drop in CAR in 2016 was not caused by reform implementation but by a one-off decision from Swedbank to lower its capital (Swedbank JSC, 2017).
} 


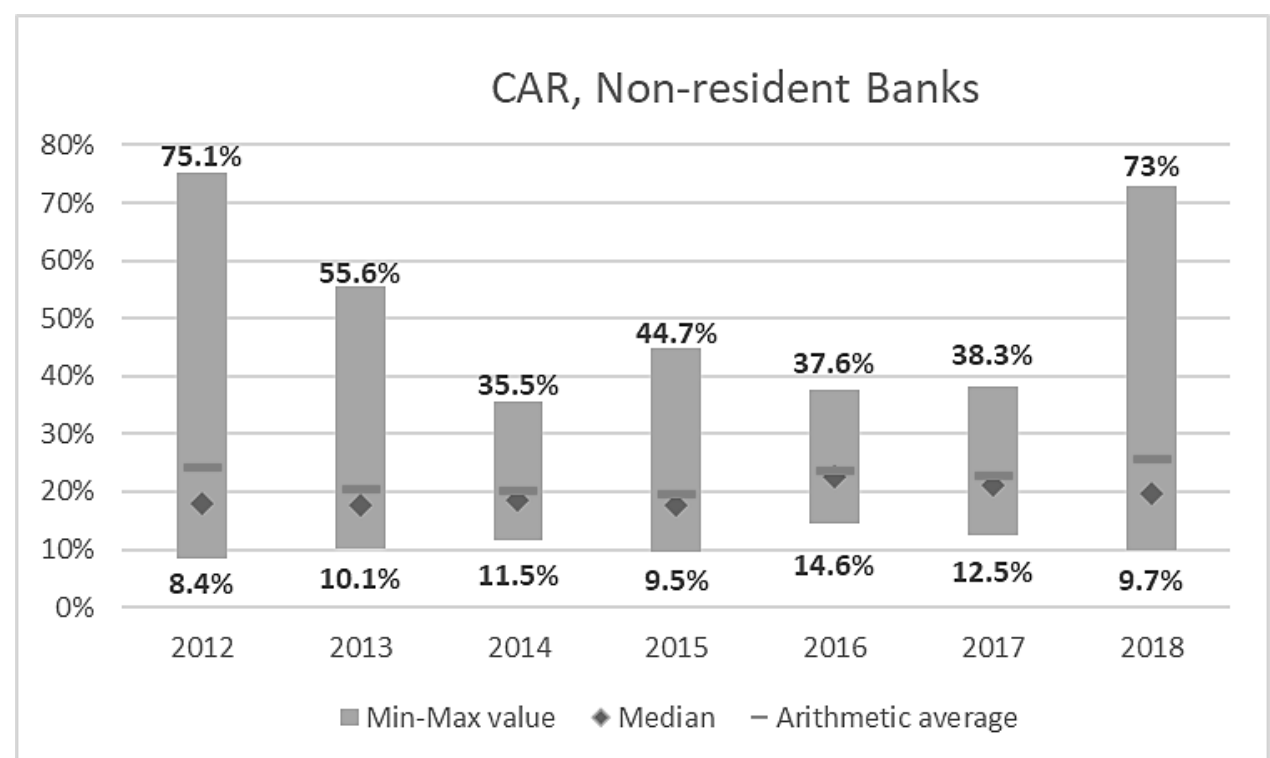

Figure 10 CAR values of non-resident banks in Latvia (2012-2018) (Financial and Capital Market Commission, 2012-2018) (compiled by the authors)

The results obtained demonstrate that during the period of reform implementation, CAR values of all resident banks were always over the required minimum level of $10.5 \%$ and were characterized by less dispersion and higher stability, which was mainly the result of their high level of capitalization, choice of conservative capital instruments and transparent capital structure, stable profitability, and significant excess of interest income over commission income.

CAR values of non-resident banks during the same period were more widely dispersed and for some banks the capital level even before and during the years of financial reform was below the minimum capital requirement, which could be explained by the use of Tier 2 capital instruments by non-resident banks, raising additional capital (incl. subordinated bonds and subordinated loans).

Differences obtained in CAR values and the dynamics of the two banking groups demonstrate that the more volatile non-resident bank business model is more exposed to the impact of financial sector reform than the resident bank model.

\section{ROE dynamics of Latvian banks in the period of 2012-2018}

The average ROE of the whole Latvian banking sector during the period of 2013-2018 was stable, varying between $13.8 \%$ and $15.3 \%$ (see Figure 11). 


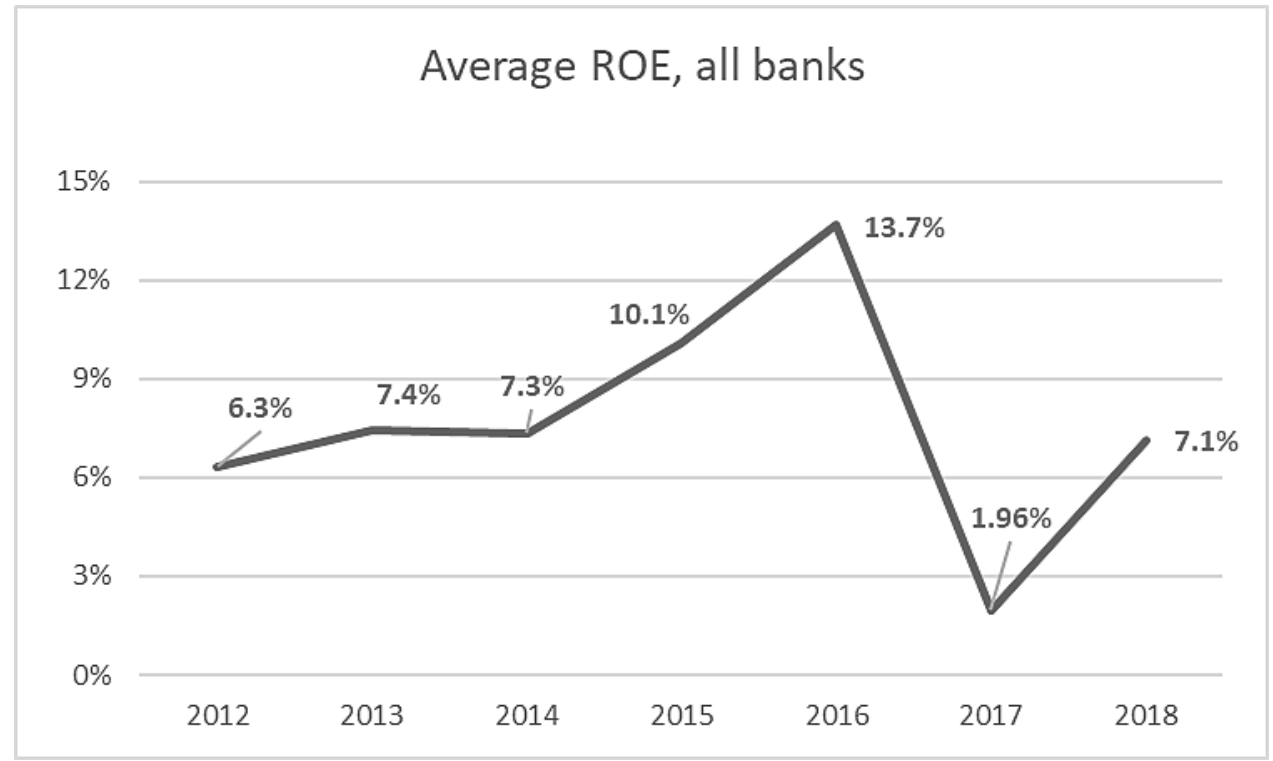

Figure 11 Average ROE value in the whole Latvian banking sector (2012-2018) (Financial and Capital Market Commission, 2012-2018) (compiled by the authors)

At the same time, ROE values and their dynamics showed different patterns in resident and non-resident banks.

The average ROE for resident banks during the period of 2012-2018 was more stable: the arithmetic average value of ROE ranged from 7\% in 2013 to $12 \%$ in 2018 and was almost always positive in all the years considered. ${ }^{2}$ (Figure 12)

\footnotetext{
${ }^{2}$ The exception is the operating result of Luminor bank in 2017, which is mainly related to the merger of DNB bank and the Latvian branch of Nordea Bank AB, which had an impact on the financial results of the combined bank due to one-time costs, incl. from investments in property and impairment losses (Luminor bank JSC, 2018).
} 


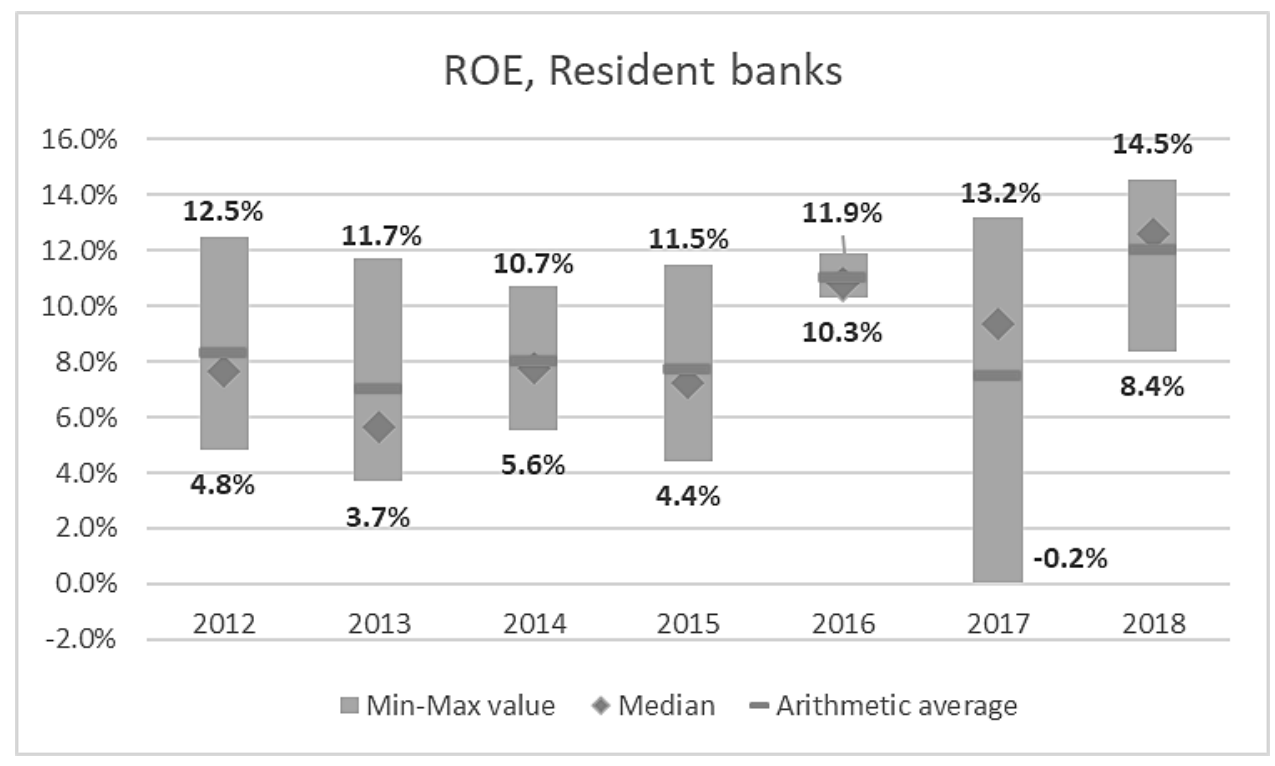

Figure 12 ROE values of the resident bank group (Financial and Capital Market Commission, 2012-2018) (compiled by the authors)

The ROE values of non-resident banks were much more dispersed, ranging from $-43.6 \%$ in 2013 to $+42.8 \%$ in 2016 (see Figure 13).

Positive ROE values for all non-resident banks in Latvia are observed only in 2016.

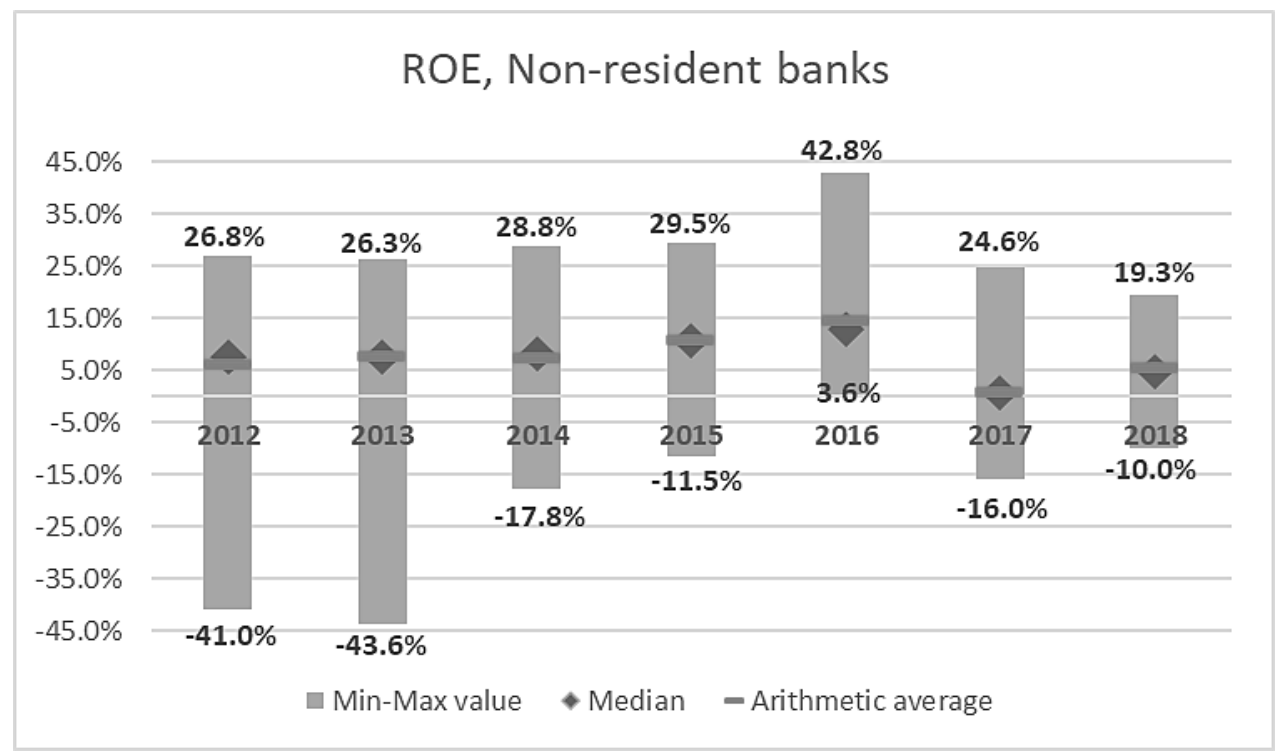

Figure 13 ROE values of the non-resident bank group (Financial and Capital Market Commission, 2021-2018) (compiled by the authors) 
The results obtained show that the ROE values of non-resident banks, similarly as CAR, are more widely dispersed in comparison to resident banks in Latvia, with some nonresident banks constantly demonstrating significant losses in the period of 2012-2018. The only year when all non-resident banks have positive ROE is 2016 - the starting year of financial reform.

Both performance parameters demonstrate the higher volatility of non-resident banking business, which for some non-resident banks is under threat of non-compliance with regulatory requirements.

\section{Impact of total deposit dynamics on resident and non-resident bank profit during the period of 2012-2018}

If we look simultaneously at the dynamics of total deposits and profits before taxes in banks during the period of 2012-2018 and compare the patterns for resident and nonresident banks, we come to two different results (see Figure 14).

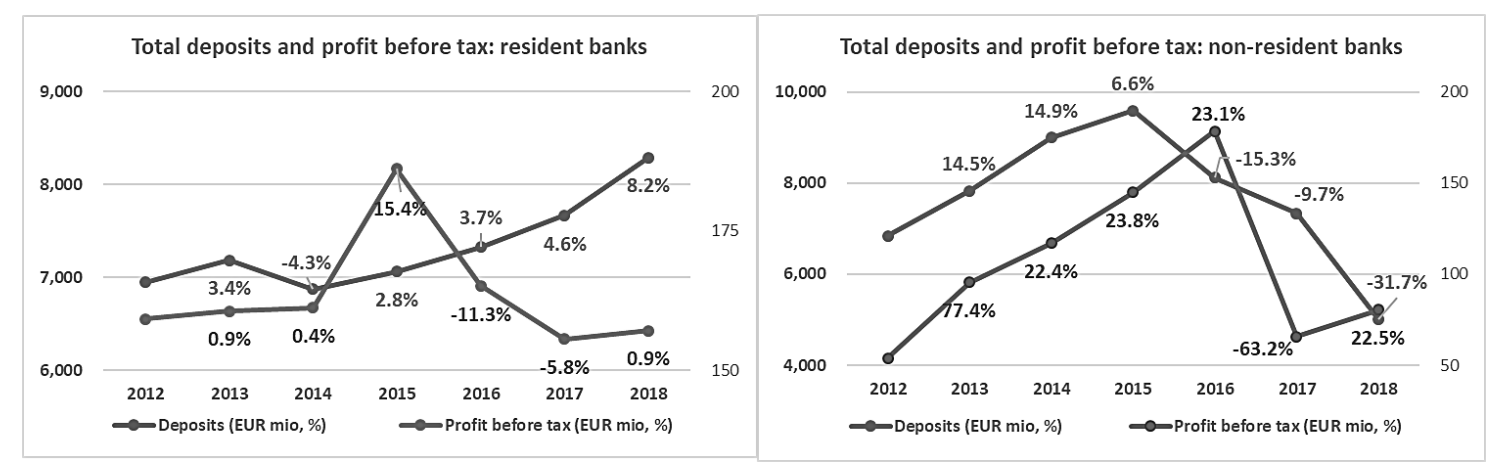

Figure 14 Dynamics of total deposits and profit before tax of resident and nonresident banks, 2012-2018 (EUR million, \%) (Financial and Capital Market Commission, 2012-2018) (compiled by the authors)

For resident banks, with the increase in total deposits, profit before taxes did not change very significantly (with the exception of a sharp peak in 2015). ${ }^{3}$

For the non-resident bank group, profit before taxes experienced a much steeper increase in the period before the start of financial reform, and that correlates with an increase in total deposits, but with the first year of reform implementation, both total deposits and

\footnotetext{
${ }^{3} \mathrm{~A}$ one-off increase in profit in 2015, which exceeded EUR 40 million and affected the entire resident group, was held by Swedbank. In 2016, Swedbank's profit before tax fell by more than EUR 40 million because no more income from loan repayments was received, and the previously created loan provisions were not released (Swedbank JSC, 2016).
} 
profits began to decrease sharply. The dynamics of profit decrease in 2017 were 10 times faster $(63.2 \%$ in 2017) than in resident banks.

If we look at the bank income structure, both the net interest income and net commission income of non-resident banks declined with the outflow of foreign depositors (see Figure 15), but commission income and total profit before tax continued to grow in 2016 and fell with a one-year offset only in 2017. The increase in commission income in 2016, as the deposit portfolio shrank by $15.3 \%$, can be explained by the fact that banks charged high commissions when transferring large cash flows away from the Latvian banking system to foreign customers.

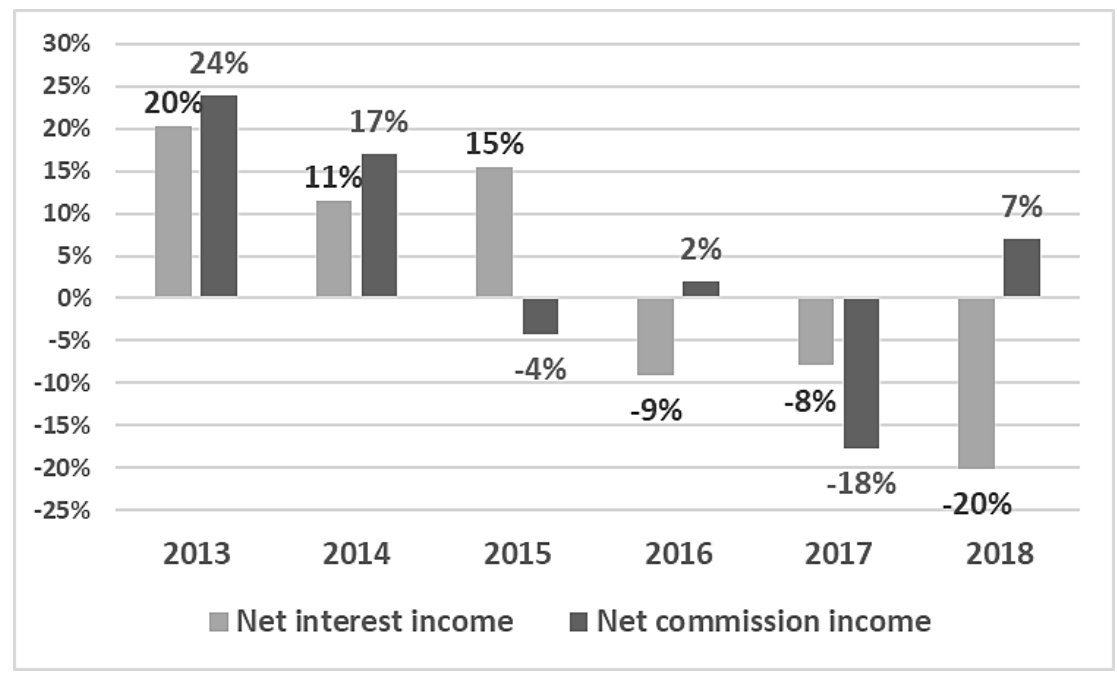

Figure 15 Dynamics of net interest income and net commission income of non-resident banks, 2013-2018 (\%) (Financial and Capital Market Commission, 2012-2018) (compiled by the authors)

The interesting fact is that the non-resident banking group's performance started to recover in 2018 (see Figure 15). Although one year is too short a period of time to draw conclusions, one can note that the positive dynamics coincided with the application of new business strategies by non-resident banks agreed with the FCMC and may be related to the fact that, in general, non-resident banks were starting to adjust to the new market situation.

Our suggestion is that survival and further successful performance of non-resident banks will be essentially determined by refocusing their business strategies in order to maintain and improve their profitability, by developing credit services for local and EU-resident businesses and households, while not fully ceasing to dispose of non-resident deposits.

Non-resident banks should also develop co-operation with other market players by offering syndicated loans to share credit risk and attract high-quality customers and should provide alternative lending products that generate high commission income to offset the 
commission income that has been previously generated by serving high-risk non-resident client transactions.

\section{CONCLUSIONS}

1. The historically formed two banking groups in Latvia (resident and non-resident banks) demonstrated different performance patterns during the period of 20122018: CAR and ROE parameters for non-resident banks were much more dispersed and sometimes approached critical values, which has clearly demonstrated the volatility and riskiness of the non-resident banking business model in Latvia.

2. Therefore, the implementation of the Latvian financial sector reform initiated by the Latvian government and the regulator in 2016 aimed at improving the reputation of the Latvian financial sector and combating ML/TPF has caused a significant outflow of deposits and significantly lowers the performance only of non-resident banks in Latvia.

3. The implementation of the Latvian financial sector reform had a minimal impact on resident bank performance in Latvia.

4. The partial "recovery" of non-resident bank performance at the next stage of financial reform (after 2017) could be an indication that non-resident banks were demonstrating some adaptation to the new business environment without having significant amounts of non-resident deposit inflows.

5. Our suggestion is that survival and further successful performance of non-resident banks in Latvia will be essentially determined by refocusing their business strategies in order to maintain and improve their profitability, by developing credit services for local and EU-resident businesses and households, while not fully ceasing to dispose of non-resident deposits. 


\section{REFERENCES}

1. Bank of Latvia (2014-2019), Statistics, Data, MFI balances and monetary statistics: 03 MFI (with the exception of Bank of Latvia) attracted deposits (data starting from December 2014), available at: https://www.bank.lv/statistika/dati-statistika/mfi-bilances-un-monetarastatistika-k (accessed 22 November 2019).

2. Bank of Latvia (2019), Financial Stability Report, 2018, p. 33, available at: https://www.bank.lv/images/stories/pielikumi/publikacijas/FSP_2018.pdf (accessed 13 October 2019).

3. Basel Committee on Banking Supervision (2011), Basel III: A global regulatory framework for more resilient banks and banking systems, available at: https://www.bis.org/publ/bcbs189.pdf (accessed 25 July 2019).

4. Casu, B., Girardone, C. and Molyneux, P. (2006), Introduction to Banking, Pearson Education Limited, London.

5. Diamond, D. W., Rajan, R. G. (2000), “A Theory of Bank Capital”, The Journal of Finance, Vol. 55, No. 6, pp. 2431-2465, available at: https://faculty.chicagobooth.edu/douglas.diamond/research/papers/bankcapital.pdf (accessed 5 August 2019).

6. Djalilov, K., Piesse, J. (2016), "Determinants of Bank Profitability in Transition Countries: What Matters Most?”, Research in International Business and Finance, Vol. 38(C), pp. 6982, available at: http://eprints.bournemouth.ac.uk/23537/1/Paper\%202016_w_authors_final-3.pdf (accessed 19 August 2019).

7. European Central Bank (2010), Beyond ROE - How to measure bank performance. Appendix to the report on EU banking structures, September 2010, available at: https://www.ecb.europa.eu/pub/pdf/other/beyondroehowtomeasurebankperformance20100 9en.pdf (accessed 21 October 2019).

8. Finance Latvia Association (2012-2018), Data: Industry Data, available at: https://www.financelatvia.eu/nozares-dati/ (accessed 9 August 2019).

9. Financial and Capital Market Commission (2012-2018), Statistics, Credit Institutions, Quarterly Reports, available at: https://www.fktk.lv/statistika/kreditiestades/ceturksnaparskati/ (accessed 22 September 2019).

10. Financial and Capital Market Commission (2019), Change management in Latvian Financial Sector 2016-2019: Review of essential events and statistics, available at: https://www.fktk.lv/wp-content/uploads/2019/06/PREZ_Bankusektora_transform\%C4\%81cija_2016-2019_saites.pdf (accessed 9 August 2019). 
11. Fraisse, H., Lé, M. and Thesmar, D. (2017), "The real effects of bank capital requirements”, European Systemic Risk Board, Working Paper Series, No. 47, pp. 1-43, available at: https://www.esrb.europa.eu/pub/pdf/wp/esrbwp47.en.pdf (accessed 15 August 2019).

12. Hakenes, H., Schnabel, I. (2011), "Bank Size and Risk-Taking under Basel II”, Journal of Banking and Finance, Vol. 35, No. 6, pp. 1436-1449, available at: http://ssrn.com/abstract=700581 (accessed 9 August 2019).

13. Haufler, A., Maier, U. (2016), Regulatory competition in capital standards with selection effects among banks. Munich Discussion Paper No. 2016-5. Department of Economics, University of Munich, available at: https://epub.ub.uni-muenchen.de/27700 (accessed 25 August 2019).

14. Howarth, D., Quaglia, L. (2013), "Banking on Stability: The political economy of new capital requirements in the European Union", Journal of European Integration, Vol. 35, No. 3, pp. 333-346, available at: https://orbilu.uni.lu/bitstream/10993/4555/3/ Howarth\%20and\%20Quaglia\%20for\%20JEI\%20author\%20postprint.pdf (accessed 27 July 2019).

15. Kashyap, A. K., Stein, J. C. (2004), “Cyclical implications of the Basel II capital standards", Economic Perspectives, 1Q, pp. 18-31, available at:

https://scholar.harvard.edu/files/stein/files/cyclical.pdf (accessed 24 August 2019).

16. Luminor bank JSC (2018), Consolidated and bank's annual report for the year ended on 31 December 2017, available at:

https://www.luminor.lt/sites/default/files/documents/luminor-lv-annual-report-2017-lv.pdf (accessed 22 November 2019).

17. Moody's Analytics (2013), Basel III Capital and Liquidity Standards - FAQs, available at: https://www.moodysanalytics.com/-/media/article/2013/2013-18-10-basel-iii-capital-andliquidity-standards-faq.pdf (accessed 17 August 2019).

18. Repullo, R., Suarez, J. (2013), “The procyclical effects of bank capital regulation”, EconPapers, Review of Financial Studies, Vol. 26, No. 2, pp. 452-490, available at: https://www.cemfi.es/ suarez/repullo-suarez09.pdf (accessed 5 August 2019).

19. Rietumu bank JSC (2019), Annual report 2018, available at https://www.rietumu.lv/documents/latvian/ar/ar2018.pdf (accessed 22 November 2019).

20. Swedbank JSC (2016), Consolidated and bank's financial report for the year 2015, available at:

https://www.swedbank.lv/static/pdf/reports/annual/swedbank_gada_finansu_parskats_2015 _LAT.pdf (accessed 18 January 2019). 
21. Swedbank JSC (2017), Consolidated and bank's financial report for the year 2016, available at:

https://www.swedbank.lv/static/pdf/reports/annual/swedbank_gada_finansu_parskats_2016 _LAT.pdf (accessed 18 November 2019). 
Received: 2 April 2020

Accepted for publishing: 16 January 2021

DOI: 10.32025/JBM19007

\section{An analysis of factors affecting the performance of supplier SMEs}

JANIS GERCANS SANDIS BABRIS

\section{ABSTRACT}

Purpose. While the performance of each company is still an important factor in gaining a competitive advantage, in an open economy, the performance of an entire supply chain becomes a crucial factor in the competitiveness of many interconnected companies. In this study, factors that might influence the performance of small and medium-sized enterprises (SMEs) that provide production services for the contracting company are analysed.

Methodology. In this study, the performance data of harvesting ( $n=46)$, timber transportation $(n=23)$, and chipping $(n=3)$ service suppliers in the supply chain of JSC Latvia's State Forests (LVM) are analysed. Based on the supplier's performance data, a group of experts, including two executive directors and five process managers, defined the problems and their root causes. The Ishikawa diagram and 5 Why method were used. The root causes were redefined as hypotheses and regrouped into three groups: 1) workforce factors; 2) managerial factors; 3) contract-term factors. Hypotheses were verified by conducting a survey of suppliers' employees $(n=594)$ and executives $(n=59)$.

Findings. It was found that employees' dissatisfaction with shift work and salaries which do not correspond to work responsibilities, along with suppliers' disregard of the evaluation of employees' skills, complicated work requirements, the lack of training for employees, and the direct manager's insufficient knowledge about the skills needed for employees are the factors that significantly influence voluntary labour turnover and might lead to the leakage of skilled employees from suppliers, causing a performance decline. Meanwhile, there is no significant difference between high and low-performing supplier groups in terms of managerial knowledge, while a limited contract duration does not undermine low-performance suppliers' efforts to improve performance.

Value. In this study, factors that might cause performance problems for supplier SMEs are analysed. In the existing literature, it has been found that voluntary labour turnover might negatively influence the performance of a company (McElroy and Morrow, 2001; Brown et al., 2009; Eady and Nicholls, 2011). This study attempted to assess factors causing voluntary labour turnover 
among other factors. The main contribution of this study is to the literature regarding voluntary labour turnover, supplementing the factors that might cause it.

Keywords: suppliers' performance, root cause, voluntary labour turnover, SMEs

Paper category: research paper

\section{INTRODUCTION}

Competition between single firms is becoming less common as networks of firms compete against each other. In this environment, the disadvantages of an individual firm are often linked to the disadvantages of the network in which the firm operates (Dyer and Singh, 1998). Collaboration has many forms, such as strategic alliances, joint ventures, third-party logistics, short and long-term contracts, partnership sourcing, and retailer-supplier partnerships (Bernhard et al., 2006). These networks provide firms with opportunities to establish mutually beneficial relationships in which to create competitive advantages and impose an obligation to manage performance and overcome obstacles.

Cooperation, compared to a purely competitive approach, makes it possible to extract savings since it gives suppliers the confidence that investments will pay off in the long run (Terpend and Krause, 2015). However, small businesses are, in general, conservative and do not want to overexpose or overextend themselves to certain investments. They limit their spending and commitment and only do what is essential to reduce uncertainty in running their business (Adams et al., 2012). The supplier potentially benefits from collaborating with the buyer if their collective efforts translate into superior products and hence increased market share (Terpend and Krause, 2015). Furthermore, supplier performance strongly influences buyer performance in the short and long run (Parmigiani and Mitchell, 2005). Suppliers that do not achieve performance targets either need to be developed or replaced (Glock et al., 2017), but terminating a contract might not always be possible, as the buyer may not have an alternative supplier (Porteous et al., 2015). In addition, if a supplier underperforms due to a lack of common knowledge, the supplier should be inspired with confidence and supported to increase the company's relative absorptive capacity rather than being replaced (Kim et al., 2015). These aspects point to the importance of suppliers' development and performance improvement activities.

Supplier relationship management encompasses various activities, such as the identification and selection of appropriate suppliers, the evaluation and development of suppliers, and the continuous monitoring of the suppliers' performance (Glock et al., 2017). Generally, cooperative activities such as supplier development and supplier integration are effective, while supplier monitoring does not have a positive influence on supplier performance (Akamp and Müller, 2013). Direct involvement activities, where the buying company internalises a significant amount of the supplier development effort, play a critical role in performance improvement (Krause et al., 2000). In addition to standard 
supplier development practices, such as process efficiency and quality improvement, a buying firm may also consider helping the supplier to develop inter-organisational networks to enhance supplier buying company-specific innovation value (Yana et al., 2017). Buyer and supplier commitment through maintained specificity intentions, operational linkages, and specific investments is likely to foster long-term buyer-supplier relationships. The latter, consequently, improves organisational performance due to knowledge and process-sharing (Adams et al., 2012). This characterises the essentiality of supplier performance management in product and process improvement by development activities and long-term contract relationships.

Performance management is an uninterrupted process of identifying, measuring, and developing the performance of individuals and teams and aligning it with the strategic goals of the organisation (Aguinis, 2009). Buying firms that share information with and require improvements to suppliers are readily able to respond to market demand (Ralston et al., 2015). Service-buying firms, to a greater extent than product-based firms, tend to rely on the competitive pressure of market forces to encourage supplier performance (Krause and Scannell, 2002) since the supplier's most relevant competitors are those with which it shares a buyer (Chatain, 2011). Product-based firms tend to use assessment, incentives, and direct involvement to a greater extent than service firms (Krause and Scannell, 2002). A buying firm should be aware of their suppliers' abilities and limitations to decide when and where supplier development should occur (Lawson et al., 2014).

Accordingly, it is essential to analyse the supplier's performance, identify problems, and search for the root causes. Considering the conservative nature of small businesses (Adams et al., 2012), this study focuses on suppliers belonging to the small and medium-sized enterprise (SME) category. In business literature, little attention has been paid to the identification of performance problems' root causes and suppliers' development activities in addressing them. However, the literature indicates that it is beneficial for managers to take time to identify and understand the root cause of any problem accurately, no matter how large or small the problem may seem (Arnheiter and Greenland, 2008), and to find the root cause before taking action (Finlow-Bates, 1998). Thus, the following research question is put forward: what are the root causes of a supplier's performance problems? The objective of this study is to determine the factors that might cause performance problems for supplier SMEs. The root cause analysis (RCA) concept is applied to achieve the study objective.

In the next section of the study, literature concerning supplier performance management and the RCA of suppliers' performance problems are analysed. In the third section, the research methods are developed and described. Then, in section four, the study results are reported and analysed. In section five, the findings are discussed and suggestions for further research are proposed, and in section six, the article is concluded with the limitations of the study. 


\section{LITERATURE REVIEW}

\section{Definitions}

There are various definitions of RCA in the literature. Latino et al. define RCA as follows: "the establishing of logically complete, evidence-based, tightly coupled chains of factors from the least acceptable consequences to the deepest significant underlying causes" (Latino et al., 2011). Andersen and Fagerhaug define RCA as "a structured investigation that aims to identify the true cause of a problem and actions necessary to eliminate it" (Andersen and Fagerhaug, 2006). The objective of the present study does not include the actions necessary to eliminate the problem causes. Therefore, in the context of this study, RCA is defined as a logically complete and evidence-based investigation that aims to identify the real cause of a problem (Latino et al., 2011; Andersen and Fagerhaug, 2006). A problem is defined as a negative deviation from a performance norm or standard (Latino et al., 2011). While the cause is the reason for the problem that the management has the ability to fix (Lehtinen et al., 2011; Sarkar et al., 2013), it is preferable to explain the causes with numerical values attached to them, and it is better to express them in a negative way (Sarkar et al., 2013). RCA is an efficient method to detect new process improvement opportunities and develop improvement ideas (Lehtinen et al., 2011). Thus, RCA is a proper method for performance problem cause detection before a particular action is taken.

\section{Root cause analysis method}

Latino et al. recommend that we should have a means of collecting data related to events that affect the performance of the stated objectives. Afterward, we must decide on criteria that will initiate the execution of an RCA and decide if RCA is required. The key to successful analysis is to make sure that the data and information to determine the causes of the problem are being studied (Latino et al., 2011). The data must be collected, analysed, and compared in a way to reveal the causes and simplify further analysis (Ishikawa, 1976). An RCA team has to be assembled, and the team must review the problem and determine what data will be needed to determine the root causes. A logic tree can be utilised to evaluate hypotheses and specify root cause verification methods. Then, hypotheses regarding root causes must be verified, determined and grouped according to whether the cause is physical, human, or latent (Latino et al., 2011). Ishikawa proposes the use of a cause-and-effect diagram to illustrate relationships between the cause and the problem (1976). The recommendation is that the causal factors should be grouped into work methods, materials, equipment, and measurement (Ishikawa, 1976). Practitioners tend to use brainstorming, cause-and-effect analysis, and the five whys or the $5 \mathrm{~W}+1 \mathrm{H}$ (who, when, where, why, what, how) methodology to determine the root cause (Reid and SmythRenshaw, 2012). Team members are asked five 'why' questions to determine the root 
cause (Ishikawa, 1976). Various authors have analysed RCA applicability and its pros and cons (Sarkar et al., 2013; Lehtinen et al., 2011; Emery, 2009; Iedema et al., 2008; Arnheiter and Greenland, 2008; Finlow-Bates, 1998; Dobrusskin, 2016; Reid and SmythRenshaw, 2012). In this study, the cause-and-effect diagram is considered to be the most suitable method, and five 'why' questions are used to search for the root cause. The choice of the method is based on its simple use. The use of more sophisticated methods requires the training of the practitioners' expert group and repeated practice to achieve the objective of the RCA. In a further literature review, the factors that might influence the performance of suppliers are analysed.

\section{Workforce performance}

The productivity of the supplier's workers can influence the costs and thus the price of the product or service it provides. The theory of personnel economics predicts that pay based on output will induce workers to supply more output because of incentive effects. The productivity and average effort level of workers increases when moving from a fixed wage to piece-rate pay, and high-skill workers tend to select the piece-rate pay scheme (Lazear, 2000; Eriksson and Villeval, 2008; Franceschelli et al., 2010). Other studies show that workers are insensitive to pay-for-performance exposure regarding working hours, intentions to quit, life, and job satisfaction (Allen et al., 2017). However, intentions to quit and labour turnover might influence a supplier's performance. Studies show that voluntary labour turnover has negative consequences for profitability, productivity, and costs (McElroy and Morrow, 2001), and if the quit rate decreases, the firm's performance increases (Brown et al., 2009). The cost of labour turnover will be highest for those companies whose production needs are complex and quality requirements are demanding (Eady and Nicholls, 2011). However, economic performance depends on many factors that vary according to the type of firm and related circumstances. It would be wise to work at least with a motivated threshold value, specific for a firm or industry, that indicates from which point onwards turnover can be considered as a negative indicator (Glebbeek and Bax, 2004). It is also vital to know who leaves the firm and the type of work. Highperforming workers' turnover has a strong negative impact on firms' return on equity (ROE) and return on assets (ROA), and firms which invest less in human capital would face a more substantial negative impact of high-performer turnover than those that invest more (Kwon and Rupp, 2013). However, the turnover of unskilled workers in a context with low hiring costs and losses in labour productivity has an inverted U-shaped relationship between employee turnover and performance (Siebert and Zubanov, 2009). Previous studies also show that job satisfaction, tenure (Breukelen et al., 2004; Caillier, 2011), earning graduate degrees without career promotion (Benson et al., 2004), coworkers' job embeddedness and job search behaviour (Felps et al., 2009), gender composition in the workplace (Bygren, 2010), employer-provided training (Haines et al., 2010), occupational commitment (Schmidt and Lee, 2008), and emotional exhaustion (Chau et al., 2009) might cause voluntary labour turnover. Thus, voluntary labour turnover 
might influence supplier performance in terms of profitability, productivity, and costs. The influence might be even more significant in SMEs that employ high-skill workers such as forest machine operators. To find out the root causes of high-skill workers' voluntary labour turnover in SMEs, the following hypotheses are put forward:

$\mathrm{H}_{1}$ : voluntary labour turnover is caused by:
a) workers' dissatisfaction with the current shift work
b) disregarding the evaluation of workers' professional skills
c) non-compliance of salaries with work responsibilities
d) complicated work requirements
e) disregarding workers' training
f) managers' lack of knowledge about the skills needed for employees
g) high labour demand
h) low confidence regarding professional skills
i) lack of a premium on salaries for productivity
j) lack of a premium on salaries for the quality of the work
k) lack of desire to improve professional skills
1) high discipline at work

\section{Knowledge of managers}

Considering that leaders must deal with various roles and duties, make sound decisions, solve problems, develop new ideas, and engage with partners and clients (Chan et al., 2017), they need to have extensive knowledge of the functions that are important for the company. Companies might acquire the necessary management knowledge by hiring professionals in a particular field. However, SMEs have limited financial resources to hire knowledgeable professionals for their management functions, such as financial, quality, efficiency, and human resource management. Thus, insufficient expertise in management functions might be the root cause of suppliers' incapability of achieving performance objectives. To find out whether managers of high-performing suppliers have significantly better knowledge in a management function, the following hypotheses are put forward:

$\mathrm{H}_{2}$ : low-performance suppliers' managers do not have sufficient knowledge in:
a) the development of a motivating remuneration system
b) the management of employees' skills
c) the company's financial management
d) the management of a company's efficiency 
e) quality management

$\mathrm{H}_{3}$ : low-performance suppliers' managers have difficulty in attracting professional employees.

Managers are asked self-appraisal questions (Alter, 2002; Shore and Tashchian, 2002) to evaluate their knowledge and test hypotheses.

\section{Collaboration performance}

Cooperation between buyer and supplier might lead to performance improvement, and lack of it could cause problems. Studies show that supply chain partners' intentions to invest in supplier development critically depend on the length of the contract period. Supplier development can be improved by dynamically extending the contract, thus avoiding the risk of being contractually tied for an unnecessarily long period (Worthmann et al., 2016). Moreover, without the assurance of a long-term contract, a supplier is unlikely to make investments that would reduce the cost for one particular buyer and would constitute an unacceptable risk (Terpend and Krause, 2015). The influence of buyer commitment on supplier firm performance depends on which buyer cost reduction strategy is used (Yoon and Moon, 2017). Studies show that shared problem-solving with suppliers harms profitability and flexibility but does not significantly affect financial performance (Brito et al., 2014), and social interaction ties do not directly influence cost reduction (Carey et al., 2011). The buyer's communication process in evaluating the supplier does not ensure improved supplier performance unless the supplier is committed to the buying firm (Prahinski and Benton, 2004). Moreover, Modi and Mabert point out that evaluation and certification efforts are the most crucial supplier development prerequisites before undertaking operational knowledge transfer activities, such as site visits and supplier training (Modi and Mabert, 2007). In addition, the buyer can influence the supplier's commitment through increased efforts in cooperation and commitment (Prahinski and Benton, 2004), and collaborative inter-organisational communication is an essential factor to turn an organisation's efforts into supplier performance improvements (Modi and Mabert, 2007); also, information exchange with suppliers has a significant effect on profitability (Brito et al., 2014). Accordingly, the length of the contract period, its extension conditions, and the commitment of both parties might influence the efforts in performance improvement activities. Additionally, it is argued that a limited contract term might reduce suppliers' efforts to improve their processes and invest in development. A limited contract term is particularly relevant for state-owned enterprises, for which the maximum contract term with suppliers is specified by law. Therefore, the following hypotheses are put forward:

$\mathrm{H}_{4}$ : a contract term limited by a five-year period significantly undermines low-performance suppliers' efforts to:

a) improve efficiency 

b) improve quality
c) make proposals for cooperation improvement
d) invest in workforce development
e) invest in technological development

Given that voluntary labour turnover might negatively influence the performance of different companies (McElroy and Morrow, 2001; Brown et al., 2009; Eady and Nicholls, 2011; Kwon and Rupp, 2013), hypothesis $\mathrm{H}_{1}$ is tested studying 59 suppliers regardless of performance level, and employees are chosen as respondents. Voluntary labour turnover is attributed to 'workforce factors'. However, to assess whether low performance of suppliers is caused by insufficient managerial knowledge (attributed to 'managerial factors', $\mathrm{H}_{2}$ and $\mathrm{H}_{3}$ ) or a limited contract term that undermines low-performance suppliers' efforts (attributed to 'contract-term factors', $\mathrm{H}_{4}$ ), executives of suppliers' companies are chosen as respondents. In summary, the hypotheses derived from the performance-influencing factors are elaborated in the following model.

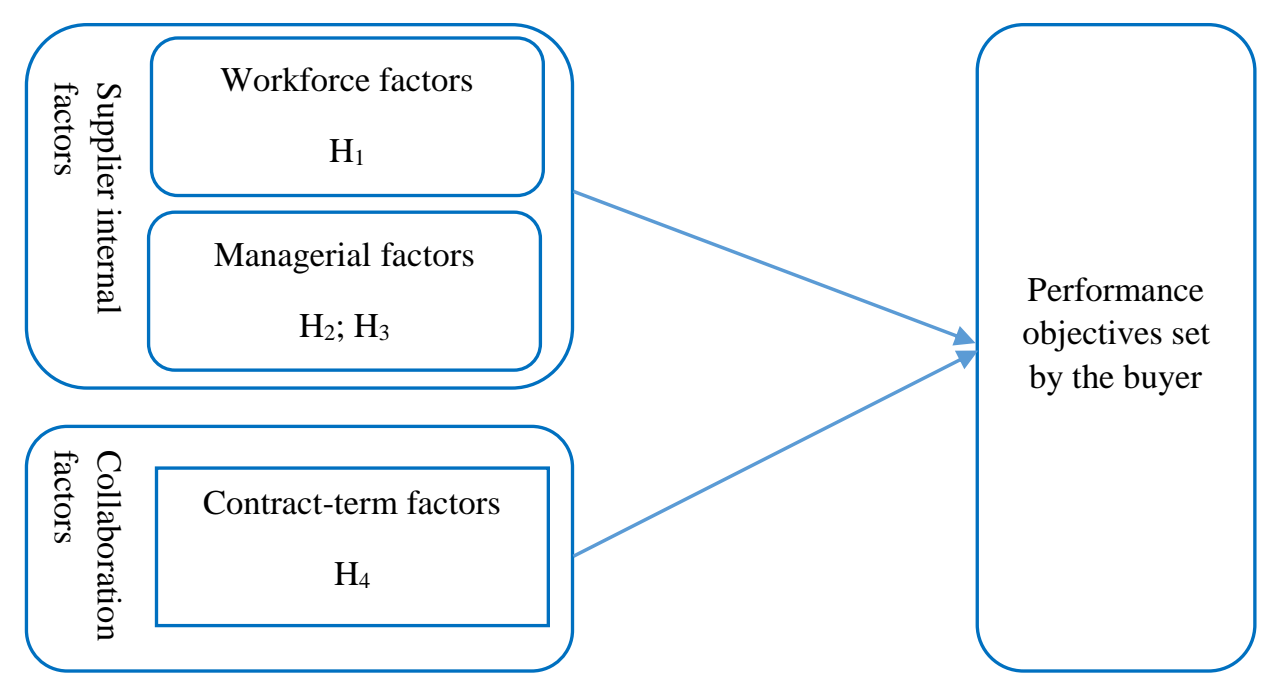

Figure 1 Supplier performance-influencing factors

\section{METHODS}

In this study, the performance data of harvesting $(n=46)$, timber transportation $(n=23)$, and chipping $(n=3)$ service suppliers in the supply chain of JSC Latvia's State Forests (LVM) are analysed. Based on the supplier's performance data, a group of experts, including two executive directors and five process managers, defined the problems and their root causes (Latino et al., 2011; Reid and Smyth-Renshaw, 2012). The Ishikawa diagram and 5Why 
method were used (Ishikawa, 1976). The root causes were redefined as hypotheses and grouped into three groups: 1) workforce factors; 2) managerial factors; 3) contract-term factors. Hypotheses were verified by conducting a survey of suppliers' employees $(n=594)$ and executives $(n=59)$. Likert's 5-point scale is used in the questionnaire for most questions (Appendix 1). Pearson's chi-squared test is used for the analysis of employees' questionnaire data and testing hypothesis $\mathrm{H}_{1}$, and the Mann-Whitney $\mathrm{U}$ test is applied for the analysis of the executives' questionnaire data and testing hypotheses $\mathrm{H}_{2}, \mathrm{H}_{3}$ and $\mathrm{H}_{4}$. The study method is presented in Figure 2.

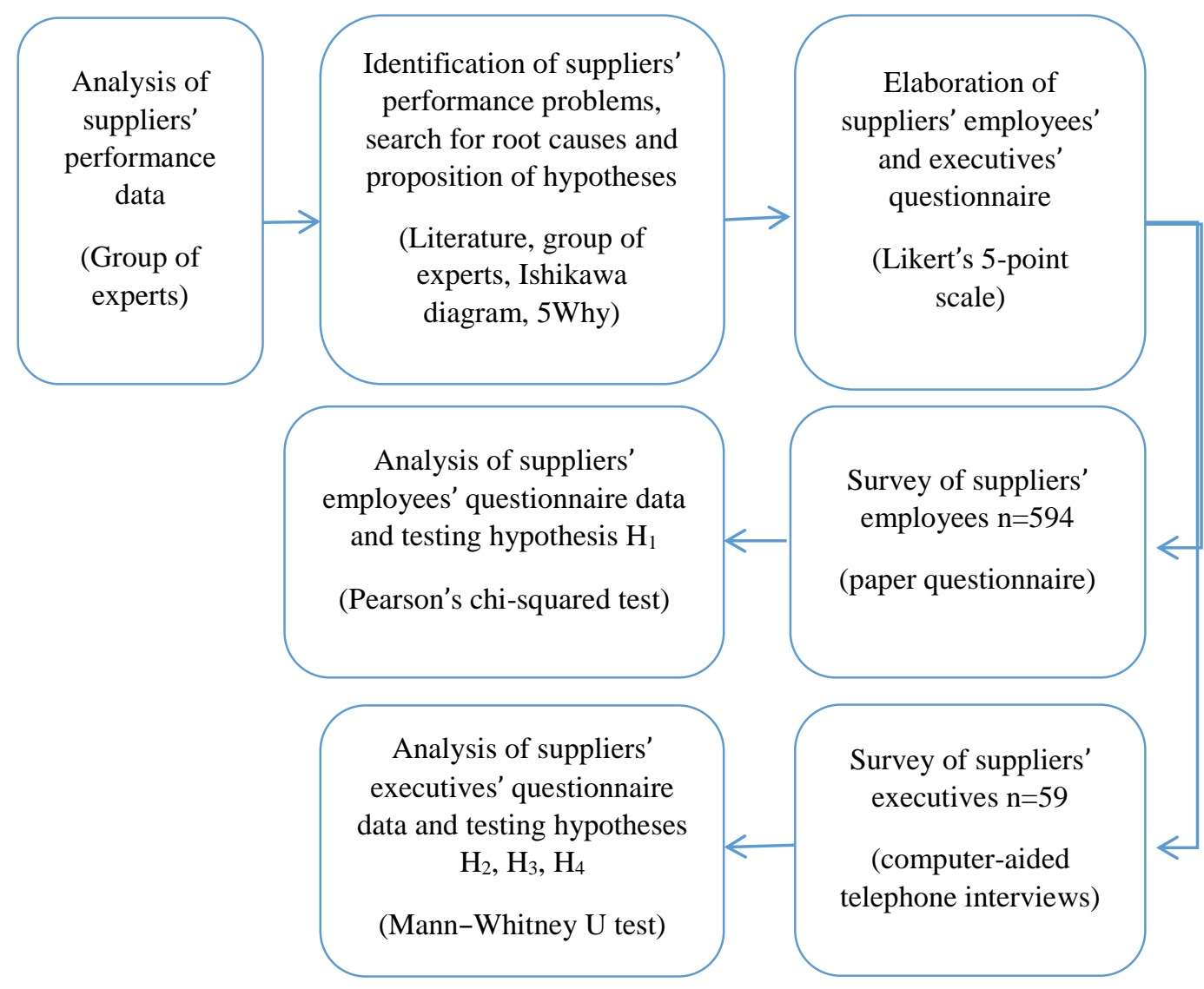

Figure 2 Study method scheme

\section{RESULTS}

The group of experts identified two main performance problems of suppliers: 1) 52\% of suppliers do not achieve the labour productivity objectives set by the buyer; 2) $33 \%$ of suppliers do not achieve quality objectives set by the buyer. The hypotheses derived from 
the root causes of the given performance problems are presented in Appendix 1. A lack of a qualified workforce is one of the root causes of performance problems, as $88 \%$ of executives point out that attracting skilled employees is hard or very hard. Thus, keeping qualified employees in the company is an important task for suppliers' managers.

Employees' dissatisfaction with work might increase voluntary labour turnover and cause performance decline (McElroy and Morrow, 2001; Brown et al., 2009; Eady and Nicholls, 2011). Therefore, employees' questionnaire data is analysed, and hypothesis $H_{1}$ is tested from the perspective of employees who replied that they would continue to work in their current job (1st group, score 4 and 5 on Likert scale, $n=449$ ), employees who have doubts about continuing work (2nd group, 3 on Likert scale, $n=130$ ), and those who will not continue to work (3rd group, 1-2 on Likert scale, $n=15$ ). The results are presented in Table 1.

Table 1

Work continuance/discontinuance correlation with other factors $(n=594)$

\begin{tabular}{|c|c|c|c|c|c|c|}
\hline No. & Factor & $\begin{array}{l}\text { Pearson's } \\
x^{2}\end{array}$ & $\begin{array}{c}p \text { - } \\
\text { value }\end{array}$ & $\begin{array}{c}\text { 1st } \\
\text { group } \\
\text { mean, } \\
(\mathrm{SD})\end{array}$ & $\begin{array}{c}\text { 2nd } \\
\text { group } \\
\text { mean, } \\
(\mathrm{SD})\end{array}$ & $\begin{array}{c}\text { 3rd } \\
\text { group } \\
\text { mean, } \\
(\mathrm{SD})\end{array}$ \\
\hline $\mathrm{H}_{1 \mathrm{a}}$ & $\begin{array}{l}\text { Satisfaction with the current } \\
\text { shift work }\end{array}$ & 80.4 & $<.001$ & $\begin{array}{c}3.8 \\
(0.7) \\
\end{array}$ & $\begin{array}{c}3.3 \\
(0.9) \\
\end{array}$ & $\begin{array}{c}2.8 \\
(1.1) \\
\end{array}$ \\
\hline $\mathrm{H}_{1 \mathrm{~b}}$ & $\begin{array}{l}\text { Evaluation of employees' } \\
\text { professional skills }\end{array}$ & 38.8 & $<.001$ & $\begin{array}{c}3.6 \\
(1.3) \\
\end{array}$ & $\begin{array}{c}3.2 \\
(1.6) \\
\end{array}$ & $\begin{array}{c}2.2 \\
(1.4) \\
\end{array}$ \\
\hline $\mathrm{H}_{1 \mathrm{c}}$ & $\begin{array}{l}\text { The salary corresponds with } \\
\text { the work responsibilities }\end{array}$ & 96.7 & $<.001$ & $\begin{array}{c}3.2 \\
(0.8) \\
\end{array}$ & $\begin{array}{c}2.6 \\
(0.8) \\
\end{array}$ & $\begin{array}{c}2.1 \\
(1.2) \\
\end{array}$ \\
\hline $\mathrm{H}_{1 \mathrm{~d}}$ & $\begin{array}{l}\text { Complication of the work } \\
\text { requirements }\end{array}$ & 25.2 & .001 & $\begin{array}{c}3.2 \\
(0.9) \\
\end{array}$ & $\begin{array}{c}3.5 \\
(0.8) \\
\end{array}$ & $\begin{array}{c}3.7 \\
(1.1) \\
\end{array}$ \\
\hline $\mathrm{H}_{1 \mathrm{e}}$ & $\begin{array}{l}\text { Training to improve } \\
\text { employees' professional } \\
\text { skills }\end{array}$ & 25.5 & .001 & $\begin{array}{c}3.8 \\
(0.8)\end{array}$ & $\begin{array}{c}3.4 \\
(1.0)\end{array}$ & $\begin{array}{c}3.2 \\
(1.0)\end{array}$ \\
\hline $\mathrm{H}_{1 \mathrm{f}}$ & $\begin{array}{l}\text { Direct manager's } \\
\text { knowledge about the skills } \\
\text { needed for employees }\end{array}$ & 18.8 & .016 & $\begin{array}{c}4.0 \\
(0.8)\end{array}$ & $\begin{array}{c}3.8 \\
(0.8)\end{array}$ & $\begin{array}{c}3.3 \\
(1.2)\end{array}$ \\
\hline $\mathrm{H}_{1 \mathrm{~g}}$ & Easy to find another job & 14.5 & .070 & $\begin{array}{l}3.5 \\
(0.9)\end{array}$ & $\begin{array}{c}3.6 \\
(0.8)\end{array}$ & $\begin{array}{c}3.7 \\
(1.0)\end{array}$ \\
\hline $\mathrm{H}_{1 \mathrm{~h}}$ & $\begin{array}{l}\text { Confidence in professional } \\
\text { skills }\end{array}$ & 11.2 & .081 & $\begin{array}{c}3.7 \\
(0.7) \\
\end{array}$ & $\begin{array}{c}3.7 \\
(0.7) \\
\end{array}$ & $\begin{array}{c}4.0 \\
(0.8) \\
\end{array}$ \\
\hline $\mathrm{H}_{1 \mathrm{i}}$ & $\begin{array}{l}\text { Premium on salary for } \\
\text { productivity (nominal data, } \\
\text { Yes or No) }\end{array}$ & 4.5 & .105 & $\begin{array}{c}1.7 \\
(0.4)\end{array}$ & $\begin{array}{c}1.8 \\
(0.4)\end{array}$ & $\begin{array}{c}1.7 \\
(0.5)\end{array}$ \\
\hline $\mathrm{H}_{1 \mathrm{j}}$ & $\begin{array}{l}\text { Desire to improve } \\
\text { professional skills }\end{array}$ & 13.1 & .110 & $\begin{array}{c}3.9 \\
(0.8) \\
\end{array}$ & $\begin{array}{c}3.8 \\
(0.9) \\
\end{array}$ & $\begin{array}{c}3.5 \\
(1.2) \\
\end{array}$ \\
\hline $\mathrm{H}_{1 \mathrm{k}}$ & $\begin{array}{l}\text { Premium on salary for the } \\
\text { quality of the work } \\
\text { (nominal data, Yes or No) }\end{array}$ & 2.5 & .281 & $\begin{array}{l}1.8 \\
(0.4)\end{array}$ & $\begin{array}{l}1.8 \\
(0.4)\end{array}$ & $\begin{array}{c}1.7 \\
(0.5)\end{array}$ \\
\hline
\end{tabular}




\begin{tabular}{clccccc}
\hline $\mathrm{H}_{11}$ & $\begin{array}{l}\text { High discipline at the } \\
\text { current workplace }\end{array}$ & 3.1 & .790 & $\begin{array}{c}4.3 \\
(0.6)\end{array}$ & $\begin{array}{c}4.3 \\
(0.6)\end{array}$ & $\begin{array}{c}4.4 \\
(0.6)\end{array}$ \\
\hline Test for a difference among groups & $\begin{array}{c}\text { Kruskal- } \\
\text { Wallis H }\end{array}$ & $\begin{array}{c}p \text { - } \\
\text { value }\end{array}$ & $\begin{array}{c}\text { 1st } \\
\text { group } \\
\text { mean, } \\
\text { (SD) }\end{array}$ & $\begin{array}{c}\text { 2nd } \\
\text { group } \\
\text { mean, } \\
\text { (SD) }\end{array}$ & $\begin{array}{c}\text { 3rd } \\
\text { group } \\
\text { mean, } \\
\text { (SD) }\end{array}$ \\
\hline $\begin{array}{l}\text { Grouping } \\
\text { variable }\end{array}$ & $\begin{array}{l}\text { To what extent do you want } \\
\text { to continue working in your } \\
\text { current job? }\end{array}$ & 395.2 & $<.001$ & $\begin{array}{c}4.3 \\
(0.5)\end{array}$ & $\begin{array}{c}3.0 \\
(0.0)\end{array}$ & $\begin{array}{c}1.7 \\
(0.5)\end{array}$ \\
\hline
\end{tabular}

Sig. at a level of $p \leq 0.05$

The factors that significantly influence voluntary labour turnover comprise employees' dissatisfaction with shift work and salaries that do not correspond with work responsibilities along with suppliers' disregard of the evaluation of employees' skills, complicated work requirements, lack of training for employees, and the direct manager's

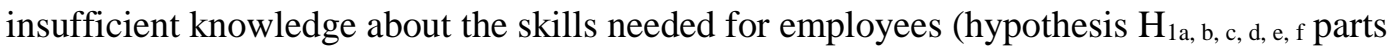
are accepted). This might lead to the leakage of skilled employees from suppliers, causing a supplier's performance decline. As seen in $\mathrm{H}_{\mathrm{hh}}$ (Table 1), confidence in professional skills of employees who will not continue to work is even higher than for those who will continue to work. Moreover, employees who plan to leave their current work are younger, yet at the same time experienced in the forest sector, and have worked for a long time at their current company, 9 and 4 years, respectively (see Appendix 2). High demand for a workforce, which facilitates finding another job, does not have a significant influence on voluntary labour turnover (hypothesis $\mathrm{H}_{1 \mathrm{~g}}$ part is rejected). However, $p$-value 0.07 indicates the trend that in a situation where it is easy to find another job, employees could leave the forest sector, causing workforce ageing problems, since those who plan to leave are younger. Furthermore, employees' confidence in their professional skills, desire to improve skills, and bonuses for the productivity and quality of the work do not significantly influence voluntary labour turnover. Moreover, high discipline at work does not cause employee willingness to leave their current job (hypothesis $\mathrm{H}_{1 \mathrm{~h}, \mathrm{I}, \mathrm{j}, \mathrm{k}, \mathrm{l}}$ parts are rejected).

To identify the root cause of performance problems related to the supplier's management and limited contract term, data from an executive questionnaire is analysed. Suppliers are divided into two groups according to performance data: 1 - the best suppliers $(n=11)$, who meet both quality and labour productivity objectives set by the buyer, and 2 - the rest of the suppliers $(n=48)$, who do not meet the objectives completely. The difference between the two groups of suppliers is analysed, and the results are presented in Table 2. 
Table 2

\section{Suppliers' performance-influencing factors by management and limited contract} term

\begin{tabular}{|c|c|c|c|c|c|c|}
\hline No. & Factor & $\begin{array}{l}\text { Type of } \\
\text { supplier }\end{array}$ & $\begin{array}{c}\text { Mean } \\
\text { rank }\end{array}$ & $\boldsymbol{U}$ & $p$-value & $\begin{array}{c}\text { Type of } \\
\text { supplier } \\
\text { mean, (SD) } \\
\end{array}$ \\
\hline \multirow[b]{2}{*}{$\mathrm{H}_{2 \mathrm{a}}$} & \multirow{2}{*}{$\begin{array}{l}\text { Knowledge in the development } \\
\text { of a motivating remuneration } \\
\text { system }\end{array}$} & 1 & 31.8 & \multirow[b]{2}{*}{244.0} & \multirow[b]{2}{*}{.642} & $4.0(0.4)$ \\
\hline & & 2 & 29.6 & & & $3.9(0.6)$ \\
\hline \multirow{2}{*}{$\mathrm{H}_{2 \mathrm{~b}}$} & \multirow{2}{*}{$\begin{array}{l}\text { Knowledge in the management } \\
\text { of skills for employees }\end{array}$} & 1 & 28.7 & \multirow{2}{*}{250.0} & \multirow{2}{*}{.745} & $3.9(0.5)$ \\
\hline & & 2 & 30.3 & & & $4.0(0.7)$ \\
\hline \multirow{2}{*}{$\mathrm{H}_{2 \mathrm{c}}$} & \multirow{2}{*}{$\begin{array}{l}\text { Knowledge in the company's } \\
\text { financial management }\end{array}$} & 1 & 28.8 & \multirow{2}{*}{250.5} & \multirow{2}{*}{.766} & $3.9(0.7)$ \\
\hline & & 2 & 30.3 & & & $4.0(0.7)$ \\
\hline \multirow{2}{*}{$\mathrm{H}_{2 \mathrm{~d}}$} & \multirow{2}{*}{$\begin{array}{l}\text { Knowledge in the management } \\
\text { of a company's efficiency }\end{array}$} & 1 & 32.2 & \multirow{2}{*}{240.0} & \multirow{2}{*}{.587} & $4.1(0.7)$ \\
\hline & & 2 & 29.5 & & & $4.0(0.6)$ \\
\hline \multirow[b]{2}{*}{$\mathrm{H}_{2 \mathrm{e}}$} & \multirow{2}{*}{$\begin{array}{l}\text { Knowledge in quality } \\
\text { management }\end{array}$} & 1 & 32.4 & \multirow{2}{*}{237.5} & \multirow{2}{*}{.559} & $4.1(0.8)$ \\
\hline & & 2 & 29.5 & & & $3.9(0.7)$ \\
\hline \multirow{2}{*}{$\mathrm{H}_{3}$} & \multirow{2}{*}{$\begin{array}{l}\text { Easy to attract professional } \\
\text { employees }\end{array}$} & 1 & 25.3 & \multirow{2}{*}{212.5} & \multirow{2}{*}{.271} & $1.5(0.5)$ \\
\hline & & 2 & 31.1 & & & $1.8(0.8)$ \\
\hline \multirow[b]{2}{*}{$\mathrm{H}_{4 \mathrm{a}}$} & \multirow{2}{*}{$\begin{array}{l}\text { Suppliers would increase their } \\
\text { efforts for efficiency } \\
\text { enhancement }\end{array}$} & 1 & 24.1 & \multirow[b]{2}{*}{199.0} & \multirow[b]{2}{*}{.163} & $3.8(1.3)$ \\
\hline & & 2 & 31.4 & & & $4.4(0.7)$ \\
\hline \multirow{2}{*}{$\mathrm{H}_{4 b}$} & \multirow{2}{*}{$\begin{array}{l}\text { Suppliers would increase their } \\
\text { efforts for quality improvement }\end{array}$} & 1 & 26.4 & \multirow{2}{*}{224.0} & \multirow{2}{*}{.396} & $4.0(1.2)$ \\
\hline & & 2 & 30.8 & & & $4.3(0.8)$ \\
\hline \multirow[b]{2}{*}{$\mathrm{H}_{4 \mathrm{c}}$} & Suppliers would provide more & 1 & 30.3 & & & $4.0(1.3)$ \\
\hline & $\begin{array}{l}\text { proposals for cooperation } \\
\text { improvement }\end{array}$ & 2 & 29.9 & 260.5 & .942 & $4.2(0.8)$ \\
\hline & Suppliers would invest more in & 1 & 25.0 & & & $4.0(1.2)$ \\
\hline $\mathrm{H}_{4 \mathrm{~d}}$ & workforce development & 2 & 31.2 & 9.0 & .236 & $4.4(0.8)$ \\
\hline & Suppliers would invest more in & 1 & 25.0 & & & $4.1(1.2)$ \\
\hline $\mathrm{H}_{4 \mathrm{e}}$ & technological development & 2 & 31.2 & 20 & .219 & $4.5(0.7)$ \\
\hline & Experience of a supplier in the & 1 & 31.7 & & & $17.5(6.6)$ \\
\hline $\mathrm{C}$ & forest sector & 2 & 29.6 & 245 . & .708 & $16.9(5.6)$ \\
\hline
\end{tabular}

Sig. at a level of $p \leq 0.05$

Both groups of suppliers have similar experiences in the forest sector. There is no significant difference between the two groups of suppliers regarding the executives' selfappraisal of knowledge in management functions and their ability to attract professional employees (hypotheses $\mathrm{H}_{2}$ and $\mathrm{H}_{3}$ are rejected). However, the capability of their companies to achieve performance objectives in the same supply chain are different. Profit per employee for the first supplier group exceeds the second group by $318 \%$ (data from Lursoft database, 2017), and within the five-year period suppliers of the first group increased their share in the buyer's production volume by $3 \%$ annually (data from JSC Latvia's State Forests, 2017). Meanwhile, there is no significant difference between high 
and low-performing supplier groups, i.e., a limited contract duration does not undermine low-performance suppliers' efforts to improve efficiency and quality, provide more proposals for cooperation improvement, and invest more in the workforce and technological development (hypothesis $\mathrm{H}_{4}$ is rejected).

\section{DISCUSSION}

In this study, factors that might influence the performance of SMEs which provide production services for the buying company are analysed. The RCA concept is applied to determine factors that might influence a supplier's performance regarding their capability to achieve labour productivity and quality objectives set by the buying company. In the existing literature, it has been found that voluntary labour turnover might negatively influence the performance of a company (McElroy and Morrow, 2001; Brown et al., 2009; Eady and Nicholls, 2011). First, it has been found that employees' dissatisfaction with shift work and salaries that do not correspond to work responsibilities along with suppliers' disregard of the evaluation of employees' skills, complicated work requirements, lack of training for employees, and the direct manager's insufficient knowledge about the skills needed for employees are the factors that significantly influence voluntary labour turnover and might lead to the leakage of skilled employees from suppliers, causing performance decline. Thus, the findings of this study contribute to the literature regarding voluntary labour turnover, supplementing the factors that might cause it. However, the finding that a lack of training for employees might lead to their departure contradicts the previous study by Haines et al. (2010), where it is argued that training employees might increase the voluntary labour turnover rate. The contradictory findings might arise from the different scope and context of the studies. The study by Haines et al. (2010) includes various industries, while this study is focused on one industry. Since entrepreneurship development tends to be dynamic and requires continuous reassessment (Sauka and Chepurenko, 2017), different voluntary labour turnover-influencing factors might be found in different countries and enterprise settings.

Second, it has been found that an executive's self-appraisal of management knowledge and the ability to attract professional employees is similar for both high and low-performing suppliers. Although executives' knowledge in management is similarly assessed, the capability of their companies to achieve performance objectives is different. Moreover, low-performing suppliers are more confident in their ability to attract professional employees, in the management of skills for employees, and in financial management. This raises the question of how an executive's high self-esteem regarding management knowledge influences the performance of a company. The answer to this question might be explained by the Dunning-Kruger effect. It is argued that unskilled people tend to overestimate their abilities; they have little awareness of their incompetence or lack of expertise (Kruger and Dunning, 1999; Dunning, 2011). Thus, executives of poorly 
performing suppliers may have insufficient knowledge in the management of their companies, which limits the ability to improve the performance and competitiveness of the company. A lack of expertise in management may negatively influence the performance of the buying company (Parmigiani and Mitchell, 2005). Accordingly, the buying company should be aware of their suppliers' abilities and limitations (Lawson et al., 2014) and decide to replace or develop the suppliers (Glock et al., 2017), providing knowledgesharing (Adams et al., 2012). However, a lack of management knowledge among supplier managers was not directly proven in this study. This leaves an open question for further research: Does an executive's knowledge in management influence company performance, and if so, how?

Third, it has been found that limiting the contract period by five years does not limit lowperformance supplier efforts to improve efficiency and quality, provide more proposals for cooperation improvement, and invest more in workforce and technological development. However, the mean values of supplier executives' answers indicate the importance of contract duration. The mean value of high-performing supplier executives' answers to all questions regarding limited contract term influence is 3.98 out of 5 or $80 \%$, while lowperforming suppliers' executives were assessed at the $87 \%$ level. There is a trend that lowperforming suppliers' executives, more than high-performing competitors, consider contract duration to be a limiting factor for greater effort to improve efficiency and quality and invest more in the workforce and technological development. For the buying company, this trend needs to be considered in cases where alternative suppliers are not available. In this study, contracts of suppliers are limited to a five-year collaboration period. To obtain the next contract, a supplier has to participate in the buyer's open tender and compete with other suppliers. All suppliers have equal opportunities to obtain a contract. The buyer does not offer any advantages to suppliers whose performance in the fulfilment of the previous contract was higher than the others. Thus, this is a proper environment to test the influence of limited contract duration. However, such an environment excludes supplier development enhancement by dynamically extending the contract (Worthmann et al., 2016). Nevertheless, further research could investigate how a shorter contract duration, up to five years, might influence supplier efforts to improve buyer-relevant performance; it could also look into what factors are influenced by a short-term contract duration, since we know that without the assurance of a long-term contract, a supplier is unlikely to make investments that would reduce cost for one particular buyer (Terpend and Krause, 2015).

\section{CONCLUSIONS}

1. This study has tried to determine performance-influencing factors that might cause performance problems for supplier SMEs. In carrying out RCA, factors that might affect performance were defined and grouped into three groups: (1) workforce factors, (2) managerial factors, (3) contract-term factors. 
2. Workforce factors include lower-tier factors that might influence the leakage of skilled employees from suppliers, causing a performance decline. According to the literature, voluntary labour turnover might negatively influence the performance of a company (McElroy and Morrow, 2001; Brown et al., 2009; Eady and Nicholls, 2011). This study attempted to reveal the factors that cause voluntary labour turnover. It was found that employees' dissatisfaction with shift work and salaries which do not correspond to work responsibilities, along with suppliers' disregard of the evaluation of employees' skills, complicated work requirements, the lack of training for employees, and the direct manager's insufficient knowledge about the skills needed for employees are the factors that significantly influence voluntary labour turnover and might lead to the leakage of skilled employees from suppliers, causing a performance decline.

3. Meanwhile, managerial factors include lower-tier factors related to an executive's knowledge in management functions and the capability to attract professional employees. There is no significant difference between high and low-performing supplier groups in terms of managerial knowledge and capability to attract professional employees.

4. Finally, contract-term factors were related to the argument that a limited contract period undermines suppliers' efforts to improve buyer-related performance (Terpend and Krause, 2015) and that supplier development might be enhanced by dynamically extending the contract (Worthmann et al., 2016). This study shows that there is no significant difference between high and low-performing supplier groups in this regard, i.e., a limited contract duration does not undermine lowperformance suppliers' efforts to improve performance.

\section{LIMITATIONS}

This study investigated performance-influencing factors of suppliers in the forest industry of Latvia. In other industries or clusters of industries and those in other countries, similar studies may reveal different or supplemental results because of a different context. Forest industry companies included in this study mainly employ manual workers. Therefore, factors influencing the voluntary labour turnover of knowledge workers (Drucker, 1959) might differ from the factors for manual workers. Thus, further research could investigate the difference in factors that influence voluntary labour turnover of knowledge and manual workers.

In this study, a supplier executive's knowledge in management was assessed by selfappraisal questions. Due to the Dunning-Kruger effect (Kruger and Dunning, 1999; Dunning, 2011), the influence of an executive's management knowledge on the performance of a company might be different using another knowledge assessment method. 
The influence of contract duration on supplier efforts to improve performance and invest in development was studied in a supply chain where the buying company does not extend contracts with suppliers dynamically, instead allowing them to compete for the next contract, regardless of the performance in the fulfilment of the previous contract.

Therefore, the influence of contract duration might be different from cases where the buying company extends contracts dynamically, thus enhancing the development of the supplier (Worthmann et al., 2016). 


\section{Appendix 1}

\section{Suppliers' performance problems, their root causes and verification questions}

P1 $-52 \%$ of suppliers do not achieve labour productivity objectives set by the buyer.

P2 $-33 \%$ of suppliers do not achieve quality objectives set by the buyer.

\begin{tabular}{|c|c|c|c|c|c|}
\hline Problem & $\begin{array}{c}\text { Root cause defined } \\
\text { by experts }\end{array}$ & Hypothesis & $\begin{array}{c}\text { Question for testing the } \\
\text { hypothesis }\end{array}$ & Respondent & $\begin{array}{l}\text { Factor } \\
\text { group }\end{array}$ \\
\hline $\mathrm{P} 1 ; \mathrm{P} 2$ & $\begin{array}{l}\text { C1-Exhausting shift } \\
\text { work }\end{array}$ & $\mathrm{H}_{1 \mathrm{a}}$ & $\begin{array}{l}\text { How satisfied are you with } \\
\text { the current shift work? }\end{array}$ & Employee & \multirow{12}{*}{$\begin{array}{l}\text { Workforce } \\
\text { factors }\end{array}$} \\
\hline $\mathrm{P} 1 ; \mathrm{P} 2$ & $\begin{array}{l}\text { C2-Non-evaluation } \\
\text { of employees' skills }\end{array}$ & $\mathrm{H}_{1 \mathrm{~b}}$ & $\begin{array}{l}\text { How often does the } \\
\text { company you work for } \\
\text { evaluate your professional } \\
\text { skills? }\end{array}$ & Employee & \\
\hline $\mathrm{P} 1 ; \mathrm{P} 2$ & $\begin{array}{l}\text { C3-Non-motivating } \\
\text { pay }\end{array}$ & $\mathrm{H}_{1 \mathrm{c}}$ & $\begin{array}{l}\text { To what extent does the } \\
\text { salary correspond with your } \\
\text { work responsibilities? }\end{array}$ & Employee & \\
\hline $\mathrm{P} 1 ; \mathrm{P} 2$ & $\begin{array}{l}\text { C4-Complicated } \\
\text { work requirements }\end{array}$ & $\mathrm{H}_{1 \mathrm{~d}}$ & $\begin{array}{l}\text { How complicated are the } \\
\text { requirements of the current } \\
\text { work? }\end{array}$ & Employee & \\
\hline \multirow{2}{*}{$\mathrm{P} 1 ; \mathrm{P} 2$} & \multirow{2}{*}{$\begin{array}{l}\text { C6-Non-training of } \\
\text { employees }\end{array}$} & $\mathrm{H}_{1 \mathrm{e}}$ & $\begin{array}{l}\text { How sufficient is the } \\
\text { training that the company } \\
\text { provides for you? }\end{array}$ & Employee & \\
\hline & & $\mathrm{H}_{1 \mathrm{k}}$ & $\begin{array}{l}\text { Assess your desire to } \\
\text { improve your professional } \\
\text { skills. }\end{array}$ & Employee & \\
\hline $\mathrm{P} 1 ; \mathrm{P} 2$ & $\begin{array}{l}\text { C7-Direct managers } \\
\text { lack knowledge } \\
\text { about the skills } \\
\text { needed for } \\
\text { employees }\end{array}$ & $\mathrm{H}_{1 \mathrm{f}}$ & $\begin{array}{l}\text { How good is your direct } \\
\text { manager's knowledge } \\
\text { about the skills you need } \\
\text { for your profession? }\end{array}$ & Employee & \\
\hline $\mathrm{P} 1 ; \mathrm{P} 2$ & $\begin{array}{l}\text { C8-High demand } \\
\text { for a workforce in } \\
\text { competing sectors }\end{array}$ & $\mathrm{H}_{1 \mathrm{~g}}$ & $\begin{array}{l}\text { How easy would it be for } \\
\text { you to find another job? }\end{array}$ & Employee & \\
\hline $\mathrm{P} 1 ; \mathrm{P} 2$ & $\begin{array}{l}\text { C9-Insufficient } \\
\text { skills for employees }\end{array}$ & $\mathrm{H}_{1 \mathrm{~h}}$ & $\begin{array}{l}\text { How do you personally } \\
\text { evaluate your professional } \\
\text { skills compared to the } \\
\text { average level in your } \\
\text { profession? }\end{array}$ & Employee & \\
\hline $\mathrm{P} 1$ & $\begin{array}{l}\text { C10-Employee pay } \\
\text { is not dependent on } \\
\text { productivity }\end{array}$ & $\mathrm{H}_{1 \mathrm{i}}$ & $\begin{array}{l}\text { Are you receiving a } \\
\text { premium on wages for } \\
\text { labour productivity? } \\
\text { (Yes/No) }\end{array}$ & Employee & \\
\hline $\mathrm{P} 2$ & $\begin{array}{l}\text { C11-Employee pay } \\
\text { is not dependent on } \\
\text { quality }\end{array}$ & $\mathrm{H}_{1 \mathrm{j}}$ & $\begin{array}{l}\text { Are you receiving a } \\
\text { premium on wages for the } \\
\text { quality of work? (Yes/No) }\end{array}$ & Employee & \\
\hline $\mathrm{P} 1 ; \mathrm{P} 2$ & $\begin{array}{l}\text { C12-High job- } \\
\text { enforcement } \\
\text { discipline }\end{array}$ & $\mathrm{H}_{11}$ & $\begin{array}{l}\text { How high is the discipline } \\
\text { in your current work? }\end{array}$ & Employee & \\
\hline
\end{tabular}


(continued)

\begin{tabular}{|c|c|c|c|c|c|}
\hline $\mathrm{P} 1 ; \mathrm{P} 2$ & $\begin{array}{l}\text { C13-Low employee } \\
\text { motivation to work in } \\
\text { the current job }\end{array}$ & $\begin{array}{l}\text { Grouping } \\
\text { variable }\end{array}$ & $\begin{array}{l}\text { To what extent do you want } \\
\text { to continue working in your } \\
\text { current job? }\end{array}$ & Employee & \\
\hline P1; P2 & $\begin{array}{l}\text { C14-Managers lack } \\
\text { knowledge in the } \\
\text { development of a } \\
\text { motivating } \\
\text { remuneration system }\end{array}$ & $\mathrm{H}_{2 \mathrm{a}}$ & $\begin{array}{l}\text { Assess your knowledge in } \\
\text { the development of a } \\
\text { motivating remuneration } \\
\text { system. }\end{array}$ & Executive & \\
\hline $\mathrm{P} 1 ; \mathrm{P} 2$ & $\begin{array}{l}\text { C15-Managers have } \\
\text { no skills management } \\
\text { knowledge }\end{array}$ & $\mathrm{H}_{2 b}$ & $\begin{array}{l}\text { Assess your knowledge in } \\
\text { the management of skills for } \\
\text { employees. }\end{array}$ & Executive & \\
\hline P1; P2 & $\begin{array}{l}\text { C16-Managers lack } \\
\text { financial } \\
\text { management } \\
\text { knowledge }\end{array}$ & $\mathrm{H}_{2 \mathrm{c}}$ & $\begin{array}{l}\text { Assess your knowledge in } \\
\text { financial management. }\end{array}$ & Executive & $\begin{array}{l}\text { Managerial } \\
\text { factors }\end{array}$ \\
\hline $\mathrm{P} 1$ & $\begin{array}{l}\text { C17-Managers have } \\
\text { no efficiency } \\
\text { management } \\
\text { knowledge }\end{array}$ & $\mathrm{H}_{2 \mathrm{~d}}$ & $\begin{array}{l}\text { Assess your knowledge in } \\
\text { the management of a } \\
\text { company's efficiency. }\end{array}$ & Executive & \\
\hline $\mathrm{P} 2$ & $\begin{array}{l}\text { C18-Managers lack } \\
\text { quality management } \\
\text { knowledge }\end{array}$ & $\mathrm{H}_{2 \mathrm{e}}$ & $\begin{array}{l}\text { Assess your knowledge in } \\
\text { quality management. }\end{array}$ & Executive & \\
\hline $\mathrm{P} 1 ; \mathrm{P} 2$ & $\begin{array}{l}\text { C19-Lack of } \\
\text { qualified employees }\end{array}$ & $\mathrm{H}_{3}$ & $\begin{array}{l}\text { How easy is it for you to } \\
\text { attract qualified employees? }\end{array}$ & Executive & \\
\hline \multirow{5}{*}{$\mathrm{P} 1 ; \mathrm{P} 2$} & \multirow{5}{*}{$\begin{array}{l}\text { C20-Limited contract } \\
\text { period negatively } \\
\text { influences suppliers' } \\
\text { efforts }\end{array}$} & $\mathrm{H}_{4 \mathrm{a}}$ & $\begin{array}{l}\text { If a service contract was not } \\
\text { limited by a five-year period, } \\
\text { how much would it affect the } \\
\text { following efforts: } \\
\text { 1)suppliers would increase } \\
\text { their efforts in efficiency } \\
\text { enhancement }\end{array}$ & Executive & \multirow{5}{*}{$\begin{array}{l}\text { Contract- } \\
\text { term } \\
\text { factors }\end{array}$} \\
\hline & & $\mathrm{H}_{4 \mathrm{~b}}$ & $\begin{array}{l}\text { 2)suppliers would increase } \\
\text { their efforts in quality } \\
\text { improvement }\end{array}$ & Executive & \\
\hline & & $\mathrm{H}_{4 \mathrm{c}}$ & $\begin{array}{l}\text { 3)suppliers would provide } \\
\text { more proposals for } \\
\text { cooperation improvement }\end{array}$ & Executive & \\
\hline & & $\mathrm{H}_{4 \mathrm{~d}}$ & $\begin{array}{l}\text { 4)suppliers would invest } \\
\text { more in workforce } \\
\text { development }\end{array}$ & Executive & \\
\hline & & $\mathrm{H}_{4 \mathrm{e}}$ & $\begin{array}{l}\text { 5)suppliers would invest } \\
\text { more in technology } \\
\text { development }\end{array}$ & Executive & \\
\hline
\end{tabular}

5-point scale answers, except for C10 and C11 


\section{Appendix 2}

Mean values of suppliers' employee age and work experience in the forest sector and at the current company

\begin{tabular}{lccc}
\hline $\begin{array}{c}\text { Work } \\
\text { continuance/discontinua } \\
\text { nce }\end{array}$ & Age, years & $\begin{array}{c}\text { Work experience in } \\
\text { the forest sector, years }\end{array}$ & $\begin{array}{c}\text { Work experience at the } \\
\text { current company, years }\end{array}$ \\
\hline Will not continue to work & 34 & 9 & 4 \\
& $(n=15)$ & $(n=15)$ & $(n=15)$ \\
$(S D 7.2)$ & $(S D 5.7)$ & 6 \\
\hline Doubts about continuing & 41 & 14 & $(S D) .6)$ \\
work & $(n=127)$ & $(n=127)$ & $(S=125)$ \\
& $(S D 10.1)$ & $(S D 8.7)$ & 6 \\
Will continue to work & 41 & 13 & $(n=445)$ \\
& $(n=447)$ & $(n=446)$ & $(S D 4.9)$ \\
\hline
\end{tabular}




\section{REFERENCES}

1. Adams, J. H., Khoja, F. M. and Kauffman, R. (2012), “An empirical study of buyersupplier relationships within small business organizations”, Journal of Small Business Management, Vol. 50, No. 1, pp. 20-40.

2. Aguinis, H. (2009), Performance Management, second edition, Pearson Education, Inc., Upper Saddle River, New Jersey, ISBN 0-13-814691-8.

3. Akamp, M., Müller, M. (2013), "Supplier management in developing countries", Journal of Cleaner Production, Vol. 56, pp. 54-62.

4. Allen, T., Whittaker, W. and Sutton, M. (2017), "Does the proportion of pay linked to performance affect the job satisfaction of general practitioners?", Social Science and Medicine, Vol. 173, pp. 9-17.

5. Alter, J. B. (2002), "Self-appraisal and pedagogical practice: performance-based assessment approaches", Dance Research Journal, Vol. 34, No. 2, pp. 79-95.

6. Andersen, B., Fagerhaug, T. (2006), Root Cause Analysis: Simplified Tools and Techniques. American Society for Quality, Quality Press, Milwaukee, ISBN-13: 978-087389-692-4.

7. Angerhofer, B. J., Angelides, M. C. (2006), “A model and a performance measurement system for collaborative supply chains”, Decision Support Systems, Vol. 42, No. 1, pp. 283-301.

8. Arnheiter, E. D., Greenland, J. E. (2008), "Looking for root cause: a comparative analysis", The TQM Journal, Vol. 20, No. 1, pp. 18-30.

9. Benson, G. S., Finegold, D. and Mohrman, S. A. (2004), "You paid for the skills, now keep them: tuition reimbursement and voluntary turnover", The Academy of Management Journal, Vol. 47, No. 3, pp. 315-331.

10. Breukelen, W., Vlist, R. and Steensma, H. (2004), "Voluntary employee turnover: combining variables from the "traditional" turnover literature with the theory of planned behavior”, Journal of Organizational Behavior, Vol. 25, No. 7, pp. 893-914.

11. Brito, L. A. L., Brito, E. P. Z. and Hashiba, L. H. (2014), "What type of cooperation with suppliers and customers leads to superior performance?", Journal of Business Research, Vol. 67, No. 5, pp. 952-959.

12. Brown, S., Garino, G. and Martin, C. (2009), "Firm performance and labour turnover: evidence from the 2004 workplace employee relations survey", Economic Modelling, Vol. 26, No. 3, pp. 689-695. 
13. Bygren, M. (2010), “The gender composition of workplaces and men's and women's turnover", European Sociological Review, Vol. 26, No. 2, pp. 193-202.

14. Caillier, J. G. (2011), "I want to quit: a closer look at factors that contribute to the turnover intentions of state government employees", State and Local Government Review, Vol. 43, No. 2, pp. 110-122.

15. Carey, S., Lawson, B. and Krause, D. R. (2011), "Social capital configuration, legal bonds and performance in buyer-supplier relationships", Journal of Operations Management, Vol. 29, No. 4, pp. 277-288.

16. Chan, T., Wang, I. and Ybarra, O. (2017), "Leading and managing the workplace: the role of executive functions", Academy of Management Perspectives, Vol. 35, No. 1, AMP2017-0215.R3.

17. Chatain, O. (2010), "Value creation, competition, and performance in buyer-supplier relationships", Strategic Management Journal, Vol. 32, No. 1, pp. 76-102.

18. Chau, S. L., Dahling, J. J., Levy, P. E. and Diefendorff, J. M. (2009), “A predictive study of emotional labor and turnover", Journal of Organizational Behavior, Vol. 30, No. 8, pp. 1151-1163.

19. Dobrusskin, C. (2016), "On the identification of contradictions using cause effect chain analysis", Procedia CIRP, Vol. 39, pp. 221-224.

20. Drucker, P. F. (1959), Landmarks of Tomorrow, Harper and Row, New York.

21. Dunning, D. (2011), “The Dunning-Kruger effect: on being ignorant of one's own ignorance", Advances in Experimental Social Psychology, Vol. 44, pp. 247-296, ISSN 0065-2601.

22. Dyer, J. H., Singh, H. (1998), "The relational view: cooperative strategy and sources of interorganizational competitive advantage", The Academy of Management Review, Vol. 23, No. 4, pp. 660-679.

23. Eady, J. A., Nicholls, M. G. (2011), "Reducing workforce turnover in Asian factories using a mixed-mode modelling approach", The Journal of the Operational Research Society, Vol. 62, No. 4, pp. 651-661.

24. Emery, C. R. (2009), “A cause-effect-cause model for sustaining cross-functional integration”, Business Process Management Journal, Vol. 15, No. 1, pp. 93-108.

25. Eriksson, T., Villeval, M. C. (2008), "Performance-pay, sorting and social motivation", Journal of Economic Behavior and Organization, Vol. 68, No. 2, pp. 412-421. 
26. Felps, W., Mitchell, T. R., Herman, D. R., Lee, T. W., Holtom, B. C. and Harman, W. S. (2009), "Turnover contagion: how coworkers' job embeddedness and job search behaviors influence quitting”, The Academy of Management Journal, Vol. 52, No. 3, pp. 545-561.

27. Finlow-Bates, T. (1998), "The root cause myth”, The TQM Magazine, Vol. 10, No. 1, pp. 10-15.

28. Franceschelli, I., Galiani, S. and Gulmez, E. (2010), "Performance pay and productivity of low- and high-ability workers”, Labour Economics, Vol. 17, No. 2, pp. 317-322.

29. Glebbeek, A. C., Bax, E. H. (2004), "Is high employee turnover really harmful? An empirical test using company records", The Academy of Management Journal, Vol. 47, No. 2, pp. 277-286.

30. Glock, C. H., Grosse, E. H. and Ries, J. M. (2017), "Decision support models for supplier development: systematic literature review and research agenda", International Journal of Production Economics, Vol. 193, pp. 798-812.

31. Haines III, V. Y., Jalette, P. and Larose, K. (2010), "The influence of human resource management practices on employee voluntary turnover rates in the Canadian nongovernmental sector", ILR Review, Vol. 63, No. 2, pp. 228-246.

32. Iedema, R., Jorm, C. and Braithwaite, J. (2008), "Managing the scope and impact of root cause analysis recommendations", Journal of Health Organization and Management, Vol. 22, No. 6, pp. 569-585.

33. Ishikawa, K. (1976), Guide to Quality Control, Asian Productivity Organization, Hong Kong.

34. Kim, H., Hur, D. and Schoenherr, T. (2015), "When buyer-driven knowledge transfer activities really work: a motivation-opportunity-ability perspective", Journal of Supply Chain Management, Vol. 51, No. 3, pp. 33-60.

35. Krause, D. R., Scannell, T. V. (2002), "Supplier development practices: product-and service-based industry comparisons", Journal of Supply Chain Management, Vol. 38, No. 1, pp. 13-21.

36. Krause, D. R., Scannell, T. V. and Calantone, R. J. (2000), “A structural analysis of the effectiveness of buying firms' strategies to improve supplier performance", Decision Sciences, Vol. 31, No. 1, pp. 33-55.

37. Kruger, J., Dunning, D. (1999), "Unskilled and unaware of it: how difficulties in recognizing one's own incompetence lead to inflated self-assessments", Journal of Personality and Social Psychology, Vol. 77, No. 6, pp. 1121-1134. 
38. Kwon, K., Rupp, D. E. (2013), "High-performer turnover and firm performance: the moderating role of human capital investment and firm reputation", Journal of Organizational Behavior, Vol. 34, No. 1, pp. 129-150.

39. Latino, R. J., Latino, K. C. and Latino, M. A. (2011), Root Cause Analysis: Improving Performance for Bottom-Line Results, fourth edition. CRC Press, Boca Raton, ISBN-13: 978-1-4398-5127-2.

40. Lawson, B., Krause, D. R. and Potter, A. (2014), "Improving supplier new product development performance: the role of supplier development", The Journal of Product Innovation Management, Vol. 32, No. 5, pp. 777-792.

41. Lazear, E. P. (2000), "Performance pay and productivity", The American Economic Review, Vol. 90, No. 5, pp. 1346-1361.

42. Lehtinen, T. O. A., Mäntylä, M. V. and Vanhanen, J. (2011), "Development and evaluation of a lightweight root cause analysis method (ARCA method) - field studies at four software companies", Information and Software Technology, Vol. 53, No. 10, pp. 10451061.

43. McElroy, J. C., Morrow, P. C. (2001), “Turnover and organizational performance: a comparative analysis of the effects of voluntary, involuntary, and reduction-in-force turnover", Journal of Applied Psychology, Vol. 86, No. 6, pp. 1294-1299.

44. Modi, S. B., Mabert, V. A. (2007), "Supplier development: improving supplier performance through knowledge transfer", Journal of Operations Management, Vol. 25, No. 1, pp. 42-64.

45. Parmigiani, A., Mitchell, W. (2005), "How buyers shape supplier performance: can governance skills substitute for technical expertise in managing outsourcing relationships?", Academy of Management Annual Meeting Proceedings, C1 - C6, p. 6.

46. Porteous, A. H., Rammohan, S. V. and Lee, H. L. (2015), “Carrots or sticks? Improving social and environmental compliance at suppliers through incentives and penalties", Production and Operations Management, Vol. 24, No. 9, pp. 1402-1413.

47. Prahinski, C., Benton, W. C. (2004), "Supplier evaluations: communication strategies to improve supplier performance", Journal of Operations Management, Vol. 22, No. 1, pp. 39-62.

48. Ralston, P. M., Blackhurst, J., Cantor, D. E. and Crum, M. R. (2015), “A structureconduct-performance perspective of how strategic supply chain integration affects firm performance", Journal of Supply Chain Management, Vol. 51, No. 2, pp. 47-64.

49. Reid, I., Smyth-Renshaw, J. (2012), "Exploring the fundamentals of root cause analysis: are we asking the right questions in defining the problem?", Quality and Reliability Engineering International, Vol. 28, No. 5, pp. 535-545. 
50. Sarkar, S. A., Mukhopadhyay, A. R. and Ghosh, S. K. (2013), "Root cause analysis, lean six sigma and test of hypothesis", The TQM Journal, Vol. 25, No. 2, pp. 170-185.

51. Sauka, A., Chepurenko A. (2017), Entrepreneurship in Transition Economies: Diversity, Trends, and Perspectives, Springer International Publishing AG, Basel, ISBN 978-3-31957342-7.

52. Schmidt, J. A., Lee, K. (2008), "Voluntary retirement and organizational turnover intentions: the differential associations with work and non-work commitment constructs", Journal of Business and Psychology, Vol. 22, No. 4, pp. 297-309.

53. Shore, T. H., Tashchian, A. (2002), “Accountability forces in performance appraisal: effects of self-appraisal information, normative information, and task performance", Journal of Business and Psychology, Vol. 17, No. 2, pp. 261-274.

54. Siebert, S., Zubanov, N. (2009), "Searching for the optimal level of employee turnover: a study of a large U.K. retail organization", The Academy of Management Journal, Vol. 52, No. 2, pp. 294-313.

55. Terpend, R., Krause, D. R. (2015), “Competition or cooperation? Promoting supplier performance with incentives under varying conditions of dependence", Journal of Supply Chain Management, Vol. 51, No. 4, pp. 29-53.

56. Worthmann, K., Braun, P., Proch, M., Schlüchtermann, J. and Pannek, J. (2016), “On contractual periods in supplier development”, IFAC-PapersOnLine, Vol. 49, No. 2, pp. 6065 .

57. Yana, T., Yang, S. and Dooley, K. (2017), “A theory of supplier network-based innovation value”, Journal of Purchasing and Supply Management, Vol. 23, No. 3, pp. 153-162.

58. Yoon, J., Moon, J. (2017), “The moderating effect of buyer purchasing strategy on the relationship between supplier transaction-specific investment and supplier firm performance", Journal of Business Research, available at: https://etarjome.com/storage/panel/fileuploads/2019-07-20/1563610972_E12235-e-tarjome.pdf (accessed 20 September 2017). 


\section{Authors}

\section{Dr Sandis Babris}

BA School of Business and Finance, Riga, Latvia

Assistant professor at BA School of Business and Finance, plant director at Brabantia Latvia SIA, former guest lecturer and assistant professor at the University of Latvia, former $\mathrm{COO} / \mathrm{CFO}$ at Primekss Group.

E-mail: sandis.babris@icloud.com

\section{Janis Gercans}

BA School of Business and Finance, Riga, Latvia

Doctoral student in business management, head of production quality at JSC Latvia's State Forests, guest lecturer at Latvia University of Life Sciences and Technologies.

E-mail: j.gercans@me.com

\section{Dr Ivars Godmanis}

RISEBA University of Applied Sciences, Riga, Latvia

Assistant professor at RISEBA. Ivars Godmanis is a Latvian politician, from 2009-2013 a member of the European Parliament. Godmanis was the first Prime Minister of Latvia after the restoration of Latvian independence (from 1990 until 1993) as well as from 2007 until 2009. In 1995 Godmanis was awarded the Order of the Three Stars and later appointed as the Finance Minister and the Minister of the Interior in 2006. Godmanis is also known as the president of JSC "Latvijas Krājbanka" and vice president of JSC "SWH Riga". His main research interests are international banking and the financial market.

E-mail: Ivars.godmanis8@gmail.com

\section{Linda Jekabsone}

BA School of Business and Finance, Riga, Latvia

Master's student. Professional bachelor's degree in electrical engineering sciences from Riga Technical University, Latvia. Currently studying towards the Master's Degree in 
Cyber Security Management at BA School of Business and Finance in Riga, Latvia. Professional work has been linked to the ICT field for more than 9 years.

E-mail: linda.anspoka@gmail.com

\section{Zita Lavrinovica}

BA School of Business and Finance, Riga, Latvia

Master's student. Bachelor's Degree in Air Traffic Management. ISACA member since 2019. In the future, possible affiliation with the education field. Six years of experience as a physical security specialist in the National Armed Forces of the Republic of Latvia. In 2020, she got involved in the education project "Mission Possible", with the aim to develop methodological materials for popularizing and teaching the subject of cybersecurity in Latvian schools.

E-mail: zita.lavrinovica@gmail.com

\section{Dr Barbara Mazur (ORCID ID 0000-0003-2527-2603)}

Lublin University of Technology, Poland

Professor, researcher at the Lublin University of Technology specializing in cultural aspects of management, corporate social responsibility and international business. Author and co-author of over 160 original research works, including five scientific monographs published in Polish and English. Member of the Praxeology Scientific Society and three international organizations: The European Business Ethics Network (EBEN), the Consumer Citizenship Network (CCN) and the Partnership for Education and Research about Responsible Living (PERL).

E-mail: b.mazur@pollub.pl

\section{Marta Mazur-Malek (ORCID ID 0000-0001-8546-4004)}

Graduated from the Warsaw School of Economics, Poland

Marta is obtaining a Bachelor's Degree in Management and Entrepreneurship. She has studied American culture in Poland and Germany, spa and wellness service design and management in Estonia and enterprise managementin Poland. Her academic interests are corporate wellness, wellbeing management and process management.

E-mail: mazur.malek@yahoo.com 


\section{Elina Saba}

BA School of Business and Finance, Riga, Latvia

Master's student. Bachelor's degree in communication science from Riga Stradins University. After working in client support for the private sector for over 10 years, she currently works for the public sector as a defence capability project manager's assistant. Her research interests lie in the field of cyber security, social engineering and trends in the development of communication.

E-mail: Saba.Elina@gmail.com

\section{Maris Saba}

BA School of Business and Finance, Riga, Latvia

Master's student. Bachelor of Science in Economics and Arabic from the United States Military Academy at West Point, New York. Maris currently focuses on cybersecurity management and its relation to state defence and military strategy.

E-mail: maaris.saba@gmail.com

\section{Muhammad Umer Shahid (ORCID ID 0000-0003-1084-9967)}

BA School of Business and Finance, Riga, Latvia

International doctoral student from Germany. Umer worked for 3 years as a lecturer at the University of Wah, Pakistan, and taught various management courses (HR, Entrepreneurship, OB, SCM). In doctoral studies, his research interest is in entrepreneurial networking and its various outcomes under varying institutional (formal \& informal) contexts. Currently, Umer is working with big data sets (Global Entrepreneurship Monitor, World Bank, World Value Survey, Index of Economic Freedom) and using multilevel modelling techniques for his research.

E-mail: umer.zai1988@gmail.com

\section{Jekaterina Sneidere}

RISEBA University of Applied Sciences, Latvia

Jekaterina Sneidere, Ms.oec.sc., has worked in the banking industry since 2001, holding various positions in areas such as investment banking, compliance, and finance.

E-mail: katya.schneider@gmail.com 


\section{Dr Tatjana Volkova (ORCID ID 0000-0002-7599-8720)}

BA School of Business and Finance, Riga, Latvia

Professor of Strategic Management and Innovation Management. Research interests: innovation management, strategic management, cybersecurity governance. Her research findings have been published in a number of peer-reviewed books and journals nationally and internationally and presented at numerous international conferences.

E-mail: Tatjana.volkova@ba.lv 


\section{Editorial Affiliation Details}

Dr Prof Tatjana Vasiljeva, Head of the Editorial Board (ORCID ID 0000-0002-64102239)

Latvia, RISEBA University of Applied Sciences, Meza Street 3, Riga, LV-1048, phone: +371 67500265, www.riseba.lv

Dr Assoc Prof Bella Butler, Editor (ORCID ID 0000-0002-5790-1745)

Australia, Curtin University, Kent Street, Bentley, Perth, Western Australia 6102, phone: +61 892669266, www.curtin.edu.au

Dr Prof Andrejs Cirjevskis, Editor (ORCID ID 0000-0002-0754-9712)

Latvia, RISEBA University of Applied Sciences, Meza Street 3, Riga, LV-1048, phone: +371 67500265, www.riseba.lv

Dr Prof Irina Sennikova, Editor (ORCID ID 0000-0001-6005-3946)

Latvia, RISEBA University of Applied Sciences, Meza Street 3, Riga, LV-1048, phone: +371 67500265, www.riseba.lv

Dr Prof Tatjana Volkova, Editor (ORCID ID 0000-0002-7599-8720)

Latvia, BA School of Business and Finance, K. Valdemara Street 161, Riga, LV-1013, phone: +371 67360133, www.ba.lv

Dr Prof Drahomira Pavelkova, Editor (ORCID ID 0000-0003-1399-6129)

Czech Republic, Tomas Bata University, nám. T. G. Masaryka 5555, 76001 Zlín, phone: +420 576038120, www.utb.cz 
Dr Prof emeritus Tonis Mets, Editor (ORCID ID 0000-0003-3972-5204)

Estonia, University of Tartu, Ülikooli 18, 50090 Tartu, phone: +3727375100 , www.ut.ee/et

Dr Prof Ole Gjolberg, Editor (ORCID ID 0000-0001-7175-8300)

Norway, University of Life Sciences, Universitetstunet 3, 1430 As, phone: +4767230000 , www.nmbu.no

Dr Daiga Kamerade-Hanta, Editor (ORCID ID 0000-0003-2019-3391)

United Kingdom, University of Birmingham, Birmingham B15 2TT, phone: +44(0)1214143344, www.birmingham.ac.uk

Dr Inna Kozlinska, Editor (ORCID 0000-0003-3341-3138)

The Netherlands, University of Groningen, address: PO Box 72, 9700 AB Groningen, phone: +3150363 9111, www.rug.nl

Dr Virginijus Kundrotas, Editor (ORCID ID 0000-0002-9549-4546)

USA, Adizes Graduate School, address: 1212 Mark Avenue, Carpinteria, Santa Barbara County, California, 93013, phone: +805 566 0742, www.adizes.com

Dr Prof Ulla Hytti, Editor (ORCID ID 0000-0003-1129-4473)

Finland, University of Turku, FI-20014 Turun yliopisto, phone: +358 294505000, www.utu.fi

Dr Prof Sean Patrick Sassmannshausen, Editor (ORCID ID 0000-0001-8265-2413)

Germany, Regensburg University of Applied Sciences, Pruefeninger Str. 58, 93049

Regensburg, phone: +49(0)94194302, www.oth-regensburg.de 
Dr Prof Arnis Sauka, Editor (ORCID ID 0000-0002-7708-4375)

Latvia, Stockholm School of Economics in Riga, Strelnieku Street 4A, Riga, LV-1010, phone: +371 67015800, www.sseriga.edu

Dr Prof Maryna Z. Solesvik, Editor (ORCID ID 0000-0002-6702-4643)

Norway, Western Norway University of Applied Sciences, Inndalsveien 28, 5063 Bergen, Norway, phone: +47 55585800, www.hvl.no 
Journal of Business Management, ISSN 1691-5348, Volume 19, 2021 is jointly published by

\section{- RISEBA \\ UNIVERSITY OF APPLIED SCIENCES \\ Busincss $\cdot$ Arts $\cdot$ Technology}

\section{RISEBA University of Applied Sciences}

Address: Meza Street 3, Riga, LV-1048, Latvia

Telephone: +37167500265

E-mail: riseba@riseba.lv

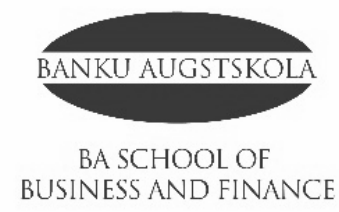

BA School of Business and Finance

Address: K. Valdemara Street 161, Riga, LV-1013, Latvia

Telephone: +37167360133

E-mail: info@ba.lv 